\title{
C W Doppler audiospectrum analysis in the iliac arteries
}

Citation for published version (APA):

Haeck, L. B. A. (1989). C W Doppler audiospectrum analysis in the iliac arteries. [Doctoral Thesis, Maastricht University]. Rijksuniversiteit Limburg. https://doi.org/10.26481/dis.19890914lh

Document status and date:

Published: 01/01/1989

DOI:

10.26481/dis.19890914lh

Document Version:

Publisher's PDF, also known as Version of record

\section{Please check the document version of this publication:}

- A submitted manuscript is the version of the article upon submission and before peer-review. There can be important differences between the submitted version and the official published version of record.

People interested in the research are advised to contact the author for the final version of the publication, or visit the DOI to the publisher's website.

- The final author version and the galley proof are versions of the publication after peer review.

- The final published version features the final layout of the paper including the volume, issue and page numbers.

Link to publication

\footnotetext{
General rights rights.

- You may freely distribute the URL identifying the publication in the public portal. please follow below link for the End User Agreement:

www.umlib.nl/taverne-license

Take down policy

If you believe that this document breaches copyright please contact us at:

repository@maastrichtuniversity.nl

providing details and we will investigate your claim.
}

Copyright and moral rights for the publications made accessible in the public portal are retained by the authors and/or other copyright owners and it is a condition of accessing publications that users recognise and abide by the legal requirements associated with these

- Users may download and print one copy of any publication from the public portal for the purpose of private study or research.

- You may not further distribute the material or use it for any profit-making activity or commercial gain

If the publication is distributed under the terms of Article $25 \mathrm{fa}$ of the Dutch Copyright Act, indicated by the "Taverne" license above, 
Promotor:

co. Promotor:

Beoordelingscommissie: Prof. Dr. J.M. Greep

Prof. Dr. P. Brugada

Prof, Dr. D.L. Clement

Dr. P.J.E.H. Kitslaar

Prof. Dr. S.H. Skotnicki

The financial support by Deckers (Leuven) for the publication of this thesis is gratefully acknowledged. 


\title{
C W DOPPLER AUDIOSPECTRUM ANALYSIS IN THE ILIAC ARTERIES
}

\author{
PROEFSCHRIFT
}

ter verkrijging van de graad van doctor aan de Rijksuniversiteit Limburg te Maastricht, op gezag van de Rector Magnificus, Prof. Dr. F.I.M. Bonke, volgens het besluit van het College van Dekanen, in het openbaar te verdedigen op donderdag, 14 september 1989 om 16.00 uur

door

LUC BERNARD ARTHUR HAECK

geboren te TIELT (B) in 1952 



\section{TABLE OF CONTENTS}

General Introduction: aim of the study

Part I Literature study

I. Atherosclerosis of lower extremities

I-1 Pathologic changes

I-2 Site of atherosclerosis

II. Physiology

II- 1 Pressure 9

II-2 Flow velocity profile $\quad 12$

II-3 Collateral circulation $\quad 15$

III. Doppler technique and its application to the aorto-femoral arteries $\quad 16$

III-1 History, definition $\quad 16$

III-2 Principle $\quad 16$

$\begin{array}{ll}\text { III-3 Signal processing } & 1.8\end{array}$

$\begin{array}{lll}\text { III-4 Emission of vitrasound } & 19\end{array}$

III-5 Application of CW audio spectrum analysis to the iliac and $\begin{array}{ll}\text { femoral arteries } & 22\end{array}$

III-5-1 Etiology of spectrum 22

III-5-2 Changes in the audio spectram 24

III-5-3 Detecting stenoses with the use of the audio spectrum 25

III-5-4 Parameters used in the diagnosis of atherosclerotic lesions 25

III-6 Conclusion $\quad 30$

IV. Biplane arteriography and pressure measurements in aortoiliac arteries $\quad 31$

IV-1 Biplane arteriography 31

IV-2 Pressure measurements $\quad 32$

IV-3 Discussion $\quad 33$

Part II Own Examinations $\quad 37$

V. Patients $\quad 37$

VI. Methods of examination $\quad 38$

VI-1 Examination of the patient 38 
W-2 Classification of Doppler spectra 38

VII. Equipment 43

WI-1 CW Doppler with audiomspectrum frequency analyser 43

VII-2 Arteriography and pressure measurements 44

VIII. Duata processing $\quad 47$

IX. Results 48

IX-1 The results when the Doppler audiospectra are recorded in the femoral arteries 48

IX-2 The results when the Doppler audiospectra are recorded in the liac $\begin{array}{ll}\text { artiteries } & 52\end{array}$

1X-2-1 Comparison with arteriography $\quad 52$

IX-2-2 Analysis of false positive and false negative results in arteriography $\quad 55$

IX $-2-3$ Comparison with pressure measurements 56

1X-2-3-1 Arteriography and pressure measurements 57

IX-2-3-2 Doppler tests and pressure measurements 59

IX-2-3-3 Analysis of false positive and false negative results in the combined pressure test 66

IX-2-3-4 Discussion $\quad 68$

IX-3 Evaluation of clinical parameters 71

IX-3-1 Thigh claudication/calf claudication 71.

IX-3-2 Femoral artery pulse $\quad 73$

IX-3-3 Femoral bruit $\quad 75$

IX-4 Evaluation of parameters derived from the Doppler audiospectrum $\quad 78$

IX-4-1 Reversed wave $\quad 78$

IX-4-2 Systolic peak $\quad 80$

General Discussion 81

$\begin{array}{lr}\text { Summary } & 89\end{array}$

$\begin{array}{ll}\text { Samenwating } & 93\end{array}$

$\begin{array}{ll}\text { References } & 97\end{array}$ 
Medical history, clinical examination and arteriography are methods providing adequate assessment of the severity of atherosclerotic disease in most of the patients requiring reconstructive vascular surgery. However, in part of the cases the rellative hemodynamic significance of the disease in the aortoiliac, femoropopliteal, and more distal arteries remains uncertain. Particularly the detection of functionally significant aortoiliac disease is an important problem, because it may lead to the failure of any more distal reconstruction. Therefore, in patients with combined disease it is important to obtain information about the patency of the aortoiliac pathway. As Brewster (1982) pointed out, $66 \%$ of his patients requiring surgery presents a multilevel occlusive disease.

The state of the arterial circulation can be judged clinically by palpation of the arterial pulse at different locations (femoral, popliteal, tibial arteries) and by listening to bruits, if any, over the arteries. These methods, however, are strongly subjective and frequently fail .

Several methods have become available to the inwestigator to examine the arterial circulation. The strain gauge plethysmograph and plethysmographs based upon other principles are at hand to investigate pulsation, and filling and emptying of the vessels in the extremities. In the early 1960 s the Doppler principle started to be used clinically. It allowed the physician to measure blood flow velocity and ankle pressure to determine ankle/arm pressure indices. The latter method is a good measure to diagnose or exclude claudication and to assess objectively the existence of vascular pathology. The method, however, fails to localize stenoses in the aortoiliac, the femoropopliteal pathway or both, and to accurately determine the severeness of the disease.

The Doppler signal or Doppler frequency shift is caused by the moving particles in the arteries. Doppler ultrasound can be emitted continuously (continuous wave, $\mathrm{CW}$ Doppler) or intermittently (pulsed Doppler). The signal received can be processed in various ways. One approach is to record the spectrum of frequencies as a function of time. Several parameters, as derived from the Doppler signal, were subject to investigations over the past 25 years. The main purpose was to develop methods to assess the sites and the extent of arterial diseases, and the hemodynamic implication of the lesion.

Camphell (1984) made a comparison between several methods to describe the Doppler signals obtained from the common femoral artery to diagnose aortoiliac stenosis. One of his conclusions was that conventional clinical assessment was the best method for detecting aortoiliac stenoses with a diameter reduction of more than $50 \%$. For less severe 
diseases the addition of vascular laboratory tests is helpful.

Kislaar (1982) used wavefom analysis of the CW Doppler signal recorded in the femoral artery to detect stenoses in the aortoiliac arteries with a diameter reduction of more or less than $50 \%$. His conclusion was the maximum reversed frequency and the duration of the systolic upslope of the femoral Doppler audiospectrum were the most useful signal parameters.

Other investigators used invasive methods, like pressure measurements, to dermermine the hemodynamic importance of aortoiliac stenosis. These pressure mexstrements were found to be accurate (Brener 1974, Brewster 1979, Thiele 1983), but are invasive and therefore not without risks. Verhagen (1985-1987) also used a femoral artery pressure test (FAP test). In this test two parameters were used: the femorobrachial pressure index at rest and the index gradient, i.e. the difference between the index at rest and the lowest index during postischemic reactive hyperemia. He used the clinical outcome of arterial reconstructions as the gold standard for evaluating the blood pressure criteria.

There were several reasons to perform the present study. At first, all studies previously performed on human limbs used the femoral artery as its site of examination. It is known that flow disturbances become normal at a relatively short distance distal to the stenosis, especially when the diameter reduction of the artery is limited (Reneman 1979). More accurate results could possibly be obtained by examining the iliac rather than the femoral arteries. Therefore, in the present study the Doppler signals were recorded in the femoral and in the iliac arteries to allow a comparison between the results obtained, when recording the signals close to the atherosclerotic lesion and further away from the site of disease. The iliac arteries were screened transcutaneously through the abdomen. A second reason was to develop a method which is not expensive and can easily be used in most vascular laboratories. CW Doppler instruments with audiospectrum analysis were used because they are easy to use. In this approach changes in the Doppler spectrum, as induced by flow disturbances due to the lesions, are detected. Using the experience in the vascular labotatory of the Catharina Hospital (Eindhoven) to detect stenoses in the carotid artery bifurcation with a CW Doppler system combined with spectrum analysis of the signal (Van Baalen 1987), we have tried to develop a technique to diagnose stenoses in the aortoiliac pathway.

The method aims at detecting stenoses with a degree of diameter reduction of less than $50 \%$. A diameter reduction of $50 \%$ seems to be accepted as a breaking point defining significant from non - significant lesions. The question can be raised as to whether this assumption is justified. In combined atherosclerotic diseases, it can be important to diagnose stenoses of a lesser degree of narrowing. Underestimating the importance of 
lesions with minor degree of stenosis can be the cause of failure of distal reconstructive surgery or clinical outcome. Experimental studies (Bendick 1982, Evans 1982) with direct CW Doppler examinations have shown that it is possible to accurately diagnose stenoses with lesser degrees of narrowing. Screening the iliac artery directly rather than obtaining the information from more distal arteries could provide more detailed information about stenoses with a lesser degree of narrowing.

In a prospective study on 25 patients (Haeck 1983) it became clear that about 5 different spectral patterns can be associated with flow disturbances related to differtent degrees of arterial narowing. In order to evaluate the accuracy of these patterns to diagnose lesions with different degrees of narrowing in the iliac pathway an extensive prospective study was started.

Biplane arteriography was employed as the gold standard. Using the Seldinger technique for arteriography it became possible to use the cathetter not onlly for contrast injections, but also to perform pressure measurements. This method was initially described by Brener (1974) and Brewster (1978). This invasive method could provide additional information about the state of the arteries under investigation.

In conclusion it was the aim of the present study to investigate whether - spectral analysis of the CW Doppler signal, as recorded in the iliac arteries, is an accurate method of diagnosing hemodynamically significant stenoses in the aortoiliac pathway;

- there is a difference between recordings made in the femoral and the iliac arteries, as far as the diagnostic accuracy of these stenoses is concerned;

- pressure measurements in the aortoiliac pathway add any additional information. 


$$
-6 .
$$




\section{PART I: LITERATURE STUDY}

\section{ATHEROSCLEROSIS OF LOWER EXTREMITIES}

\section{I-1 Pathologic changes}

It is beyond the scope of this dissertation to discuss the details of the etiology of atherosclerosis. Only a brief summary will be given about the most important vessel wall changes involved in atherosclerosis. According to Betz (1987) atherogenesis is multifactorial in etiology. The main processes, which occur within the vessel wall and lead to the formation of atheromas, are:

- Increased permeability of the arterial endothelium for macromolecules, such as lipids or lipoproteins.

- Inwasion of the subendothelial space by blood cells (granulocytes and monomuclear cellis)

- Migration of smooth muscle cells from the inner layer of the media into the subendothelial space forming tissue cushions and thereby stenosis of the arteries.

- Formation of abundant matrix material within the intima (elastin, collagen, glycosaminoglycans) by the myocytes. These deposits aggravate the stenosis. - Increased endocytosis of lipids by mononuclear cells and smooth muscle cells; formation of foam cell hyperlipidemia.

- Appearance of necrotic areas within the plaque when the proliferate exceeds a critical thickness. This results in deposition of callcium and mineralization of matrix material.

According to personal observations, while performing vascular procedures, it is surprising to see various types of arterial diseases. The arterial wall can be thickened and stiff and the lumen of the artery is smaller, but one has the impression that the endothelial surface is free of disease. On the other hand the arterial wall may have normal aspect, but the lumen of the artery is filled with debris, the endothelium must be the sick part of the artery. Also the question why with some patients there is a general involvement of the arteries, while with others the atherosclerosis is circumscribed and local, has not been answered yet .

\section{I-2 Site of atherosclerosis}

In a number of patients atherosclerosis is segmental in its distribution. It develops at major arterial bifurcations, in areas where the artery passes rigid structures, such as bone or ligaments (for instance Hunters chamnel for the femoral artery), and at places where an acute angulation of the artery is seen.

Only a limited number of studies describes the site of atherosclerosis. In this respect 
the work of Mamovic (1967) 1 sarticularly interesting. As shown in figure $I-1$ the arteral inwolvement can be distinguished in 8 patterns.

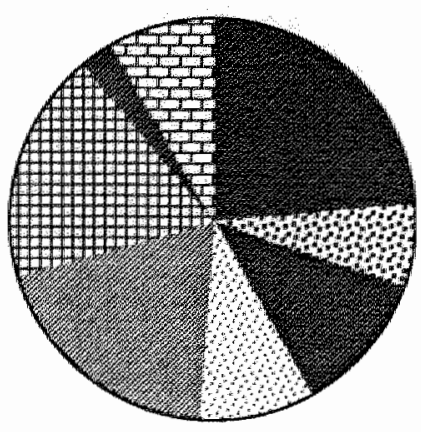

$23,7 \%$

I tibial anteries

$6.5 \%$

II popititeall artery

$111.9 \%$

Q IV femoro popitteal artery

$8.9 \%$

V ternoro- popliteal- tibial aa.

$19.5 \%$

EII $V=V$ and aortoilias aa.

$18,3 \%$

$V \| l=V$ and iliac aa

$3,0 \%$

VIII $=V$ aortoiliac aneurysm

$8.2 \%$

Fig. 1-1: Arterial inwolvemem in patients withou diabetes

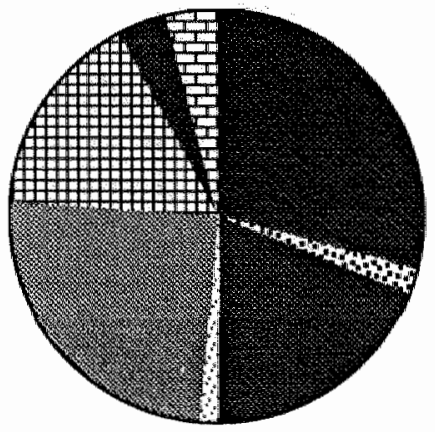

Fig. 1-2: Arterial involvemen in patients with diabetes

In the tibial-peroneal group, occlusion of the leg arteries alone occurred in 85 extremities (mean $26.5 \%$ ). Isolated femoropopliteal lesions primarly occurred in non-diabetic atherosclerosis while the lesion seemed to be initiated at the foramen of the aductor 
magnus.

Not only the site of atherosclerosis, but also the fact that the existence of diabetes has its influence on the site of sclerosis is important in arteriall diseases (figure 1-2).

\section{PHYSIOLOGY}

The dynamics of blood flow are a co-ordinate system of different major factors. The energy imparted to the circulatory system by the heart is manifested in potential energy (or pressure) and kinetic energy (or flow). The peripheral impedance is the ratio of the two forms of energy. Potential energy can be converted into kinetic energy, but represents only the potential of doing work and cannot be dissipated or lost. Energy losses can only occur with kinetic energy. Kinetic energy implies mass and velocity. Therefore, energy losses occurring in a fluid system must be related to the velocity of flow (Keitzer 1965). The velocity of flow can be detected by means of the Doppler principle.

Some physiological phenomena of blood flow are important when using Doppler signals. In this chapter some of these aspects will be discussed. $A$ brief discussion is given of:

- the flow partern in normal arteries, laminar flow along the arterial tree;

- the flow pattern in diseased arteries, flow disturbances and turbulence;

- the impact of collateral circulation.

\section{II-1 Pressure}

Instantaneous pressure values can be recorded at any place in the arterial system. The pressure pulse wave is rather characteristic for each site (see figure I-3). The factors influencing the shape of the arterial pressure curve are the force and the frequency of cardiac contractions, the elasticity and the dimensions of the major and medium-sized arteries, and the diameter of the arterioles, determining the peripheral resistance. The predominant cause of distortion of the pressure pulse wave shape is a reflection of the travelling pulse from branching points and the small peripheral vessels or arterioles (McDonald 1974). In normal arteries there is a pressure drop along the arterial tree that can be divided into five principal components: (Spencer - Arts 1984)
a. gravity
b. flow acceleration
c. viscous loss of Poiseuille
d. convective loss of Bernoulli
e. boundary layer loss 


\section{a. GRAVTTY:}

The effect of gravity is minmal in short sections of the circulation. One cannot compare the arterial pathway with the nomal in vitro laws of gravity. The circulatory system is a closed and supporting system, so gravity cannot shift the blood flow to a lower energy level. Gravity can change the flow by altering vascular resistance and capacitance (passively by changing position and reflectory by the carotid baroreceptors) (Badeer 1985).

\section{b. FLOW ACCELERATION:}

Flow acceleration is due to inertia of the fluid mass which requires a pressure difference to accelerate and decelerate the blood. The loss due to flow acceleration $(\Delta$ Pincr) is equal to

$$
\Delta \text { Pinert }=\lg d x / d t
$$

in which

$$
\begin{aligned}
& \nabla=\text { blood density, viscosity } \\
& 1 \quad=\text { length of flow segment } \\
& d v \quad=\text { rate of change of welocity } \\
& d t \quad=\text { change of time }
\end{aligned}
$$

\section{c. VISCOUS LOSS OF POISEUILLE:}

The drop in pressure along a flow channel, when the profile is constant, is only due to the viscous drag. The effect of viscous loss ( $\triangle$ Ppois) is stronger in small-diameter vessels and longer channels and is equal to $\Delta P$ pois $=8 \mathrm{P} 1 / \mathrm{r} 2 . \mathrm{V}$ mean

$$
\text { in which } \begin{aligned}
r & =\text { radius of the channel } \\
\text { Vmean } & =\text { mean velocity of flow }
\end{aligned}
$$

This is illustrated in figure $\mathrm{I}-4$

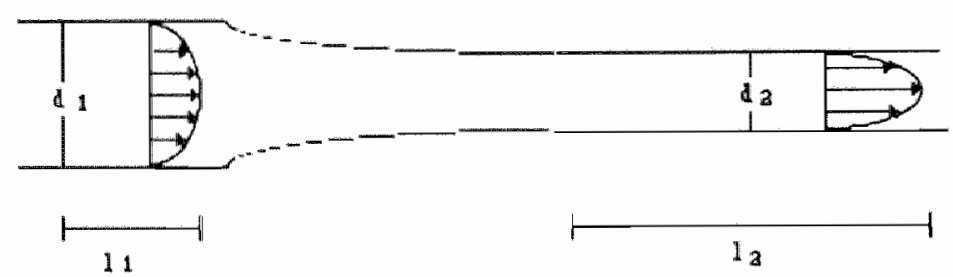

Fig 14: Poisenille viscous losses. Effect of viscosity on pressure drop along constant flow channels with parabolic profkes. 


\section{d. CONVECTIVE ACCELERATION LOSS OF BERNOULLI:}

As the flow stream enters into a stenotic segment of a flow channel, velocity has to increase to maintain the same volume flow in the stenotic and upstream segment (fig $1-5$ ).

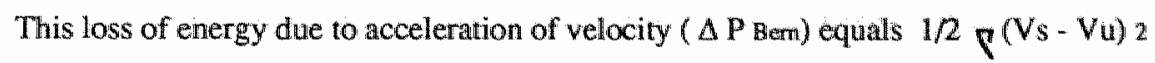
in which

Vs $=$ velocity within stenosis

$\mathrm{Vu}=$ velocity immediately upstream

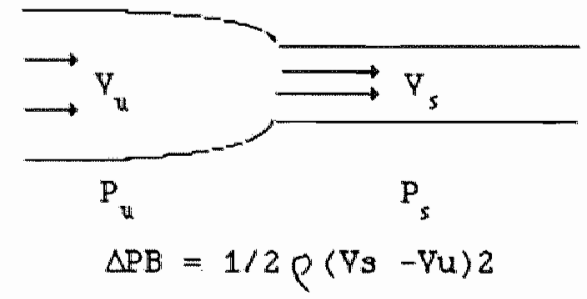

Fig. I-5: Bernoulli convective acceleration loss. Relationship between the pressure drop, due to spatial acceleration of blood entering a stenosis, and blood density, velocity within the stenosis (Vs) and the velocity immediately upstream (Vu). $P S=$ pressure within the stemosis and $P u=$ pressure upstream. The pressure drop will be represented by $P$ s $-P u$.

\section{e. BOUNDARY LAYER LOSS:}

As we follow the flow stream from the stenosis entrance along a stenotic channel, there is a gradual return from the flattened profile, produced by Bernoulli's convective acceleration, to a more parabolic profile (figI-6). The change in shear rate, producing this modification in profile, produces a pressure drop which is related to the length of the stenotic segment as well as its radius. This loss is added to the Poiseuille viscous loss and equals

\begin{tabular}{|c|c|c|}
\hline$\Delta P_{\text {sh }}=0.24$ & $V_{2} \partial(I) / r$ & \\
\hline in which & $\partial(1)$ & $\begin{array}{l}=\text { change in shear rate along the length } \\
=\text { radius }\end{array}$ \\
\hline
\end{tabular}

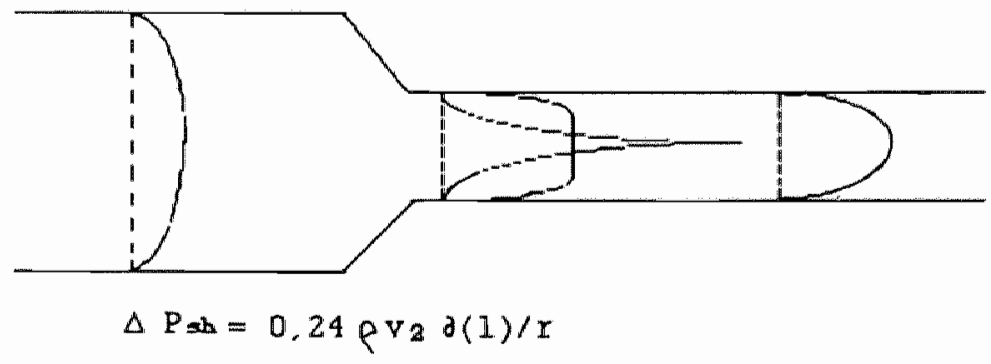

Fig. I-6: Boundary layer loss. Changing velocity profile from flattened type of entrance of stenosis towards a parabolic type along the length of the stenosis. 
1) 2 Flow welocity profule:

An instamaneous flow tracing can be derived at any site along the arterial system analogous to the pressure pulse wave on which it depends (fig. 1-3). The same mechanismis, which change the shape of the pressure pulse, can be considered to change the shape of the instantaneous flow curve when travelling the arteries. Whille the pressure pulse wave increases, the flow pulse wave progressively decreases in amplitude towards the periphery.

The shape of the front of all the velocity vectors across any diameter of the vessel is called the welocity profile and represents the velocity distribution over the cross-sectional area of a blocd vessel. With pulsatile flow, a parabolic profile is never really attained and certainly not in the complicated, branching and tapering conduit of the human arterial system, where the entrance lengths are relatively short. The profiles have a continuous changing shape during each cardiac cycle, approaching a parabolic configuration at one moment and being nearly flat at other moments. (Reneman, Hoeks 1985, 1986)

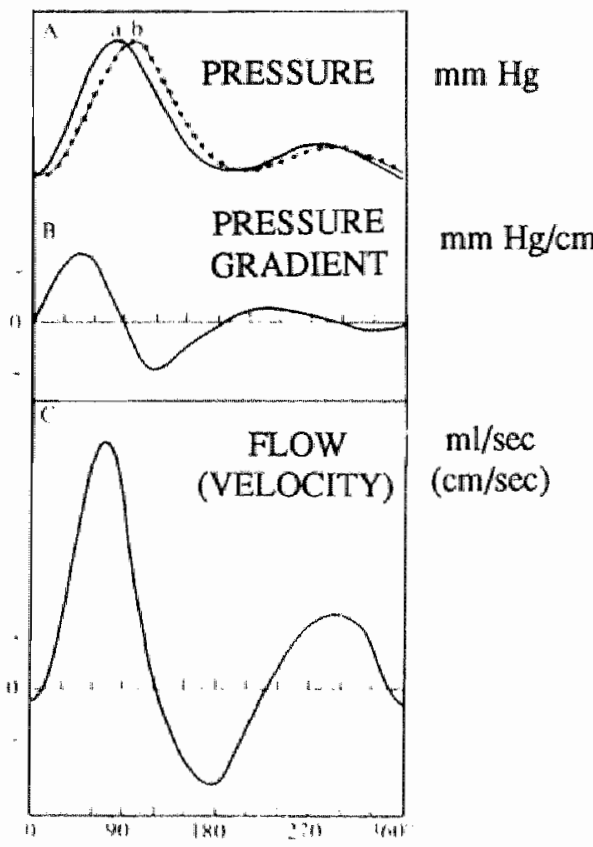

Fig. I - 3: Pressure and flow velocity curve of a normal femoral artery representing one cardiac cycte. A. Two pressure waves recorded a short distance apart (a. upstream, b. downstream). $B$. The pressure gradient derived by substracting the pressure at $b$ from that at a divided by the distance $a-b$. C. Flow (velocity) pulse wave resulting from the phasic positive and negative pressure gradients. Notice the phase difference be rween pressure and flow. (adapted and redrawn from MCDONALD, D.A.) 
If downstream of a stenosis the channel gradually widens so that tow disturbances do not develop and laminar flow is preserved, the Bernoulli pressure drop is regained downstream, and only the viscous losses produce the difference in $\mathrm{pl}$ and $\mathrm{p} 3$ (see figure 1 -7). Usually flow disturbances develop downstream to a stenosis because abrupt widening nearly always exists distal to such orifices.
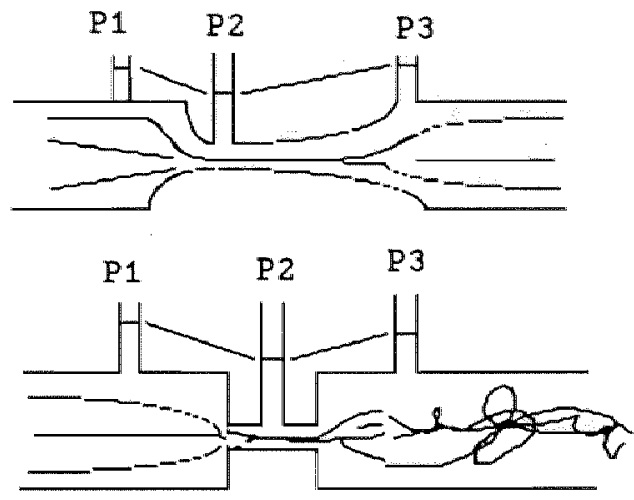

fig. 1-7: Two types of segmental stenosis. Above: the theoretical non-turbulent, tapered outlet allows recavery of the Bernoulli pressure loss. Below: The usual abrupt outlet produces turbulence where the Bermoulli pressure drop is lost in theat energy and nol recovered.

In these situations the pressure loss (p1-p2) is not regained. Those situations are to be found in human diseased arteries. In steady non-pulsatile flow situations (Barnes 1980) pressure gradients do not develop until the radius of the conduit reaches a critical value. The degree of vessel narrowing required to produce a detectable pressure gradient or reduction in blood flow is called the critical stenosis (May 1963). However the human blood flow is not steady, but pulsatile. The answer to the question whether a stenosis becomes significant in producing a pressure gradient is not answered by giving a uniwersal percentage of diameter reduction. It is entirely dependent on the state of the vessel tree, the shape of the stenosis, the pressure, the cardiac state of the patient and the peripheral resistance. The pressure drop across a given stenosis is proportional to the flow across the narrowing, which explains why relatively insignificant stenoses at rest may be associated with significant pressure gradients during increased flow associated with exercise. Unfortunately, the theory of a "critical stenosis", as proposed by May and co-workers, is not fully appropriate in human wessels because: 
- the changes observed with a graded stenosis in a rubber tube or the anteries of the dog (May 1963 ) may probably not be axtrapoldted to man with intimal disease of varying degree (schullz 1967);

- the diserased antery of the human exhibits changes not only at the intimal surface, but also in the mechanical propenties of the wall itself (Schult 1967-Flanigan 1977);

- wide vatiations in peripheral resistance cannot adequately be controlled in experments (j)ilanigan 1977).

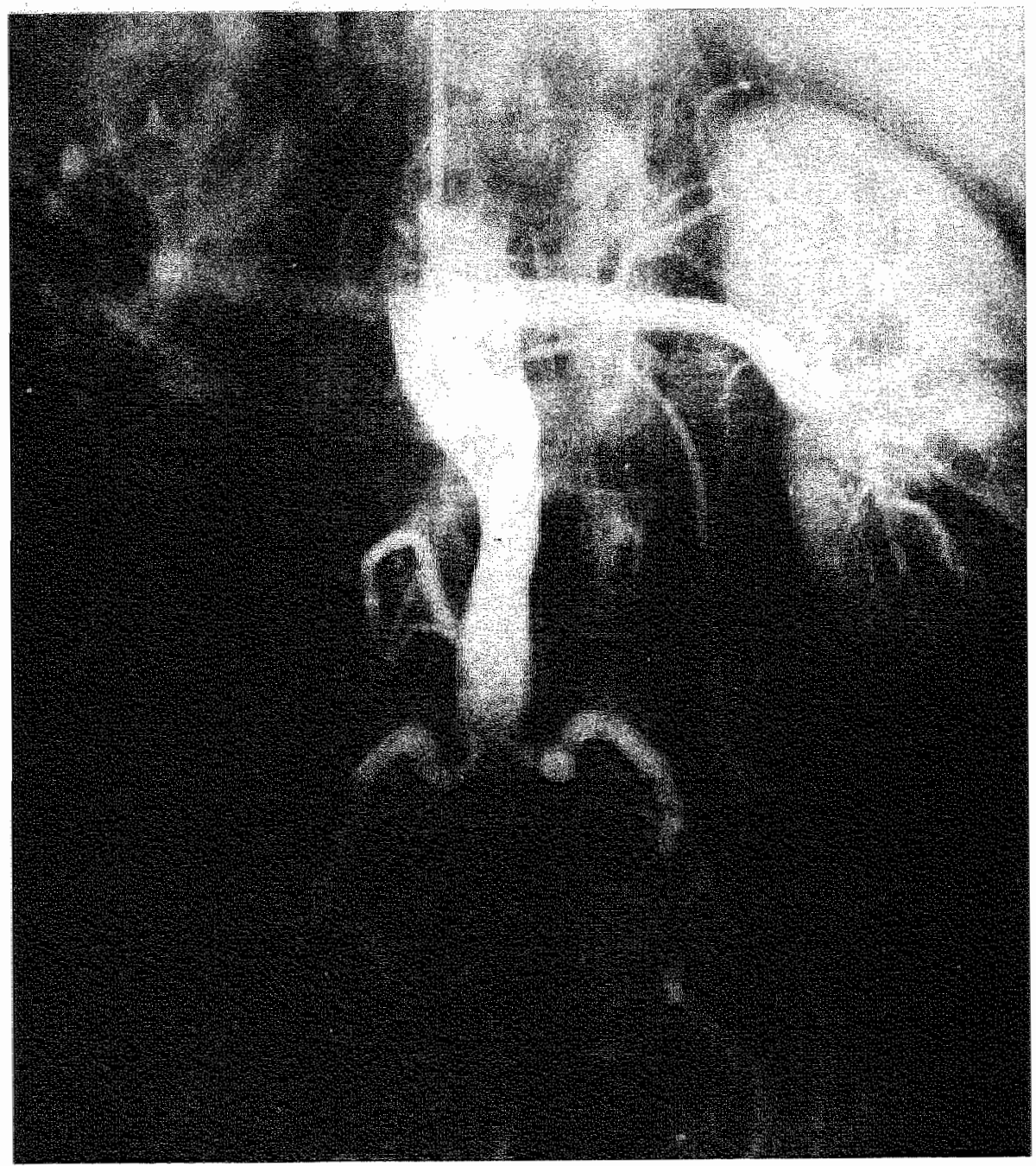

Fig - - 6: Occhurom of the dimal anta. Hyperplasia of two lumbar arteries. Important collateral flow. 
II - 3 Collaterall circulation:

The vital importance of the collateral circulation is best illustrated by presenting the history of a patient with total aortoilac obstruction. As shown on the arteriogram /fig. I -6) a total obstruction is bypassed by the collateral circulation with filling of the profunda femoral arteries on both sides. In this relatively young patient ( 47 years old) the only complaint is claudication accurring after 300 meters. Both anklle/am indices at rest were 0.35 .

Indeed, the arterial obstruction is compensatorily bypassed by the collateral circulation. The stimulus for development of such collaterals may be the abnormal pressure gradient across the collateral bed as a result of the main arterial obstruction, or the increased flow velocity through the collateral vessels (John 1961). Clinically this compensatory phenomenon is correlated to an improvement in pressure gradient and increased flow during exercise programs for arterial occlusive disease (Barnes 1980).

Functionally one can divide the collateral bed into stem arteries, midzone collaterals, and re-entry arteries (see figure 1-9). Most of these vessels are pre-existing pathways that enlarge when a stenosis or an occlusion develops in the parallel main arterial supply (Sumner 1984). The resistance of the collateral bed is almost fixed, except for gradual dilatation. In contrast, the peripheral run-off bed has a generally high, but quite variable resistance. The acute decrease in collateral resistance that occurs in response to exercise in the peripheral run-off bed, is rather small and of relatively little consequence in the collateral bed. The resistance of the collateral bed al ways exceeds that of the major artery whose function it has replaced.

The resting blood flow across the thigh has a large pulsatile component and a low mean flow component, and is associated with an insignificant pressure drop. With exercise the peripheral resistance decreases and flow across the segmental vessels increases up to a tenfold level, again with little pressure drop. With arterial occlusive disease the segmental resistance increases, but resting blood flow is normal as a result of a compensatory decrease in peripheral vascular resistance. The increased segmental resistance results in a reduction of the pulsatile component, and is associated with an abnormal pressure drop across the thigh. With exercise the peripheral resistance further decreases, but its capacity to do so is limited by the compensatory decreased resistance at rest and the limitations by the stenosis and the collateral resistance, so that exercise flow is lower than normal. 


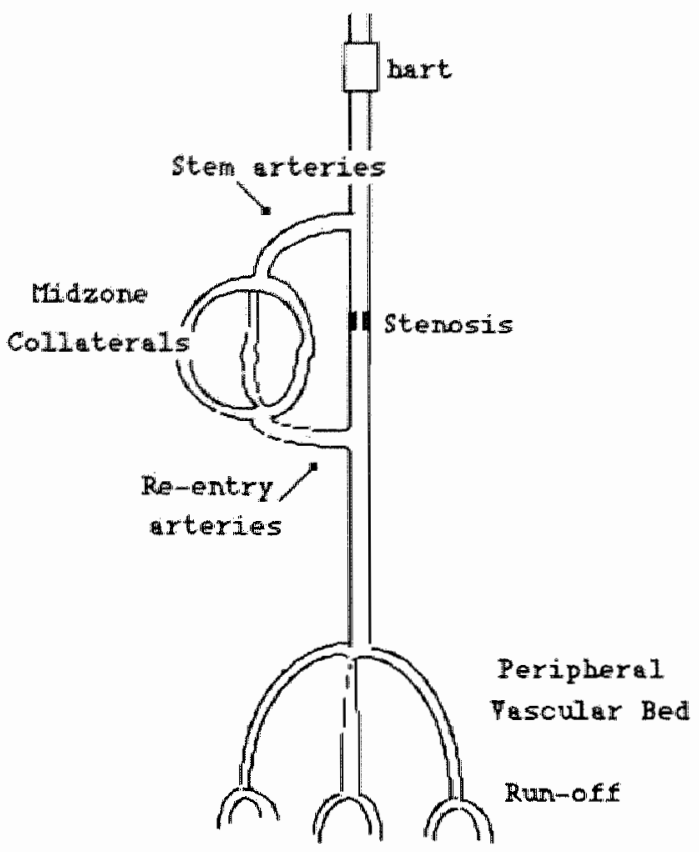

fig. 1-9: Diagram of the circulatory system

\section{DOPPLER TECHNIOUE AND ITS APPLICATION TO THE AORTO-FEMORAL} ARTERIES.

III-1 History, definition:

In 1842 Christian Doppler at first described the Doppler effect for starlight. In the late fifties and early sixties, this idea was applied to record flow velocity of fluids in the experimental work of Franklin (1961), and several Japanese investigators (Satomura 1960, Kato 1962). Since then, severil authors have applied this principle to record blood flow velocity. The Doppler effect can be described as follows. If a signal with a certain frequency is emitted, it will be back-scattered by solid structures. If these structures are moving objects, then the back-scattered signal is shifted in frequency. The difference between the emitted and back-scattered frequency is the Doppler frequency.

\section{III-2 Principle:}

In Doppler flowmeters a beam of ultrasonic waves (at $\mathrm{MHz}$ level) is transmitted from a vibrating crystal, penetrating diagonally through the vessel wall into the 
bloodstream. Some of the ultrasonic power is backscattered by the various structures in the body and received by another or the same crystall. The transducer crystals are mounted in a probe. Since ultrasound at the $\mathrm{MHz}$ level cannot be transmitted through air, acoustic gel is applied between the crystals and the skin to improve acoustic coupling (fig I-10).

Ultrasound backscattered from particles in the blood stream, mainly the red cells, is shifted in frequency by an amount proportional to the velocity of these particles. This frequency shift (the Doppler shift $=\mathrm{fd}$ ), which is retrieved by mixing the transmitted and received signals, is in the audio range and equals:

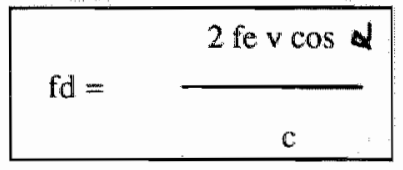

in which $\mathrm{fe}=$ emission frequency, $\mathrm{v}=$ velocity of the particles, $\alpha=$ the angle between the transmitted sound beam and the direction of the velocity of the particles, and $c=$ the velocity of sound in the medium (approx. $1560 \mathrm{~m} / \mathrm{s}$ ).

The Doppler signal does not contain one single frequency, but a spectrum of frequencies (the Doppler spectrum). The frequency distribution depends on factors such as unequal distribution of the red blood cell velocity over the cross-sectional area of the vessel, variations in the blood cell interspace, and divergence and non-uniformity of the sound beams, resulting in variations in the angle of interrogation when the red blood cells are passing the ultrasonic beam.

The amount of power received at the crystals is determined by the amount of backscattering from the red blood cell plasma interface and the quantity of sound absorption by the tissues. Both the amount of backscattering and the quantity of absorption increase at higher emission frequencies. The higher the emission frequency the lower the penetration depth, but the better the ratio of power backscattered by particles in the blood and the power reflected by targets like vessel walls and tissue interphases. When the effects of reflection and absorption are combined, the backscaltering from blood at a given distance from the transducer is strongest at a particular frequency.. For investigations of deeper vessels like the descending aorta and the iliac arteries, an emission frequency of 2-4 MHz was found as the most appropriate one, while with investigation of more superficial vessels, like the pedal arteries, the best results are obtained with frequencies in the range berween 5 and $8 \mathrm{MHz}$. The higher the number of red blood cells moving in the ultrasonic beam, the higher the received Doppler power. The received signal contains power backscattered from the red blood cells as well as from the vessel wall. The signals induced by lateral wall motion are low in frequency, but high 
in anplitude. Their ampliude is approximately thirly times higher than that of the signals induced by moving red blood cells because the vessel wall-blood interface is a much better reflector than the red cell-blocd interface.

\section{II- 3 signal processing:}

\section{III-3-1 Iritroduction}

Origunally in Doppler fowmeters the received signal was processed to an analog tracing, representing the cross-sectional average velocity as an instantaneous function of time. In this approach, however, valuable information present in the Doppler signal is ignored. This information is retained when audio spectrum analysis is used to analyse the received Doppler signal.

\section{III-3.2 Andlog signal processing}

A simple method of retrieving the Doppler signal is mixing the transmitted and the received signals. This demodulation technique has the disadvantage that no information is obtained about the direction of blood flow (non $\times$ directional system). In directional systems a more complicated demodulation technique is used. In this technique the received signal is demodulated with two signals at the transmitter frequency shifted $90^{\circ}$ in phase with respect to each other, resulting in two Doppler signals wich are $90^{\circ}$ out of phase. The sign of the phase shift between both signals indicates the sign of the frequency shift, i.e. the direction of blood flow. This demodulation technique gives a bidirectional velocity output, but interference between forward and backward flow cannot be prevented. Separation of positive and negative Doppler shifts, and hence between forward and backward flow, can be achieved with single side-band demodulation. Then the presence of backward flow can be assessed when the net flow direction is antegrade and contaminating venous flow signals can be recognized when measuring arterial blood flow velocity. Adding these flow signals, however, is only allowed when at least one of the outputs is zero. In order to diminish the influence of wessel wall motion signals and noise beyond the Doppler frequency band, the output of the demodulator is passed through a bandpass - filter.

Determination of the mean frequency of the Doppler spectrum and conversion of the signal into an analog signal was usully performed with a zero-crossing meter. The output is an analog woltage proportional to the number of zeno-crossings per unit of time. To diminish the counting of zeromcrossings unrelated to blood flow velocity the comparator voltage of the Schmitt-trigger is set at such a level that the zero-crossing meter will not be activated by low level signals (e.g. noise). The analog tracing obtained with this technique approximates the awerage velocity as an instantaneous function of time. A zero flow 
reference can easily be obtained by disconnecting the input to the signal processing system. The zero-crossing meter does not exactly measure the mean frequency of the Doppler spectrum, corresponding to the average velocity, bur a value higher that the mean Doppler frequency (Peronneau 1970). This systematic error depends on the shape and the width of the Doppler spectrum; the broader the spectrum with respeet to its average frequency, the larger the error. The zero-crossing meter appears to be accurate only for a single frequency or a relatively narrow frequency spectrum.

An additional disadvantage of zero-crossing meters is that the output entor is only negligible if the level of the audio signal exceeds the noise level at least 10 times. Proper adjustment of the threshold of the zero-crossing detector is required to prevent shifting of the instantaneous velocity tracing from the zero-line. Another disadvantage is that the output of the zero-crossing meter becomes unreliable if high amplitude low frequency components, induced by vessel wall motion, are present in the Doppler signal. To reduce the noise contribution and vessel wall motion artefacts, a bandpass filter is used which limits the frequency range of the audiosignal albeit at the cost of low and ligh velocity information (Reneman 1973). The upper frequency limitation can be a problem, especially in stenotic regions.

Valuable information, present in the Doppler signal, is eliminated in the analog tracing technique. Therefore, the use of audio spectrum analysis is preferred in CW Doppler systems. Audiospectrum analysis yields insight into the flow distribution and, hence, into the disturbances of this pattern as induced by atherosclerotic lesions.

\section{III-3-3 Audio spectrum Analysis}

As mentioned before, a Doppler signal does not contain one single frequency, but a spectrum of frequencies. Doppler spectrum analysis produces time-dependent sonograms in which frequencies are given as an instantaneous function of time. The intensity of the pattern represents the amplitude of the frequencies, indicating the number of blood. particles moving at a given velocity.

The method of digital frequency analysis most widely used is the fast Fourrier transform, a method of analysing periodic signals to assess their frequency content. This method is a true transform in that the method converts the function from time to frequency domain. The result may then be subjected to an inverse conversion to restore the original function. The magnitude of the function in the frequency domain is the spectrum. The display itself is in terms of time and frequency coordinates with magnitude displayed as gray-scale density (Strandness jr. 1985)

With some experience examinations with audio spectrum anallysis, especially when recorded with CW Doppler systems, are easy to perform. Differentiation between arteries 
is exsy to make, not only because the received Doppler spectrum is dependent on the number of red blood cells moving in the ultrasonic beam, but also because different arteries have different configurations as far as their spectrum is concerned.

\section{III-4 Emisgion of ultrasound}

In Doppler instruments ultrasound can be emitted continuously (CW Doppler) or intermittently (pulsed Doppler)

\section{III-4-1 CW Doppler systems}

In CW Doppler instruments the ultrasonic beam is usually transmitted from one crystal and the backscattered ultrasound received by another one (fig I-10). These systems are easy to build and to operate, but wessel wall motion artefacts are often difficult to eliminate, at leasit without simultancously eliminating the signals from blood flowing at low velocities. The high amplitude low frequency signals due to lateral wall motion strongly affect the shape of the frequency spectrum and therefore the accuracy of the mean welocity determination with the zero-crossing meter. Vessel wall motion signals can even mask the presence of high velocity information, necessitating additional attenuation at the lower end of the bandpass filter. This masking phenomenon is seen in analog signal processing with zero-crossing meters (Reneman 1973) as well as in audio spectrum analysis (Reneman and Spencer 1979).

CW Doppler instruments are easy to operate and they are inexpensive. The maximum frequency that can be detected unambiguously with these systems is theoretically unlimited. This is especially important when velocities are recorded within the stenosis to estimate the degree of artery narrowing (Spencer-Reid 1979). Velocity recording within a stenosis is rather easy because of the relatively wide ultrasound beam in CW systems.

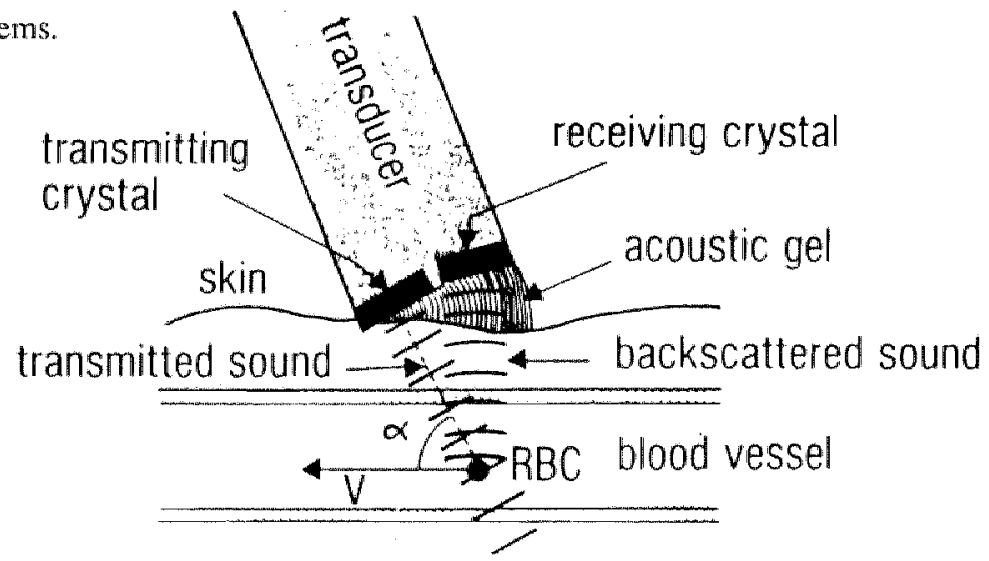

Fig. 1 - 10: The principle of $C W$ Dopple flowmetry. The arrow indicates the flow velocity (V) direction. $R B=$ red blood cell and $\boldsymbol{r}=$ the angle between the transmitted sound beam and the direction of flow fafter Reweman ef al. 1979). 


\section{III-4-2 Pulsed Doppler systems}

In pulsed Doppler flowmeters uswally one single crystal is used; alteriately operating as transmitter and receiver. The crystal receives the backscattered signals from the red blood cells and the vessel wall during the interval between pulses. In pulsed Doppler systems, single-channel and multi-channel systems can be distinguished.

Single-channel instruments.

In single-channel pulsed Doppler systems an electronic gate allows selection of scatterings either from the vessel wall or the red blood cells at a given distance from the transducer (see fig $\mathrm{I}-11$ ). This makes it possible to determine the mean velocity as an instantaneous function of time in a small sample volume at warious sites within an artery, thus avoiding contamination of the desired signal by unwanted signals like those from vessel walls and veins.

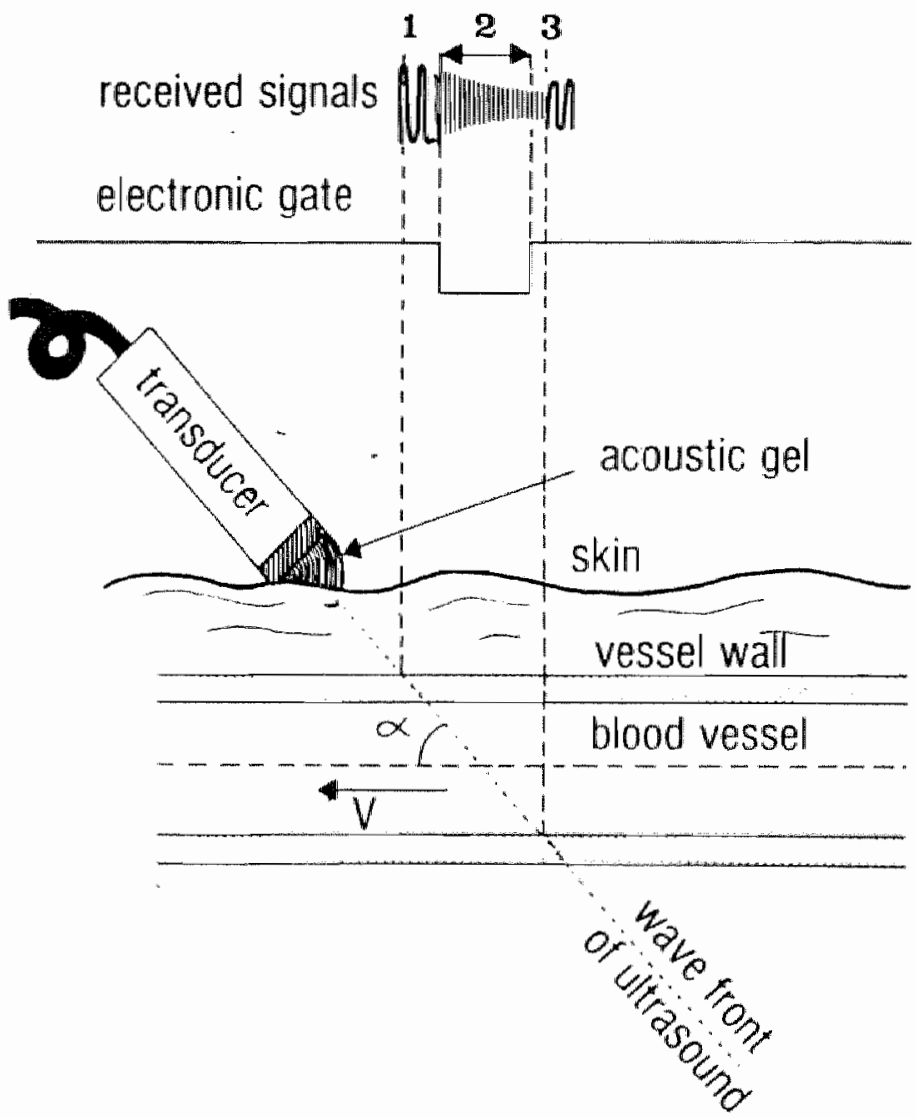

Fig. I - II: The principle of single channel pulsed Doppler flowmetry. The arrow indicates the flow direction. $I-3=$ ultrasonic power reflected from the anterior and posterior wall of the vessel, respectively. 2 = ultrasonic powe back-scattered from the red blood cells. The electronic gate is so adjusted that mainly the signal wich contains the flow velocity informanion is processed (after Rememan and Spencer, 1979). 
In principle, with single-channel pulsed Doppler systems the velocity profille can be determined. With these systems, however, the velocity as an instantaneous function of lime during one cardiac cycle can only be determined at a single site within the vessel. Therefore, synthesis of velocily profiles during a cardiac cycle requires that the instantaneous velocity signals at warious sites in an artery are assessed during consecutive heart beats. This limits the applicability of these systems in the diagnosis of peripheral artery diseases because in the vicinity of stenotic lesions the velocity profile was found to change locally during one cardiac cycle (Wille 1979). Besides, the positioning and maintenance of the sample volume at the site of interest requires some skill. This can be overcome by combining a single-channel pulsed Doppler with a B-mode imager.

Multi-channel instruments.

Multimchannel pulsed Doppler systems that have the ability to detect simultaneously and instantaneously velocities over the full range of interest have been developed. With these systems the velocity profille can be recorded on-line at discrete time intervals during one cardiac cycle (Anliker 1978, Brandestini 1978, Hoeks 1981, Reneman 1986). Concerning peripheral vascular diseases, the multi-channel pulsed Doppler systems can record flow patterns in two arteries simultaneously, e.g. at the deep and superficial femoral artery (Reneman 1986). With the use of these systems, diseases in the femoral artery can accurately be diagnosed over its full length by assessing parameters as velocity transit time and damping factor (Bruins Slot 1981).

III-5. Application of CW audiospectrum analysis to the iliac and femoral arteries.

\section{TII-5-1 Etiology of spectrum}

In a Newtonian fluid, the velocity profile at a cross-section of a steady laminar flow is known to be parabolic, provided that recording is made beyond the entrance length. The velocity spectrum is homogeneous from zero to the maximum velocity at any instant (Nimura 1974). In normal large human arteries the velocity profile is flattened (plug flow) rather than parabolic (Reneman 1985,1988).

The regular outline of the sonogram indicates that flow is laminar. The outline shape is smooth and pulstitie (Evans 1982). The tendency of frequencies to concentrate near the maximum frequency suggests that red blood cells tend to travel near the maximum which is representative of plug flow. But even under ideal circumstances there may be significant variability in the shape of Doppler waveforms, and this is an important consideration in the interpretation of spectra (Campbell 1984). 


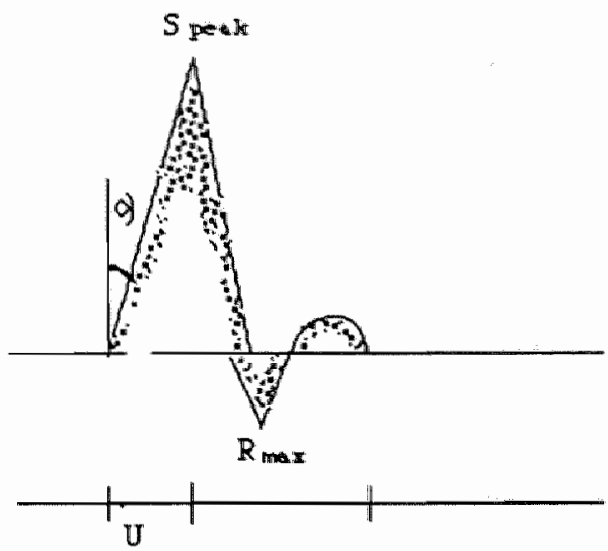

Fig 1-12: Diagram of a normal audiospectrum of ant iliac artery.

In figure 1-12 a normal Doppler audiospectrum is schematically presented. It consists of three waves:

- a forward, systolic wave. Most of the frequencies are found near the maximum frequency (the envelope of the spectrum). A normal systolic wave has a peak (we will call it Speak). A specific rise-time can be distinguished, being the time interval between the onset and the peak forward frequency of the waveform. Other investigators call it acceleration-time (Nicolaides 1979) or upslope (U) of the systolic deflection (Kitslaar 1982). Another parameter of the systolic slope is the angle of the upslope (alfa). Only Johnston (1977) paid attention to this parameter. If the angle between the Doppler probe and the axis of blood flow is changing from $60^{\circ}$ towards $0^{\circ}$, the amplitude of the wave increases, although the shape remains unchanged (see figure I-13).

- a reversed wave. In a normal arterial flow the heart beat causes a periodic propagation of the blood. Each beat ends with relaxation in diastole. The reversed wave appears in a more pronounced way in the middle part of the artery (Nimura 1974). The reversed wave is not only a result of a reflection from the periphery, but also of the compliance of the vessel wall.

The onset of the reversed wave in the audiospectrum generally occurs at the end of the forward wave. We have measured the maximum peak reversed wave, and call it Rmax. In some cases the reversed wave is minimal. As mentioned before, the reversed wave can be missed due to the use of low bandpass filters.

- a second forward wave or end diastolic velocity, seen mostly in young patients, is considered to be due to the nature of the arterial compliance. Recently Kohler (1987) found a correlation with the pressure gradient in experimental canine aorta models, but not 
in retrospective a data from human iliac stenoses.

- the window phenomenon. As described earlier the distribution of frequencies in the awdiospectrum has a maximum along the upper border. During the systolic wave a relatively clear area is created under the outline of the velocity waveform, and is called the window. If the spectrum broadens, the systolic window will disappear.

This window phenomenon is of great value in detecting stenoses in the carotid arteries using both continuous wave (Barnes 1976, Van Baalen 1987) and pulsed Doppler systems (Breslau 1981). The window is used as an additional parameter to detect stenoses in the aortoiliac pathway, as will be discussed later.

\section{III-5-2 Changes in the audio spectrum :}

Disturbances in flow are translated in a change of the audio spectrum. When a sonogram is recorded distal to a stenosis, the trace appears to be much more damped. A sonogram becomes damped when there is a decrease in peak to peak amplitude. The ouline shape usually retains the smoothness found in the healthy situation (Evans 1982). A sonogram recorded at the outlet of a stenosis displays features expected in disturbed How, such as spectral broadening, loss of concentration of the frequencies near the maximum frequency and an irregular outline of the sonogram (Reneman 1985, 1986). Turbulence is produced in some cases of stenosis. Then an irregular outline of the sonogram and a more or less even spectral distribution of the frequencies is seen. In turbulence the Bernoulli pressure loss is not regained (fig 1-7). The fluid particles show an acceleration through the stenosis (Clark 1980). This acceleration can be seen in the ${ }^{t}$ velocity spectrum. In disturbed flow and turbulence there is a wide variation in velocity of the different blood particles at one time. This leads to dispersion of frequencies. The so -called outline of the spectrum disappears and the spectrum broadens.

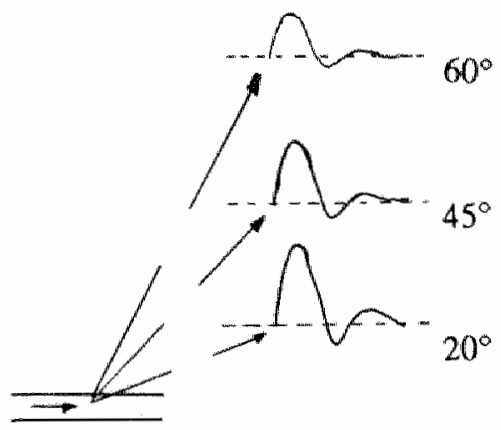

Fig. 1. 13: As the angle between the Doppler probe and axis of blood flow is changed towards $0^{\circ}$, the amplinde of the wave increases, although the shape remains unchanged (Johnston 1977 ). 
III-5-3 Detecting stenoses with the use of the audio spectrum:

It is possible to detect stenoses using the sonogram, but it is not as evident as theoretically presumed. As mentioned before there is an important difference in the interpretation of the waveforms.

In Bendick 's experimental work on dogs (1982), stenoses with $20 \%$ to $50 \%$ diameter' reduction can be detected by comparing the peak systolic frequency at the site of the stenosis with that proximal to it. For greater $\%$ of stenosis ( $>50 \%$ diameter reduction) turbulent flow patterns and significant spectral broadening were noted with a gradual decrease in the peak frequency ratio.

The audiospectrum returns to nomal at a relatively short distance from a stenosis (Evans 1982). Signals recorded at sites $1 \mathrm{~cm}$ or more distal to a stenosis experimentally obtained in the infrarenal aorta of mongrel dogs, were not significantly different from proximal spectra until the stenosis exceeded a $45 \%$ diameter reduction (Bendick 1982). Reneman and Spencer (1979) found for the carotid arteries that the flow distribution normalized $3-4 \mathrm{~cm}$ downstream of a stenosis with $50-60 \%$ diameter reduction. Also Giddens (1976) found this relatively rapid disappearance of flow disturbances in the descending aorta of dogs. We may assume that these observations also hold for the iliac and femoral arteries.

In this light it is important judging the aortoilliac diseases to screen the arteries as closely to the site of the lesion as possible. Therefore, a transabdominal approach is preferred rather than a more peripheral one, for example, by making recordings on the femoral artery. In order to perform this transabdominal examinations the use of Doppler instruments with relatively low emission frequencies will be necessary. The lower the emission frequency, the higher the penetration depth, but at the cost of loss of power of the reflected signal. But even with low emission frequencies it is possible to obtain a signal of sufficient quality.

111-5-4 Parameters used in the diagnosis of atherosclerotic lesions:

Different parameters, derived from the Doppler signal, have been used in the literature to diagnose atherosclerotic lesions. We will discuss the following indices: pulsatility index, damping factor, transient time, Laplace transform, rise time ratio, height width index, half recovery time and power frequency spectrum analysis.

1.PULSATILITY INDEX (PI):

Gosling (1971) gave the clearest definition of pulsatility index. He defined the PI as the total oscillatory energy in the flow-welocity waveform divided by the energy of the mean forward flow welocity during the cardiac cycle. For a matter of practical use the PI can be measured as the sum of peak forward flow and the maximal reversed flow, divided 
by the mean forward tow (obtained by special methods of processing the audiosignal), see figure $1-14$.

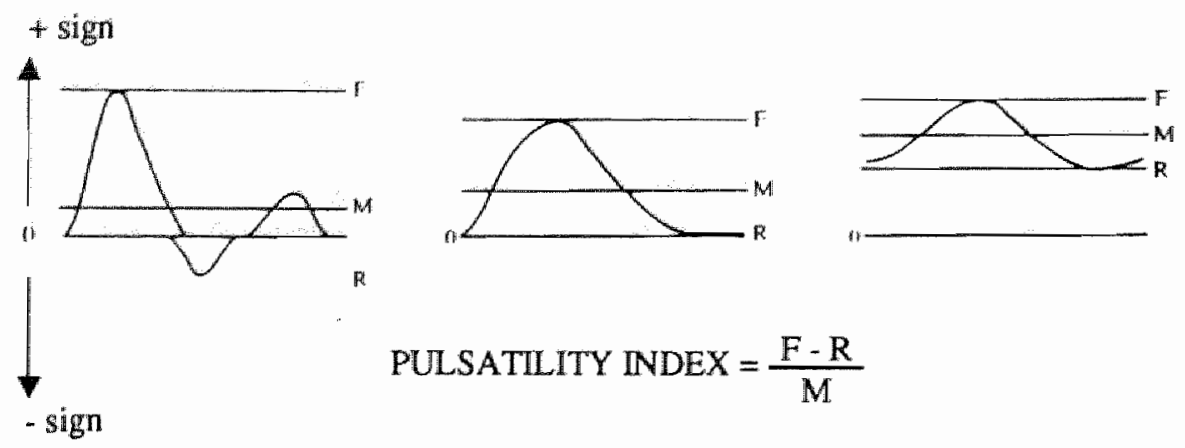

Fig. I-14: Definition of the Pulsatiliny Index. $F=$ maximum forward deflection of the curve. $M=$ mean level of the rurve over one cycle calculated by subtracting the area under the reverse curve, if any. from the tolat area under the forward curve(s) and dividing it by the duration of the cardiac cycle. $R=$ maximum reverse deflection. if any, with a negative sign (lefi figure), or lowest positive deflection in the absence of a reverse component (right and middle figure) (afier Kitslaar 1982 ).

The advantages of the PI are that it is independent of the angle of interrogation, carrier frequency, the velocity of sound in tissues transversed and the probe-vessel distance.

The disadvantages especially concern the aorto-iliac pathway. The PI is not only affected by inflow, but also by changes in peripheral resistance and heart rate. A low heart rate increases the diastolic length, which reduces the mean value, and thereby increases the PI. Tachycardia reduces the PI (Bird 1980, Clifford 1981). Besides, the PI is influenced by the arterial wall compliance.

All clinical studies described herewith were performed with recordings made in the femoral arteries.

The best results were obtained by the group of Johnston (1983). They found the PI to be $95 \%$ sensitive and specific in detecting hemodynamically significant aortoiliac diseases that comespond to a resting aortofemoral pressure difference of $10 \mathrm{~mm} \mathrm{Hg}$ or more in patients without a femoropopliteal occlusive disease. In the patient group, without knowing the state of the femoropopliteal pathway, the results declined to a sensitivity of $93 \%$, a specificity of $88 \%$. They believed the results to be better than those of others, because (1) the examination was performed after a period of rest, partly eliminating the effect of peripheral resistance on $\mathrm{PI}$; (2) the use of a $4 \mathrm{MHz}$ probe, 
restilting in a better signal/noise ratio, especially in the deep femoral arteries; (3) the use of a CW Doppler device which provides less variability than a pulsed Doppler systems.

Jorgenson (1985) used a pulsed wave Doppler ultrasound flowmeter in detecting aortoiliac stenosis. He observed a progressive reduction of the PI with increasing grades of stenosis.

The results, reported by other investigators, were less promising. In experimental studies on dogs Mc Pherson (1984) found that the PI was diagnostic only when the lumen area is reduced by more than $88 \%$. The effect of peripheral resistance on the PI is likely to be the major cause of this lack of sensitivity. This was already suggested by Evans and Barrie (1980), who performed about 200 pressure and PI measurements in a series of experiments on dogs distal to implanted arterial stenoses of varying length and cross-sectional area. In this animal model only a very tight stenosis (86\% area reduction) produced a PI low enough to be diagnostic of inadequate inflow. It could be argued that the PI is of less value in experimental than in human studies, but, in 11 young healthy adults Skidmore and Woodcock (1980) found a wide variance in PI.

Conceming the aortoiliac pathway the results obtained by others are even less encouraging. In 45 patients Demorais(1981) found that the PI values correlated ( $r=$ 0.82 ) with the pressure gradient, as directly measured across the aortofemoral segment, only in patients having an isolated aortoiliac disease. To diagnose aortoiliac stenoses Thiele (1983) compared the PI values with pressure measurements. When the measurements were performed at rest a sensitivity of $99 \%$, a specificity of $45 \%$, and an accuracy of $62 \%$ was found. With reactive hyperemia the figures were $92 \%, 51 \%$, and $69 \%$, respectively. These results refer to patients with combined diseases (81 patients).

For these reasons we did not use the PI in this study, especially because the method is less accurate in the case of multilevel diseases, a common situation in many patients.

\section{DAMPING FACTOR:}

The damping factor is defined as the ratio of the PI at a proximal site and the PI at a more distal site of the arterial tree.

The advantage of the damping factor is that it neutralizes the effect of lesions proximal as well as distal to the site of measurement. Skidmore ( 1980 ) found that one could distinguish between lesions with different grades of narrowing in the femoropopliteal segment with the use of this factor.

On the other hand the experimental work of Evans and Macpherson (1981), performing measurements on the iliac arteries of dogs, showed that the damping factor was only able to distinguish stenoses with an area reduction more than $85 \%$. Also Junger (1984) stated that the damping factor cannot separate the minor and moderate lesions (less 
than $50 \%$ diameter reduction in the actoiliac segment) from the severe lesions (more than $50 \%$ dimeter reduction or occlusion) in patients having multilevel diseases.

\section{TRANSIENT TMME:}

Craxford and Chamberlain (1977) defined Transient Time (TT) as the time interval between the peak of the R-wave of the ECG to a standard reference point (the midway point) on the upslope of the velocity waveform (using the analog signal). On the other hand, Auckland and Hurlow (1982) defined the TT as the time delay berween the proximal and distal sonograms, using two Doppler probes simultaneously (CW spectrum anallysis's).

Bruins Slot (1981) used the time-delay between the R-wave of the ECG and the arrival of the systolic velocity peak at proximal and distal site. In his study on the femoropopliteal pathway, using a pulsed Doppler system, the TT is determined by the pulse wave velocity and the length of the interposed arterial segment.

The advantage of TT-measurements (with measurements at two sites) is the independence of time-related changes such as cardiac arrhythmia's and respiration. They are also relatiwely independent of the state of the arterial pathway proximal of and distal to the site of measurement. The most important disadvantage is that these measurements are time-consuming.

Concerning the aortoliac segment, Ward (1980) found no significant difference between normal subjects, patients with less than $75 \%$ stenosis (lumen reduction), and those with more than $75 \%$ stenosis when using TT as parameter.

\section{LAPLACE TRANSFORM:}

The instantaneous blood flow velocity waveform, as recorded in an artery, e.g. the common femoral artery, can be digitized to calculate the Fourier transform. A third order mathematical model describes the waveform by the following equation:

L.aplace transform $=$

$$
\left(\mathrm{S} 2+2 \partial \mathrm{W}_{0}+\mathrm{W}_{02}\right)(\mathrm{S}+\mathrm{g})
$$

in which:

$\mathrm{g}$ is related to the degree of vasoconstriction, or vasodilatation of the peripheral vascular bed (or distal impedance);

Wo represents the elasticity or wall stiffness of the artery;

$\partial$ represents the degree of proximal stenosis, or the proximal arterial lumen size.

It has been postulated by Skidmore and Woodcock (1980) that the Laplace 
transform is sensitive for determining the presence of minor stenosis in the aortoiliac segment ( $\partial$ ), for determining changes in the elastic modulus of the proximal wessels (Wo), and for studying changes in distal impedance (g).

Baird (1980) found the Laplace transform to differentiate between liac stenoses with more or less than $50 \%$ diameter reduction, with a sensitivity of $85 \%$ and a specificity of $84 \%$. The Doppler velocity waveforms were obtained in the common femonal artery. Using this parameter Campbell (1983) found no differentiation with patients having combined aortoiliac and femoropopliteal diseases.

\section{RISE TIME RATIO:}

Humphries (1980) described the rise time (RT) as the time interval between the onset and the peak forward frequency of the waveform.

The rise time ratio is a probe-angle independent variable, relies on complete insonation of the artery and can be obtained manually from the waveform.

Recently Kitslaar (1988) used the parameter (called UST or upslope time) in a comparison with maximum forward frequency, maximum reverse frequency and pulsatility index derived from Doppler signals obtained in the femoral artery. The non-invasive parameters were related to femoral artery pressure measurements (FAP) and single plane arteriography. His conclusion was that overall conrelation of these parameters with apriori classifications of the aortoiliac segments, based on the FAP measurements and angiography, were poor. Of the described Doppler waveform parameters the UST appeared the parameter with the best predictive value for significant aortoiliac stenosis.

\section{HEIGHT WIDTH INDEX (HWI):}

HWI $=$ PI $\times$ duration of cardiac cycle / duration of the systolic peak

The definition of this index is based on the observation that waveforms recorded distal to arterial stenosis have both smaller peak forward and smaller peak reverse flow frequencies relative to the mean value, while the duration of the systolic peak is greater than that of a normal waveform. HWI is essentially independent of the probe/vessel angle.

Johnston (1984) found a diagnostic accuracy of $91 \%$ with the HWI for detecting severe aortoiliac stenoses (more"than $50 \%$ diameter reduction or complete occlusion) screening the femoral artery, unaware of possible distal stenosis. No further information about this parameter could be found in the literature.

7. REACTIVE HYPEREMIA RECOVERY TIME (T1/2):

In the reactive hyperemia test upon cuff release, a hyperemic response occurs with an increase in mean flow velocity of the Doppler signal recorded at the femoral artery . 
This is followed by a recovery phase. The femoral mean Dopplet flow velocity was constandy medsured before, during and after the occlusion time. The occlusion was performed with a thigh cuff distal to the common femoral artery. TI/2 is the time taken to decrease from the maximum value of the mean Doppler velocity to a value halfway the maximum and the prerelease level. The mean T1/2 walue increases with increasing severity of atherosclerotic disease as diagnosed arteriographically and all the iliac grades differed significantly from those of the normal group.

In a group of $\$ 2$ patients Ward (1980) could differentiate between iliac stenoses with more or less than $75 \%$ lumen reduction, irrespective of the presence of additional diseases of the superficial femoral artery.

No further reports on this parameter could be found in the literature.

\section{POWER FREQUENCY SPECTRUM ANALYSIS:}

Harward (1987) used power frequency spectrum analysis (PFSA) on CW Doppler signals as recorded in the common femoral artery of 86 limbs before and after a postocclusive reactive hyperemia test. In PFSA the power (amplitude) of the recorded signal is plotted as a function of frequency. In this Power frequency spectogram the vertical axis represents amplitude and the horizontal axis the frequency. This test was fatrly accurate in distinguishing proximal lesions with less than $50 \%$ diameter reduction from those with more than $50 \%$ diameter reduction, regardless of distal disease at $50 \%$ peak amplitude in the Power frequency spectogram.

III-6 Conclusion:

Table 1-3." Rerults of the different methods concerning aortoiliac lesions.

\begin{tabular}{|c|c|c|c|c|}
\hline mathos & author & Sensitjuity & specificity & mothad compared winh \\
\hline PII. & $\begin{array}{l}\text { Johnston } \\
1983\end{array}$ & $95 \%$ & $95 \%$ & $\begin{array}{l}\text { aortofemoral rest pressure } \\
+/-10 \mathrm{~mm} \mathrm{Hg}\end{array}$ \\
\hline \multirow[t]{2}{*}{ PI } & "Thicle & $99 \%$ & $45 \%$ & $\begin{array}{l}\text { aortofemonal rest pressure } \\
+/ 10 \mathrm{~mm} \mathrm{Hg}\end{array}$ \\
\hline & 1983 & $92 \%$ & $69 \%$ & $\begin{array}{l}\text { femoral pressure at reactive } \\
\text { hyperemia }+1-20 \mathrm{~mm} \mathrm{Hg}\end{array}$ \\
\hline LTT & Baird 1980 & $85 \%$ & $84 \%$ & $\begin{array}{l}+1-50 \% \text { diami red. on } \\
\text { arteriogram }\end{array}$ \\
\hline $\mathrm{PH} S \mathrm{~A}$ & Harwatrd 1987 & $93 \%$ & $92 \%$ & $\begin{array}{l}+1-50 \% \text { diam red. on } \\
\text { arteriogram }\end{array}$ \\
\hline
\end{tabular}

The results of the different methods useful in detecting aortoiliac stenoses are summarized in table I-3. Johnston and Thiele compared the Pulsatility Index with intra arterial pressure measurements. Although the sensitivity of the PI is excellent, Thiele 
found a low specificity in his examinations. Baird and Harward compared the PI with diameter reduction on the arteriogram. Furthermore no agreement can be found in the literature about the exact interpretation of the PI results for the sortoliliac pathway. Power frequency spectrum analysis seems more sensitive and specific than the Laplace transform.

Although relatively good results were obtained, interpretation of the signals by means of Laplace damping and Power frequency spectrum analysis is in our opinion too complex to perform as a routine clinical procedure.

After our examinations had been performed, Walton (1984) published an approach similar to the one described in the present study ( see discussion).

\section{BIPLANE ARTERIOGRAPHY AND PRESSURE MEASUREMENTS IN AORTOILIAC ARTERIES.}

\section{IV-1 Biplane arteriography:}

Arteriography has been used as a gold standard for the evaluation of arterial diseases for many years. With the increasing accuracy of non-invasive techniques and the use of pressure measurements, it is doubtful whether arteriography is still the gold standard. Even when biplane views are available (Brener 1974, Brewster 1979, Castaneda-Zuniga 1976, Faris 1982, Flanigan 1977, 1981,1982, Moore 1971, Quinn 1975 ) arteriography has certain limitations. It only provides a two-dimensional approximation of the arterial lumen, whereas it does not give any information about conditions other than circumferential stenoses that impair hemodynamics. Changes in the visco-elastic properties of the vessel wall as well as irregular surfaces, producing flow disturbances locally, may not be detected. These factors can be of little importance during the relatively slow, resting flow rates. With increasing flow, as during exercise, however, they can take a considerable significance (Moore 1971).

Besides, arteriography is not free of morbidity, and such adverse effects as arterial lesions, nefrotoxity (Lang 1980) and allergic reactions (Shehadi 1980, 1982) have been reported.

Nevertheless biplane views give more information than single plane views (Sethi 1975). Oblique projections of the common iliac artery bifurcations, and in our experience the common femoral bifurcation, are of great value in evaluating arteriograms. An obliquity of about $30 \%$ gives the best overall view of the origin of the arteries (Thomas 1972). 


\section{NV-2 Pressure measurements:}

Pressure is related to flow only when there is such a degree of stenosis that there is no autoregulation anymore (see fig 1-3). In moderate to severe stenosis pressure meaturements could give valuable information about the degree of stenosis (Keitzer 1965). In recent literature pressure measurements are believed to be a new "gold standard". Indeed, if there is a pressure drop along the antery "then an important stenosis must exust. Brewster (1979) found a disagreement between the angiographic interpretation and physiological evaluation, based upon his pressure measurement tests, in one quarter of his patients.

In our opinion it is important to find out how the pressure differences are expressed, absolutely or relatively. Patients have different blood pressures and even the same patient can show important differences especially when examinations are performed. Some investigations express the pressure measurements in $\mathrm{mm} \mathrm{Hg}$. others in relative \%. If different patients are compared to each other, it is necessary to express the pressure differences as a percentage, as a relative measure.

When using the Seldinger technique for performing arteriography, the same catheter can be used for pressure measurements. This has been described by various authors (Brener 1974, Brewster 1979, Lorentson 1972) and we have used this approach in the present study.

According to the results of the non - invasiwe tests it is possible to choose the site of puncture for arteriography in order to perform simultaneous pressure measurements at the desired sife. The only possible complication, namely arterial damage, is then included" while performing the test together with arteriography.

\section{Pressure measurements at rest}

In the aortoiliac pathway the catheter, as placed in the aorta, can be withdrawn to the common femoral artery. It is also possible to measure the pressure at different sites in the aortoiliac tree. In nomal healthy arteries the pressure as measured along this tree, barely changes. The reason why was already discussed in chapter II-1. In diseased anteries it may be possible to detect a pressure drop. In moderate to severe lesions this pressure drop is partly related to the degree of stenosis, as demonstrated by the experimental work of Keitzer (1965).

\section{Pressure measurements during reactive hyperemia}

A second important parameter is the pressure measurement during a period of increased flow. Symptoms of claudication occur in a hyperemic phase (walking). Therefore, it is important to measure the pressure during exercise to evaluate the hemodynamic state. In exercise the flow increases. Stenoses, which do not produce a 
pressure drop at rest, may induce a clear pressure drop during exercise (Alamigan 1984).

There are two common methods in use to produce a flow increase. One makes use of a cuff around the thigh and in this method the femoral artery is occluded during a short period of time. Following release of the cuff a reactive hyperemia response will be elicited and flow increases. We have used this method in our study, as will be discussed llater.

The other method is to inject papaverine intra-arterially. Papaverine is a vasodilatator and, hence, increases blood flow.

\section{TV-3 Discussion:}

In table I-4 the results of pressure tests performed by various authors are summarized:

Table 1-4: The different pressure measurements with their results

\begin{tabular}{|c|c|c|c|c|}
\hline vear & author & nir pat* & method used & cul off point \\
\hline 1971 & Moore & 40 & calf exercise & $\begin{array}{l}>9 \mathrm{~mm} \mathrm{Hg} \text { difference } \\
\text { between two opposite } \\
\text { femoral } \mathrm{Aa}\end{array}$ \\
\hline 1972 & Lorentson & 25 & cuff & $\begin{array}{l}20 \mathrm{~mm} \mathrm{Hg} \text { gradient } \\
\text { (brachial /femoral aa) at rest } \\
\text { or reactive hyperemia } \\
10-20 \mathrm{~mm} \text { Hg: important } \\
\text { lesion }\end{array}$ \\
\hline 1975 & Quin & 54 & papaverine & $\begin{array}{l}18 \% \text { pressure drop at } \\
\text { reactive hyperemia }\end{array}$ \\
\hline 1979 & Brewster & 150 & cuff & $\begin{array}{l}5 \mathrm{~mm} \mathrm{Hg} \text { at rest and/or } 15 \% \\
\text { pressure decrease at reactive } \\
\text { hyperemia }\end{array}$ \\
\hline 1979 & Udoft & 42 & papaverine & $\begin{array}{l}20 \mathrm{~mm} \mathrm{Hg} \text { decrease at } \\
\text { reactive hyperemia }\end{array}$ \\
\hline 1981 & Archie & 44 & papaverine & $\begin{array}{l}10 \mathrm{~mm} \mathrm{Hg} \text { decrease at } \\
\text { double resting blood flow }\end{array}$ \\
\hline 1983 & Flanigan & 43 & papaverine & $\begin{array}{l}15 \% \text { decrease of fem/brach } \\
\text { index at reactive hyperemia }\end{array}$ \\
\hline 1985 & Verhagen & 45 & cuff & $\mathrm{GA}^{*}>70 \%$ or $\mathrm{IG}^{*}>20 \%$ \\
\hline
\end{tabular}

"nr. pat. : number of patients in each study

* $\mathrm{GA}=$ femorobrachial systolic blood pressure index at rest

* $I G=$ difference between $\mathrm{GA}$ index at rest and $\mathrm{GA}$ index after $15 \mathrm{sec}$ reactive hyperemia.

One of the furst to describe intra-arterial pressure measurements were $\mathbb{W}$. Moore and A. Hall in 1971. In their study 40 patients with intermittent claudication, whose arteriograms failed to indicate iliac stenoses, were studied. Twenty-eight patients were found to have iliac artery diseases by exercise test (calf exercise). Seventeen of these 28 underwent aortoiliac reconstruction with a succes of $95 \%$. They performed simultaneous 


$$
-36-
$$




\section{PART II OWN EXAMHATIONS}

\section{V.PATIENTS:}

The study was performed on 100 patients. All patients were hospitalized and came for the first time to the General Surgical Clinic (Catharina Hospital - Eindhoven). None of them underwent reconstructive peripheral vascular surgery before. All patients were examined by the author prior to arteriography and at that time he was unaware of the clinical state of the patients or the vascular complaints. The patient group consisted of 79 men and 21 women, with a mean age of 60.7 years. The age distribution is shown in fig. II-1

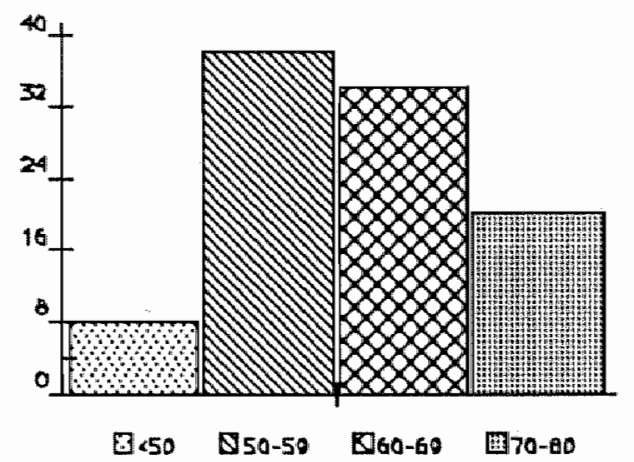

Fig. I1-1: Age distribution in the patien group

Eleven of these patients suffered from hypertension. One patient had cardiac valve disease. Three patients had thythm disturbances. Thirty-four patients showed angina pectoris by history. Sixteen patients had previous cerebrovascular disorders. Six of our patients had both angina pectoris and cerebrovascular diseases. Five patients suffered from diabetes (table II-1). Red blood cell count was above normal in two patients and lower than normal in 15 patients. (normal : $4.0-5.4 \mathrm{milj} . / \mathrm{mm} \mathrm{3}$ ) 
Table H.1: differen clinical pathotogy in the described patien group

$\begin{array}{lr}\text { hypertension } & 11 \\ \text { walve lesion } & 1 \\ \text { rythm disturbances } & 3 \\ \text { angina pectoris } & 34 \\ \text { cetebrovascular disorders } & 16 \\ \text { diabetes } & 5\end{array}$

If we do consider a patient having a combined disease when the aortoiliac stenosis is $\geq 40 \%$, and the outflow stenosis $\geq 30 \%$, then 30 out of 200 legs or $15 \%$ of the examined legs have this combined disease. If we reduce those figures to $30 \%$ aortoiliac stenosis and $20 \%$ outflow stenosis, then $48 \mathrm{legs}(24 \%)$ have a combined disease.

\section{METTIODS OF EXAMINATION:}

\section{VI-1. Examination of the patient:}

All patients were transported to the examination room in a wheel-chair. The patients were placed in the supine position and were rested for approximately 10 minutes. The Doppler examinations were performed on both sides, starting alternately from the femoral or from the illiac artery. Localization of the intra-abdominal arteries requires experience, especially in the beginning. If the examiner is uncertain of the artery's localization, the external iliac wein signal may be used as an identifying landmark (Strandness 1967). Flow direction, for instance, is another good landmark. For instance, in cases with a $100 \%$ stenosis of the extemall iliac artery, we were able to localize the reversed signal of the internal ilac artery, provided that this artery was not occluded.

All measurements were performed after screening each artery.

The cuff pressure was taken on both arms. No significant differences beiween both sides were found in our patient-group. The pulsations of femoral, popliteal, and tibial arteries were palpated, and graded as 0 : absent, * : weak, +t : good, normal pulsation. The abdomen and groins were screened for bruits. If there were bruits, then a gradation was made between + : soft murmur and ++ : loud, clear murmur.

\section{V1-2 Classification of Doppler spectra:}

Based upon an open study of 25 patients (Haeck 1983), in which the changes in the 
Doppler parameters were compared with the findings at arteriography, we came to six Doppler patterns to describe the severeness of the disease. These are summarized in tabie II-2.

Pattem I: the normal audiospectrum consisting of three waves: (1) a systolic wave with a clear systolic peak and an upslope of $\leq 3$ degrees, (2) a clear reversed wave, (3) a second forward wave and an averaged calculated window $\%$ of more than $65 \%$ (see fig. II-2). Pattem II is characterized by (1) a systolic wave with a clear systolic peak and an upslope of $\leq 3$ degrees, (2) a diminished or absent reversed wave, (3) no second forwand wawe and (4) a window \%o of more than $65 \%$ (see fig. [i-3).

Pattern III is characterized by (1) a significantly prolonged upslope in the systolic wave, the upslope is $>3$ degrees, (2) the absence of a clear systolic peak, which is attenuated or flattened, (3) a normal, diminished, or absent reversed wave, (4) and a window of of more than $65 \%$ (see fig. II-4),

Pattem IV is characterized by (1) an increase in maximum frequency of more than $6 \mathrm{kHz}$ during systole, (2) a diminished upslope, (3) the absense of a peak and the absence of a reversed wave and (4) a window $\%$ of less than $65 \%$ which reflects spectral broadening. Sometimes there are negative frequencies, probably representing reflections (see fig. II $-5)$.

Pattern $\mathrm{V}$ is characterized by (1) a damped tracing with low maximum frequencies, (2) no clear peak is visible (3) the absence of a reversed wave and (4) a complete filling in of the window (see fig. II-6).

Pattern VI: no signal can be detected.

Table 1-2: classification of the different Doppler spectra

\begin{tabular}{|c|c|c|c|c|c|}
\hline & systolic peak & upslone & reversed wave & second forward wave & windiow os \\
\hline I & clear & $\leq 3^{\circ}$ & clear & clear & $>65 \%$ \\
\hline II & clear & $\leq 3^{\circ}$ & $\begin{array}{l}\text { diminished } \\
\text { or absent }\end{array}$ & absent & $>65 \%$ \\
\hline m & aticnuated & $>3^{\circ}$ & normal & $\begin{array}{l}\text { absent } \\
\text { diminished }\end{array}$ & $>65 \%$ \\
\hline $\begin{array}{l}\mathrm{IV} \\
\mathrm{V}\end{array}$ & $\begin{array}{l}\text { no clear peak } \\
\text { dampod }\end{array}$ & $\begin{array}{l}\leq 3^{\circ} \\
\text { dampod }\end{array}$ & $\begin{array}{r}\text { or absent } \\
\text { absent } \\
\text { absent }\end{array}$ & $\begin{array}{l}\text { absent } \\
\text { absent }\end{array}$ & $\begin{array}{r}<65 \% \\
\text { filling in }\end{array}$ \\
\hline
\end{tabular}

The hereby described method is very different from those described in part $\mathbb{I}$. Indeed, we use a combination of different parameters which by themselves can be indicative for lesions and are used in the earlier mentioned studies namely: the maximum 
systolic peak, the upslope, the reversed wave and the window $\%$. A combination of the differen parameters results in the definition of a Doppler class. This class becomes a patuern which can be wisually interpreted.

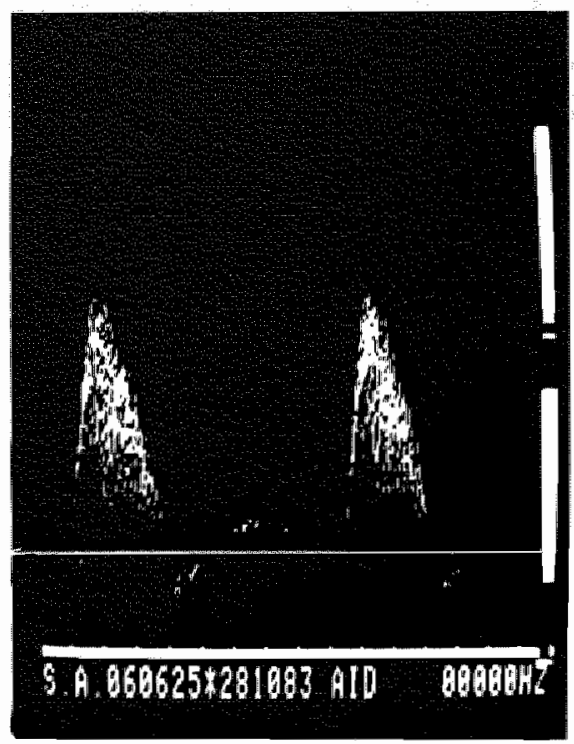

Fig. It - 2: Audiospestrum of ilias artery - CLASSI

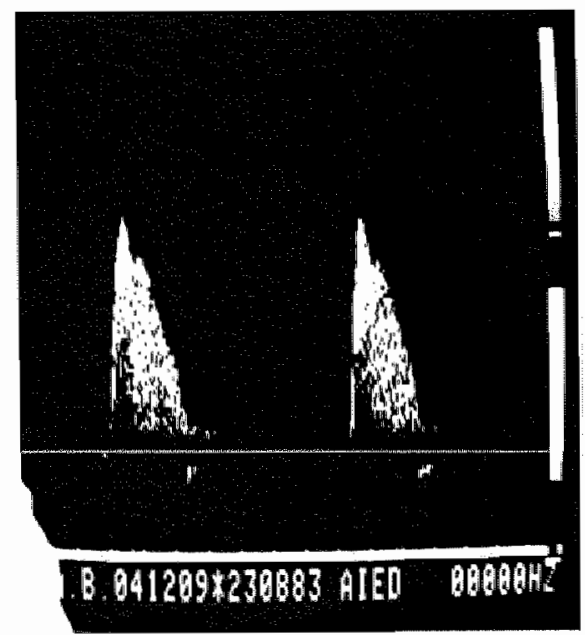

Fig. II - 3: Audiospectrum of iliac artery - CLASS II 


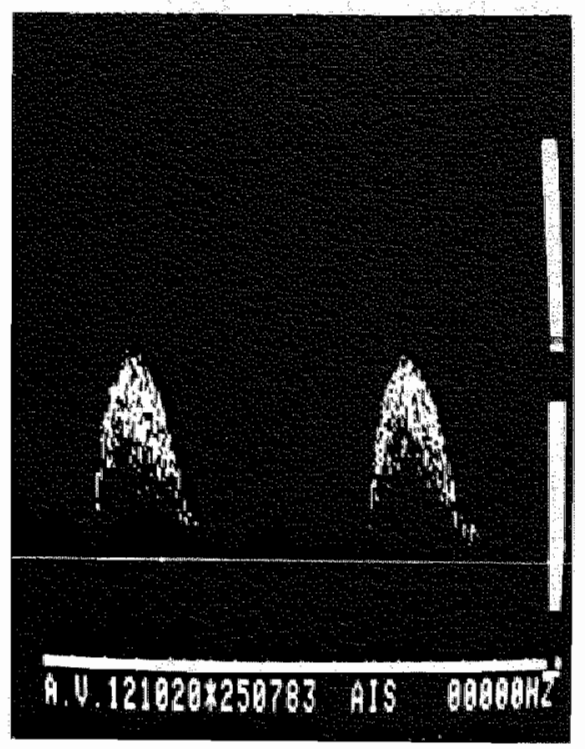

Fig, II - 4: Audiospectrum of iliac antery - CLASS III

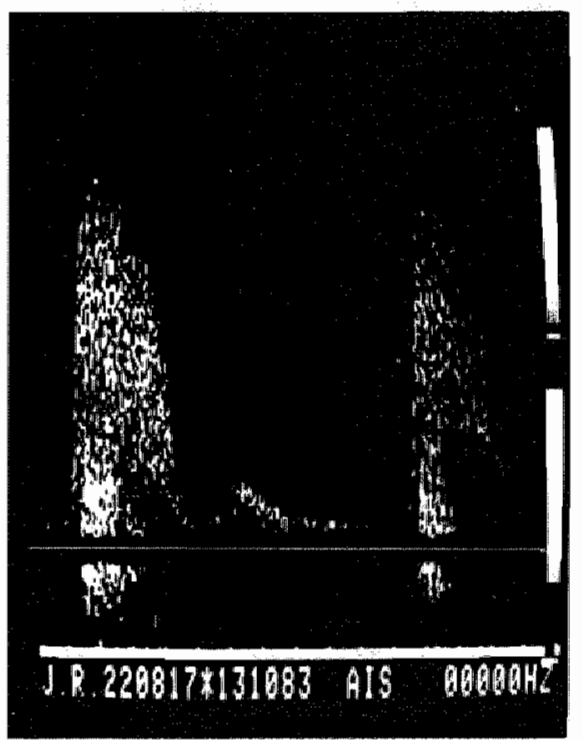

Fig. II - 5: Audiospectrum of iliac antery - CLASS IV 


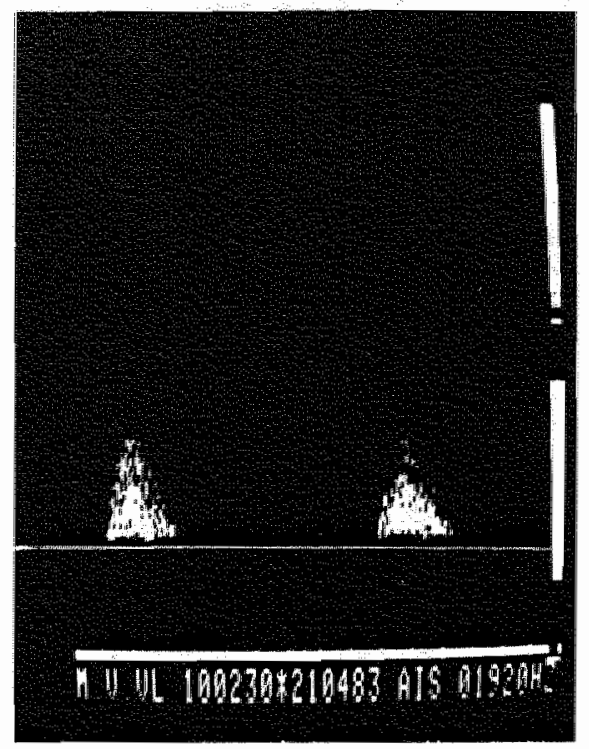

Fig. II - 6. Audiospectrum of iliac artery - CLASS V

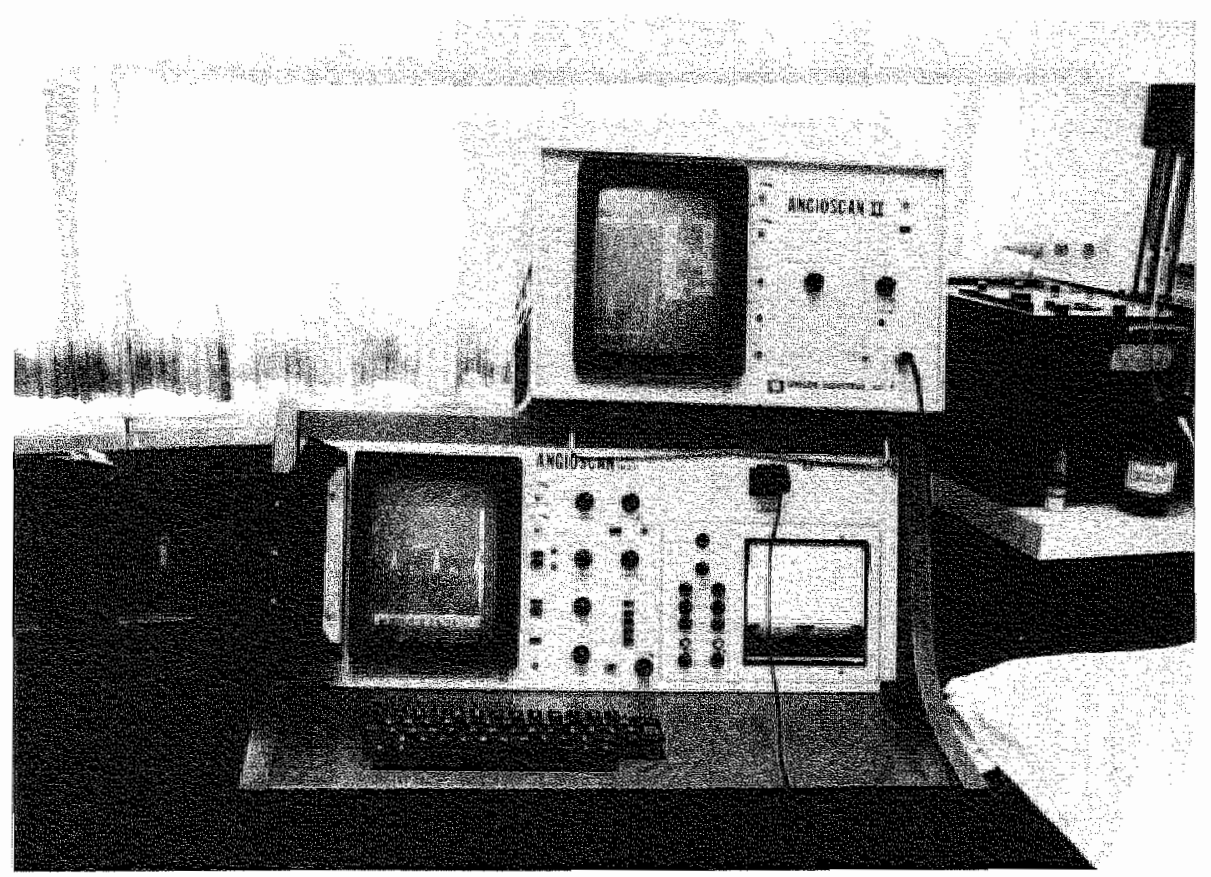

Fig. $/ 1$ - 7: The Angioscan $I /$ - Unigon Industries Inc. 
VII - 1 CW Doppler with audio-spectrum frequency analyser.

All Doppler tests were performed with the Angioscan II (\$), produced by Unigon Industries Inc. The instrument exists of a CW Doppler device and a spectrum analyser with two video displays and a built-in microcomputer. The equipment is shown in figure II-7. The spectrum is displayed in the "sonogram" format with frequency as abcissa, the time axis extending from left to right in a continuous rolling display, and spectral power as trace brightness. The image can be freezed. Excessive wall movement artifact may be removed by a switchable high pass filter, generally used at a lower cut-off frequency of $300 \mathrm{~Hz}$. The analysis was performed by means of a digital Fast Fourier Transform producing a 128 frequency point spectrum on the frequency axis. The frequency ranges are 5,10 , and $20 \mathrm{kHz}$. The analysis time is $6.5 \mathrm{msec}$. and as 256 spectra are displayed, the time axis extends for 1.6 seconds. A cursor is available over the full screen. On the other screen the averaged values of peak systolic wave, mean forward frequency and window percentage are available. In our study the averaged parameters were computed based upon fifteen consecutive beats. The Angioscan II (B) was triggered with an internal signal which was the intersection of the built-in cursor with the peak frequency.

For screening the iliac and femoral arteries a $4 \mathrm{MHz}$ probe was used. As mentioned before, screening arteries lying at a greater distance from the Doppler probe, the emitted signal must have a lower frequency than is necessary for screening more superficial arteries.

After completing the examination of an artery, the following parameters were assessed: (fig $[-12$ ):

1. S peak averaged: The peak frequency of the sonographic waveform averaged over 15 sonograms.

2. S mean averaged: The arithmetical average of the mean forward frequency of the first wave, as derived from each sonographic waveform, and averaged over 15 sonograms.

3. Second forward wave: As measured by placing the cursor on this part of the sonogram with the maximum intensity (single).

$4 . R$ : the reversed wave with the maximum intensity was chosen. Then the peak of the reversed wave was measured by placing the cursor on this part of the sonogram.

5. S\% window averaged: The $\%$ window was defined as the average area below the lower bandwidth divided by the average area below the upper bandwidth. The upper bandwidth was defined as the $12 \mathrm{db}$ point below the mode amplitude, the lower bandwidth as the $-12 \mathrm{db}$ point below the mode amplitude. The mode is the frequency of 
maximum amplitude in the spectrum. The number for the percent window is dimensionless. The S\% window was averaged over 15 sonograms.

6. Upslope: This was defined as the time delay between the onset of the systolic waveform and the peak of this waveform. (handmeasured in msec)

7. Angle of upslope: The angle between the vertical cursor (frequency-axis) and the line berween onset and peak of the systolic waveform (handmeasured in degrees).

8. Class: Each sonogram was giwen a Doppler Class (femoral, or illac) as shown in chapter $11-2$

\section{VII-2 Arteriography and Pressure measurements:}

V11-2-1. Methods:

The arteriographies were made by different radiologists, using the Seldinger technique. The site of puncture was usually transfemoral, and chosen on the basis of the results of the non-invasive tests performed by myself the day before. If the examinatior presumed an aortoiliac lesion, the radiologist was asked to perform the arteriography on that side. In some cases transfemoral puncture could not be performed and then the transaxillary route was chosen. The Röntgen-apparatus used was the Polydiagnost UPI (®) with appertaining table the Angio Diagnost U2 (B) (Landmarn 1978). After performing the antero-posterior projection, the radiologist decided to take a left anterior oblique or right anterior oblique projection.

Finally, the Seldinger catheter was connected to a pressure transducer. Pressure tracings were recorded on a Philips(8) portable physiological recorder. Simultaneously, arm blood pressure was measured with an appropriate arm cuff using the Riva-Rocci method. These measurements were made several times during the examination and the average of these measurements was taken as the patient's reading. After registration of aortic pressure, the catheter was withdrawn into the common femoral artery and the pressure on this side was measured instantaneously. Then a wide $(25 \mathrm{~cm}) \mathrm{cuff}$ around the leg was inflated to $50 \mathrm{mmHg}$ above systolic arm pressure for five minutes and suddenly released. Pressure registrations in the common femoral artery began one minute before release of the cuff and were continued after release until the prerelease level was obtained. During this procedure arm blood pressure was measured three times. All registrations were performed by the same team of three technicians. It should be noted that in all patients arm blood pressure showed very little or no changes during the reactive hyperemia test ( $\max 4 \%$ ), which is in agreement with the findings of Sako (1966) and Brewster (1979). 
VII-2-2 Interpretation of the results:

All arteriograms. were examined at the end of the study by the author. At that time was unaware of the previously performed Doppler tests and the clinical state. For the aorto-iliac pathway the stenosis with the greatest narrowing was expressed as percentage diameter reduction, as compared to the normal lumen proximal of the stenosis. This was done at the two arteriograms available. Then the mean value of both percentages was taken as inflow stenosis $(0-100 \%)$. For the description of the outflow we used the method described by Kitslaar (1982). Stenosis of the common femoral artery was expressed relative to the proximal site as percentage of diameter reduction. In case of an isolated occlusion the outflow stenosis can be defined as follows:

- for the origin of the profunda femoris artery $\quad 50 \%$

- for the femoral artery $\quad 50 \%$

- for the popliteal artery $33 \%$

- for each of the lower leg arteries at their origin $\quad 8 \%$

In case of an isolated stenosis this was given a fraction of the corresponding occlusion score according to the following systern :

- stenosis $<50 \%=0 \%$ of the occlusion

- stenosis $\quad 51 \%-75 \%=40 \%$ of the occlusion

- stenosis $\quad 76 \%-95 \%=80 \%$ of the occlusion

- stenosis $>95 \% \quad=$ occlusion

This resulted in outflow stenoses varying between 0 and $100 \%$.

The pressure measurements are relative values and were performed as follows: - pressure test at rest : the systolic pressure in the aorta was recorded after performing arteriography during a period of rest. The systolic pressure in the common femoral artery was measured $30 \mathrm{sec}$ after withdrawal of the catheter from the aorta. A value averaged over 5 beats was taken as the correct figure. The pressure difference was assessed as a percentage of aortic pressure.

- pressure test during reactive hyperemia. After cuff-release systolic pressure was measured and averaged over five consecutive heart beats at the lowest pressure level recorded. The difference between this pressure and the pressure before cuff release was expressed as percentage pressure drop.

In Figure П- 8 a a pressure test during reactive hyperemia with little pressure decrease is presented. In fig II- $8 \mathrm{~b}$ a sudden decrease is shown after cuff-release. 


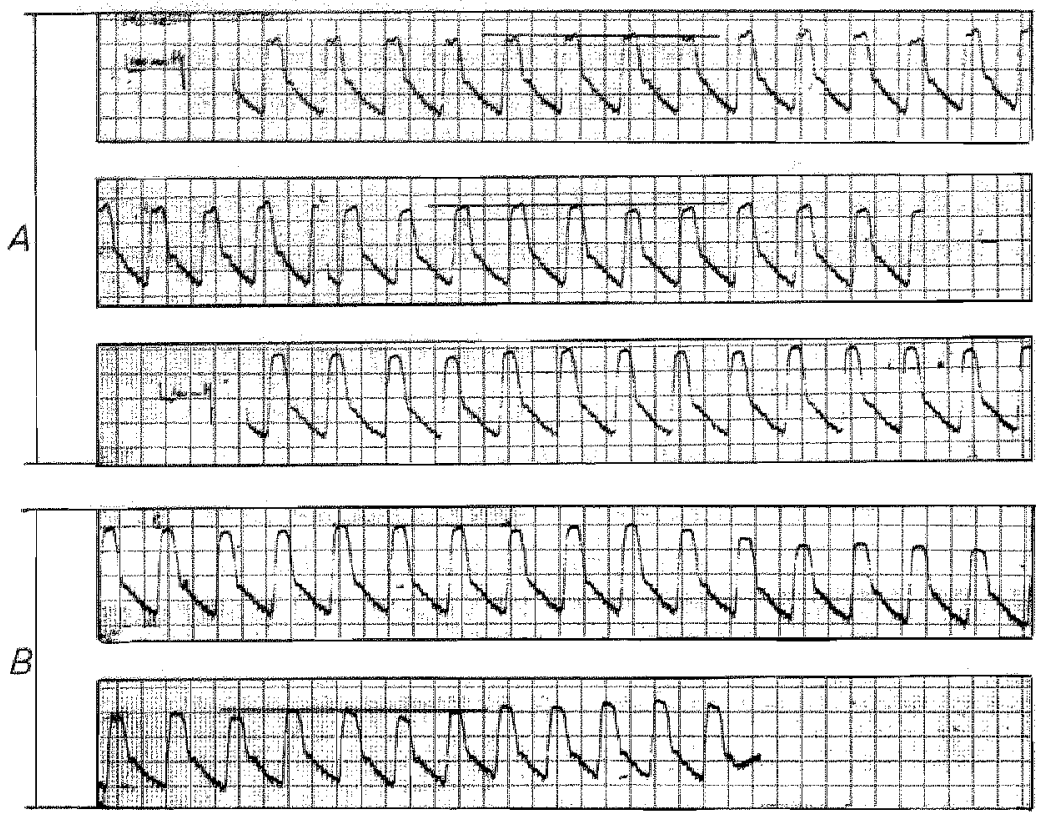

Fig. If - 8a.: Pressare test at rest (A) and during reactive hyperemia $(B)$ in the same patient with minar decrease.
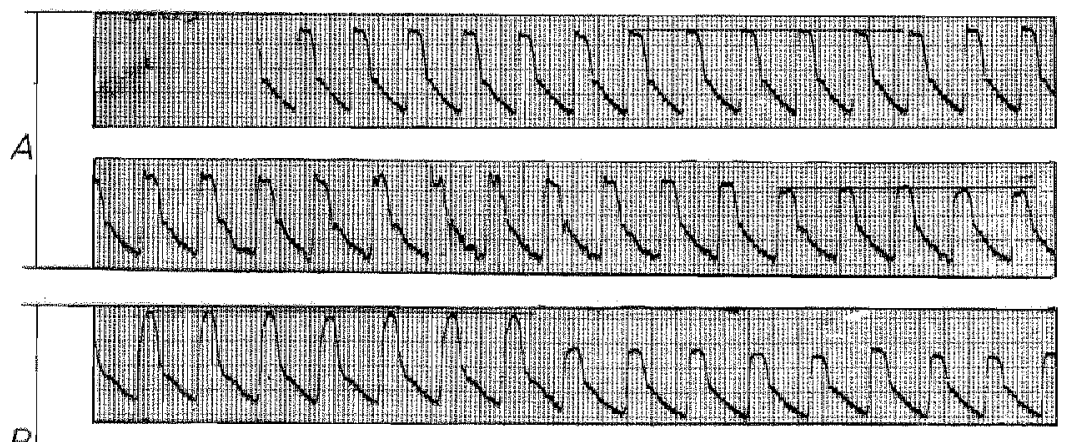

$B$

Fig. 11 . 86 . Pressure test at rest (A) and during reactive hyperemia ( $B$ ) in the same patient with sudden decrease afler cuff-release. 


\section{VIIL DATA PROCESSING:}

\section{Sensitivity/specificity decision matrix}

When comparing the results of Doppler tests on the one hand with arteriography and pressure measurements on the other, one can use the sersitivity/specificity decision matrix. The sensitivity is the ability of the test to detect patients with disease the specificity is the ability to exclude patients withou disease. We have postulated that pattem III to VI indicates a diseased artery and, hence, the Doppler test is considered to be positive when one of these patterns is found. The decision matrix is presented in table II3:

Table $1-3$ : Decision manix

\begin{tabular}{|lcll|}
\hline & disease $(t)$ & disease $(-)$ & total \\
Test $(+)$ & $\mathrm{A}$ & $\mathrm{C}$ & $\mathrm{A}+\mathrm{C}$ \\
Test $(-)$ & $\mathrm{B}$ & $\mathrm{D}$ & $\mathrm{B}+\mathrm{D}$ \\
Total & $\mathrm{A}+\mathrm{B}$ & $\mathrm{C}+\mathrm{D}$ & $\mathrm{A}+\mathrm{B}+\mathrm{C}+\mathrm{D}$ \\
\hline
\end{tabular}

Sensitivity: $\quad$ true + , diseased arteries traced by the Doppler test:

$$
\mathrm{A} /(\mathrm{A}+\mathrm{B}) \times 100 \%
$$

Specificity: true -, normal arteries traced by the Doppler test

$\mathrm{D} /(\mathrm{C}+\mathrm{D}) \times 100 \%$

positive predictive value:

negative predictive value:

diagnostic accuracy:

$$
\begin{aligned}
& A /(A+C) \times 100 \% \\
& D /(B+D) \times 100 \% \\
& (A+D) /(A+B+C+D) \times 100 \%
\end{aligned}
$$

\section{The receiver-operating-characteristic curve}

The receiver-operating-characteristic (R.O.C.) curve is a result of plotting the sensitivity and specificity against each other. This results in a concave curve, which facilitates the interpretation of the various results. In this method a range of arbitrarily chosen thresholds is used. That threshold value which results in a specificity and a sensitivity both nearest to $100 \%$ is considered to be the optimal one (Mc Neil 1975).

\section{The Mann - Whitney test:}

The Pearson chi-square coefficient associated with the Mann - Whitney test was used to evaluate differences between groups for statistical significance: a probability or p-value of $<0.05$ was considered to be significant. 


\section{RESULTS:}

X-1 The results when the Doppler audiospectra are recorded in the femoral arteries.

One of the aims of this study was to examine whether Doppler signals, as recorded in the liac arteries, yield more information about the severeness of the disease than those recorded in the femoral arteries.

In table II - 4 the results of the femoral recordings are compared with arteriography. The number of recordings indicative of stenosis is increasing with the increasing degree of harrowing, as found in the arteriogram. A division is made in different groups so that stenoses with a $\%$ diameter reduction of $40 \%, 50 \%$, and $70 \%$ can be distinguished.

Table II-4: Doppter audiospectrum class, when the signal is recorded in the femoral arteries, as compared wish the soliameter reduction, as found on the arteriogram.

\begin{tabular}{|c|c|c|c|c|c|c|c|c|}
\hline \multirow[b]{3}{*}{ femoral } & \multirow[b]{3}{*}{ I } & \multicolumn{6}{|c|}{ \%ortoiliac stenosis } & \multirow[b]{2}{*}{$\mathbb{N}$} \\
\hline & & $0.9 \%$ & $10-39 \%$ & $40-49 \%$ & $50-69 \%$ & $70-99 \%$ & $100 \%$ & \\
\hline & & 14 & 13 & 1 & 4 & 1 & 0 & 33 \\
\hline & II & 48 & 32 & 11 & 8 & 5 & 0 & 104 \\
\hline audio & III & 5 & 3 & 4 & 5 & 18 & 0 & 35 \\
\hline spectrum & IV & 4 & 1 & 3 & $\downarrow$ & 3 & 1 & 13 \\
\hline & $v$ & 0 & 1 & 0 & 0 & 5 & 8 & 14 \\
\hline class & $\mathrm{VI}$ & 0 & 0 & 0 & 0 & 0 & 1 & 1 \\
\hline & & 71 & 50 & 19 & 18 & 32 & 10 & 2000 \\
\hline
\end{tabular}

In figure lit-9 the number of recordings is plotted wersus different grades of stenosis, as found at arteriography. With a stenosis of $70 \%$ or more on the arteriogram the Doppler audiospectra are indicative of stenosis. 


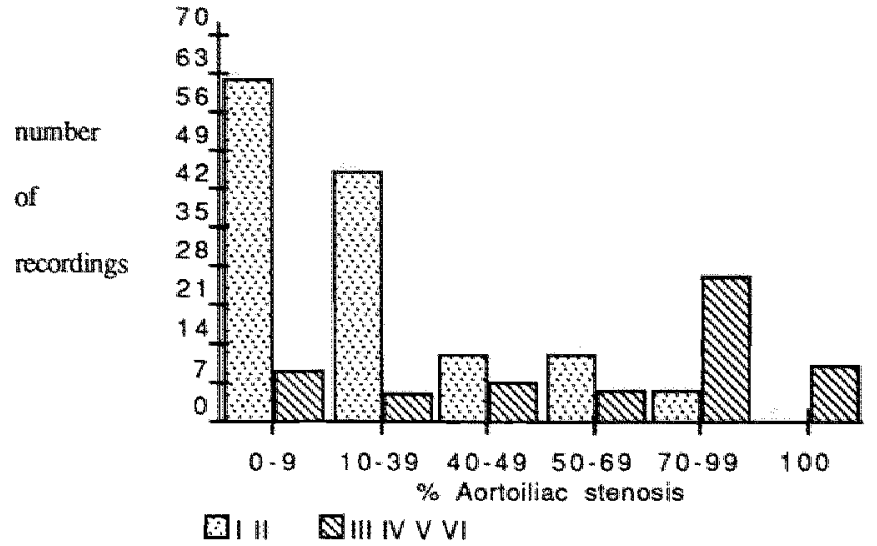

Fig. II -9: Number of femoral recordings in the various Dopplet classes plonted against different grades of stenosis on the arteriogram.

In figure II-10 the mean values of $\%$ diameter reduction of the aortoiliac stenosis, as assessed on the arteriogram, is plotted against the classification of the femoral Doppler recordings. Femoral Doppler class III, IV and V is mainly seen in illac arteries with a stenosis of $>40 \%$.

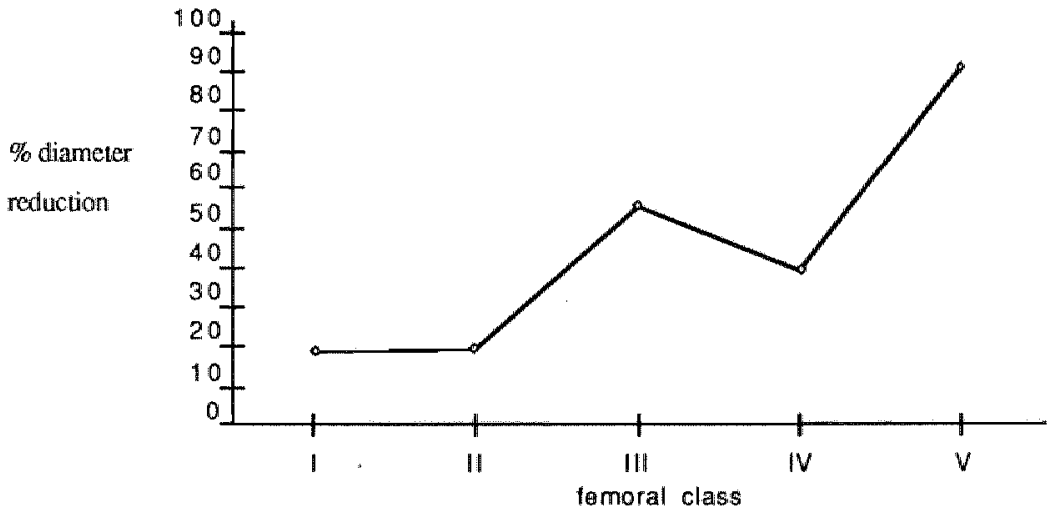

Fig. W-10: The mean witameter reduction, as assessed on the arteriogram, it the differen femoral Doppler audiospecrum classes. 
The resuls of the femoral Doppler examinations and of arteriography can be expressed in R. O.C. curwe. The resull is shown in fig. II. 11. The optimal sensitivity/specificity value is found with an aoroiliac stenosis of $69 \%$.

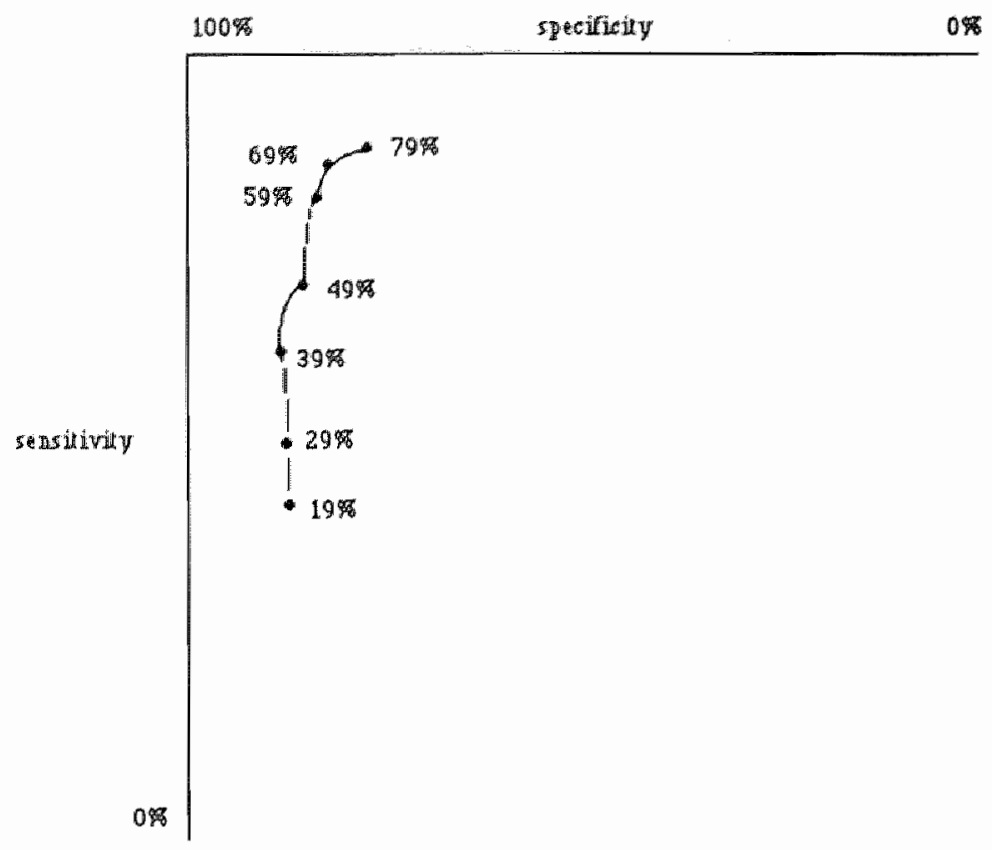

Fig. H-H: R.O.C. curve resuls of femoral Doppler examinations and \% aorloultac stenasix on the arieriogranl

The differentiation between more or less than $50 \%$ diameter reduction gives a sensilivity of only $70 \%$, a specificity of $85 \%$, a positive predictive value of $67 \%$, a negative predictive value of $87 \%$, and a diagnostic accuracy of $80 \%$. The method presented in this study, when recording the signals in the femoral arteries, is not sensitive anough to be used as a screening test for aortoiliac stenosis.

The results obtained with Doppler audio spectral analysis of the femoral artery signals, as compared to the pressure measurements at rest and during reactive hyperemia, are shown in figure II-12 and figure II-13, respectively. For class IV and $V$ the numbers obtained are too smail to draw any conclusions. In these figures the mean walue and 
standard deviation of the \% pressure drop in each class is presented.

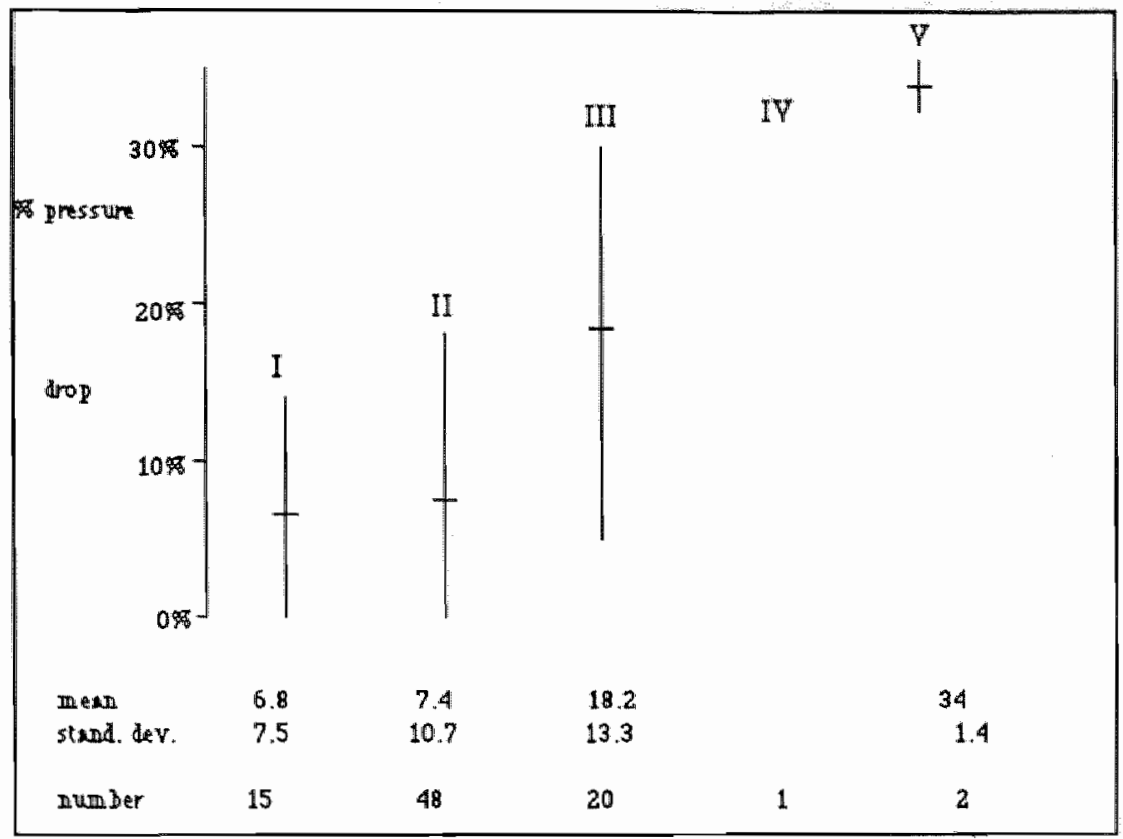

Fig. I1-12: Mean values and sundard deviation of o pressure drop in each fentoral Doppler audiospectrum class at rest.

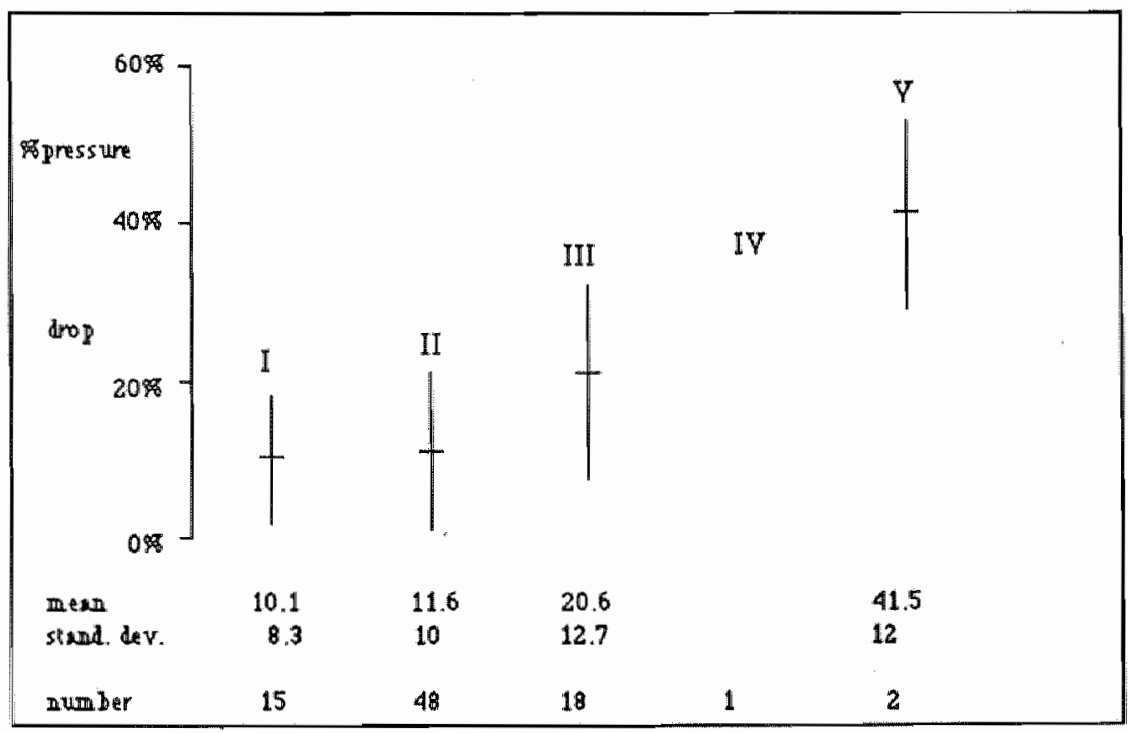

Fig. I1-13: Mean walues and standard deviations of of pressure drop in each femoral Doppler audiospectrum class during reactive hyperemia. 
LX-2 The results when the Doppler awdiospectra are recorded in the iliac arteries.

A comparison was made between the three methods used to detect aortoilliac disease, i.e. the Doppler technique, arteriography, and pressure measurements. In this evaluation arteriogyaphy and pressure measurements were used as references.

\section{IX-2-1 Comparison with arteriography}

In table II-5 a comparison is made between the results of the Doppler measurements in the iliac arteries and the degree of narrowing of the aortoiliac tree, as assessed on the anteriogram.

Table If-5. Doppler audiospectrum class, when the signal is recorded in the tiliac arteries, compared with the differend degrees of contoiliac stenosis, as assessed on the arieriogram.

\begin{tabular}{|c|c|c|c|c|c|c|c|c|}
\hline \multirow{3}{*}{ iliaca } & & \multicolumn{5}{|c|}{ Hortoiliac stenosis } & \multirow[b]{2}{*}{$100 \%$} & \multirow[b]{2}{*}{$N$} \\
\hline & & $0-9 \%$ & $10-39 \%$ & $40-49 \%$ & $50-69 \%$ & $70-99 \%$ & & \\
\hline & 1 & 12 & 8 & 1 & $\|$ & 0 & 0 & 22 \\
\hline \multirow{3}{*}{$\begin{array}{l}\text { audio } \\
\text { spectrum }\end{array}$} & III & 56 & 37 & 12 & 3 & 2 & 0 & 110 \\
\hline & III & 1 & 2 & 0 & 1 & 8 & 0 & 12 \\
\hline & IV & 1 & 2 & 5 & 10 & 16 & 1 & 35 \\
\hline \multirow{3}{*}{ class } & V & 0 & 1 & 1 & 2 & 6 & 2 & 12 \\
\hline & VII & 1 & 0 & 0 & $\mathbb{1}$ & 0 & 7 & 9 \\
\hline & & 71 & 50 & 19 & 18 & 32 & 10 & 200 \\
\hline
\end{tabular}

Figure II-14 and II-15 give a visual representation of the different groups. There is a clear regression in nomal audiospectra with increasing degree of stenosis. With increasing stenosis, the Doppler spectra become more pathological. 


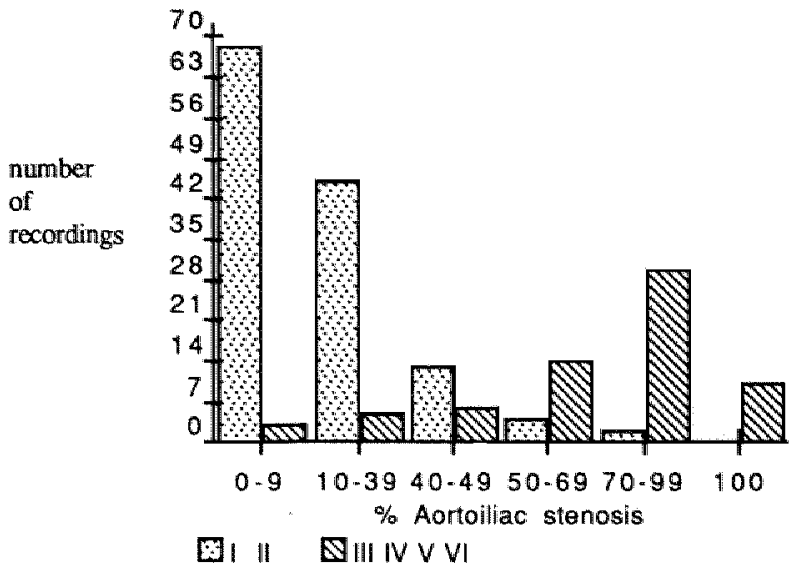

Fig II-14: Number of iliac recordings in the various Doppler classes, as compared with the different degrees of stenosis on the arteriogram.

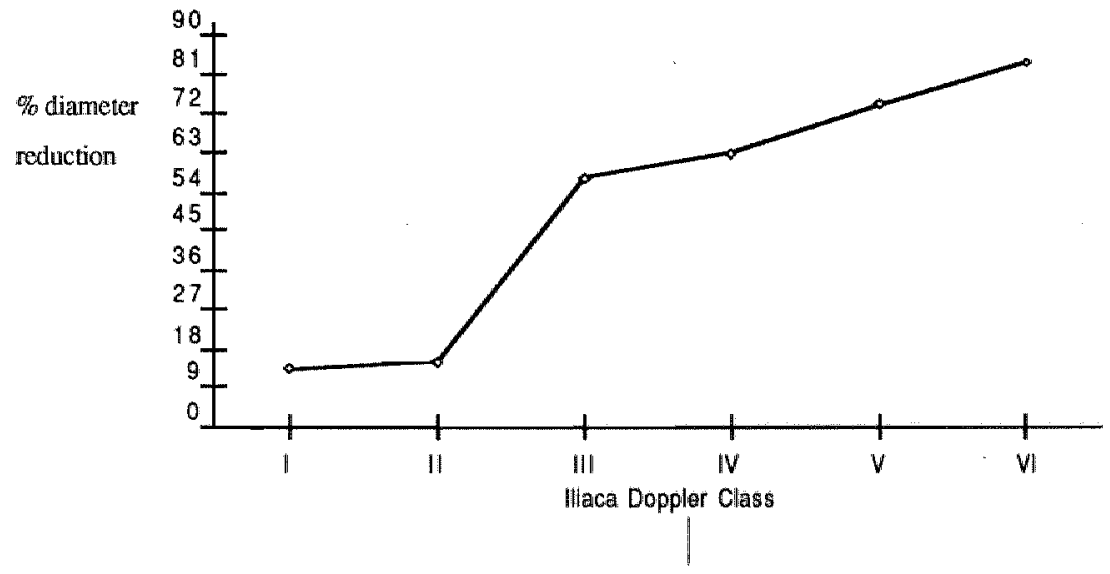

Fig. II-15: The mean \% diameter reduction, as assessed on the arteriogram, in the different iliaca Doppler audiospectrum classes.

If we use these results to determine sensitivity and specificity of the Doppler method, then the R.O.C. curve, as presented in fig II-16, is obtained. The optimal sensitivity/specificity value is shown at a $50 \%$ diameter reduction. 


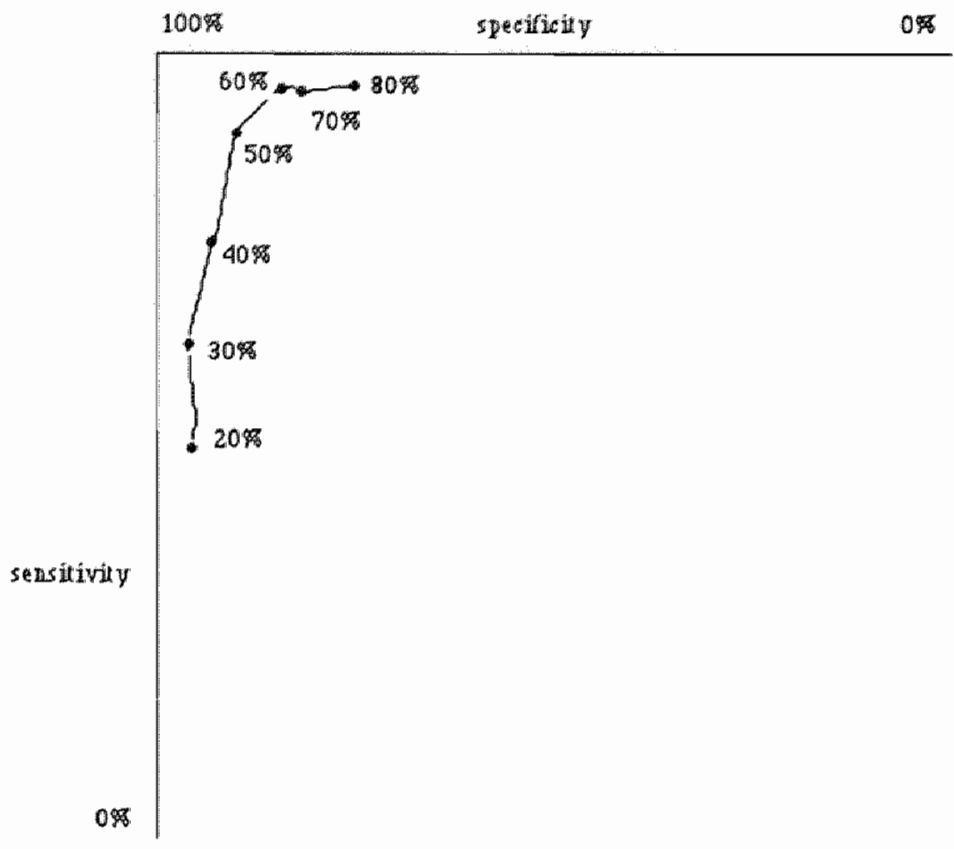

Fig. II-16: R.O.C. Curve comparing Doppler audiospectrum analysis with aortoiliac stenosis, as assessed on the arteriogram. The Doppler recordings are made in the illac arteries.

The differentiation between more or less than $50 \%$ diameter reduction gives a sensitivity of $90 \%$, a specificity of $90 \%$, a positive predictive value of $80 \%$, a negative predictive value of $95 \%$ and a diagnostic accuracy of $90 \%$. If we use the Doppler method for detecting stenoses of more or less than $40 \%$ diameter reduction the sensitivity is $76 \%$, the specificity $93 \%$, the positive and negative predictive value $88 \%$ and $86 \%$ respectively, and the diagnostic accuracy $86 \%$. It is obvious that in the group of $40-49 \%$ diameter reduction there is a wide variation of possibilities in the Doppler audiospectrum because :

- a particular stenosis in the arteriogram is not related to a certain hemodynamic involvement. Arteriography is a static observation. Doppler examinations give a flowrelated disturbance,

- it is difficult to precisely measure the \% diameter reduction of arteries. The image of an 
artery like the iliac artery has a diameter of $1,5 \mathrm{~cm}$ on the arteriogram. There is a great interobserver variability (Bruins Slot 1981) not only with single plane arteriograms, but also when biplane views are available (Chikos 1983, Flanigan 1983).

In detecting aortoiliac stenoses with mone or less than $50 \%$ diameter reduction the sensitivity and specificity of our Doppler method is $90 \%$ which is in good agreement with other non-invasive methods described in the literature (see discussion).

Another aim of this study was to examine whether our method could detect stenoses with a minor degree of narrowing, e.g. $40 \%$ diameter reduction. In the literature a $50 \%$ diameter reduction is the value between significant and non-significant stenoses. The sensitivity in detecting stenoses with a minor degree of narrowing declines. The sensitivity falls to $76 \%$ in detecting stenoses with more or less than $40 \%$ diameter reduction. However, the diagnostic accuracy of the test is still $86 \%$.

IX-2-2: Analysis of false negative and false positive results:

The false negative results are:

$\begin{array}{lrrrrr}\text { nir } & \text { Prest } & \text { Prh } & \text { Doppler class } & \text { go inflow stenosis } & \text { Proutflow stenosis } \\ 26 & 17 & 19 & \text { II } & 50 & 70 \\ 80 & 26 & 19 & \text { II } & 50 & 0 \\ 107 & 24 & 30 & \text { II } & 70 & 0 \\ 121 & 0 & 5 & \text { I } & 50 & 50 \\ 163 & - & - & \text { II } & 95 & 8 \\ 169 & - & - & \text { II } & 50 & 50\end{array}$

nr.: number of limb, P rest: \% pressure drop at rest, Prh: \% pressure drop during reacuive hyperemia; the Doppler recorditugs are made in the in

In case 21 only a slight pressure drop at rest and during reactive hyperefria was found, which was in accordance with the Doppler method. An outflow stenosis of $50 \%$ was round in the artenogram (occlusion of the superficial femora artery). With this patient a Dotter procedure of the iliac artery stenosis falled. It was successfully followed by a femoropolited bypass. It can be postulated in this case that the arteriogram overestimated the lesion. In the three other cases where pressure measurentents were perforned, an agreement between arteriogram and pressure measurements existed. 
The false positive results are:

\begin{tabular}{|c|c|c|c|c|c|}
\hline$p$ & Prost & Prh & Dopdicr class & in inflow stenosis & Tourfliow stenosis \\
\hline 29 & $\therefore$ & - & IN & 0 & 70 \\
\hline 33 & - & - & IV & 33 & 28 \\
\hline 35 & . & - & $\mathrm{V}$ & 40 & 50 \\
\hline 47 & 12 & 20 & III & 30 & 0 \\
\hline 105 & - & - & IN & 40 & 20 \\
\hline 119 & $\therefore$ & - & IN & 42 & 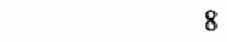 \\
\hline 137 & 24 & 22 & IV & 35 & 0 \\
\hline 140 & 35 & 33 & 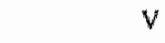 & 35 & 0 \\
\hline 152 & - & - & III & 10 & 100 \\
\hline 175 & - & - & VI & 0 & 0 \\
\hline 191 & 14 & 37 & IV & 45 & 0 \\
\hline 195 & - & - & IV & 40 & 0 \\
\hline 197 & 6 & 9 & IV & 40 & 91 \\
\hline 199 & 3 & 8 & III & 0 & 5 \\
\hline
\end{tabular}

nr.: number of limb, Prest: $\%$ pressure drop at rest, Prh: \% pressure drop during reactive hyperemia; the Doppler recordings are made in the illac arteries.

In 10 out of these 14 cases, the degree of aortoiliac stenosis found in the arteriogram was $\geq 30 \%$, and in $6 \geq 40 \%$. In 4 out of these 10 cases (viz. $47,137,140$ and 191 ), an important pressure drop was found at rest as well as during reactive hyperemia. No outflow stenosis could be detected in these cases.

In the remaining 4 cases the degree of aortoiliac stenosis found on the arteriogram was $\leq 10 \%$. In 3 out of these 4 cases, 29,152 and 199, there was an important outfiow stenosis.

Four of the false positive results are in accordance with the results of the pressure tests. It was possible to detect these 10 stenoses, since they gave rise to the flow velocity disturbances detected by the Doppler audiospectrum. It therefore can be concluded that there are only 4 real false positive cases.

IX-2-3 Comparison with pressure measurements

In the 200 limbs which are the subject of this study, 85 pressure recordings at rest and 83 recordings during reactive hyperemia were performed. The pressure drop at rest is the difference between the aortic pressure and the common femoral artery pressure 
expressed by way of percentage. The pressure drop during reactive hyperemia the difference between the pressure in the common femoral artery after a five mimutes occlusion of flow in the limb using a compression cuff, and the pressure at the same point before cuff release. The difference is expressed by way of percentage. Both results are relative values and independent from each other.

IX-2-3-1 Arteriography and pressure measurements

The results of the pressure measurements cannot only be compared with the results of our Doppler method, but also with those obtained with biplane arteriography.

In figure $11-17$ the mean \% pressure drop at rest and during reactive hyperemia is shown as a function of the degree of stenosis. Only after a diameter reduction of more than $50 \%$ there is an increase in pressure drop at rest and during reactive hyperemia.

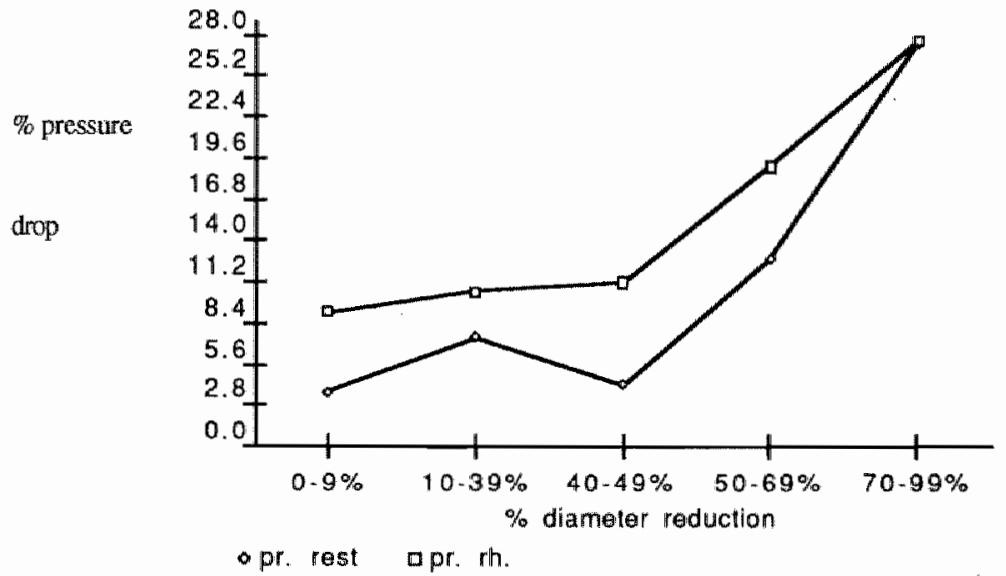

Fig. 11-17: Mean \% pressure drop as a function of the degree of aortoiliac stenosis, as assessed at arteriography

In fig. M-18 the mean \% pressure drop at rest with standard deviation is shown for each group of aortoiliac stenosis, as assessed in the arteriogram. 


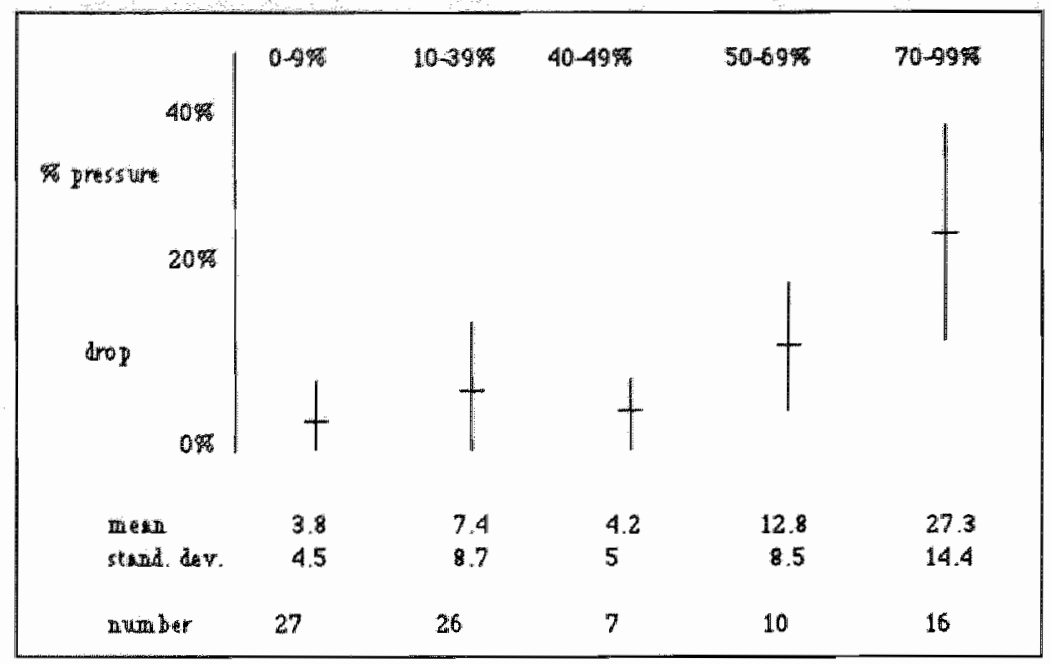

Fig. 1/. 19: Mean values and siandard dewiations of \% pressure drop at rest, as compared with the different groups of aorloiliac stenoxis, as assessed in the arteriogrant.

In fig II-19 the mean values and the standard deviations of the $\%$ pressure drop during reactive hyperemiat for each stenosis group is shown. As for the results obtained at rest the pressure measurements made in limbs with a stenosis of $40-49 \%$ on the arteriogram, are statistically not significantly different from those made in limbs with stenoses $<40 \%$.

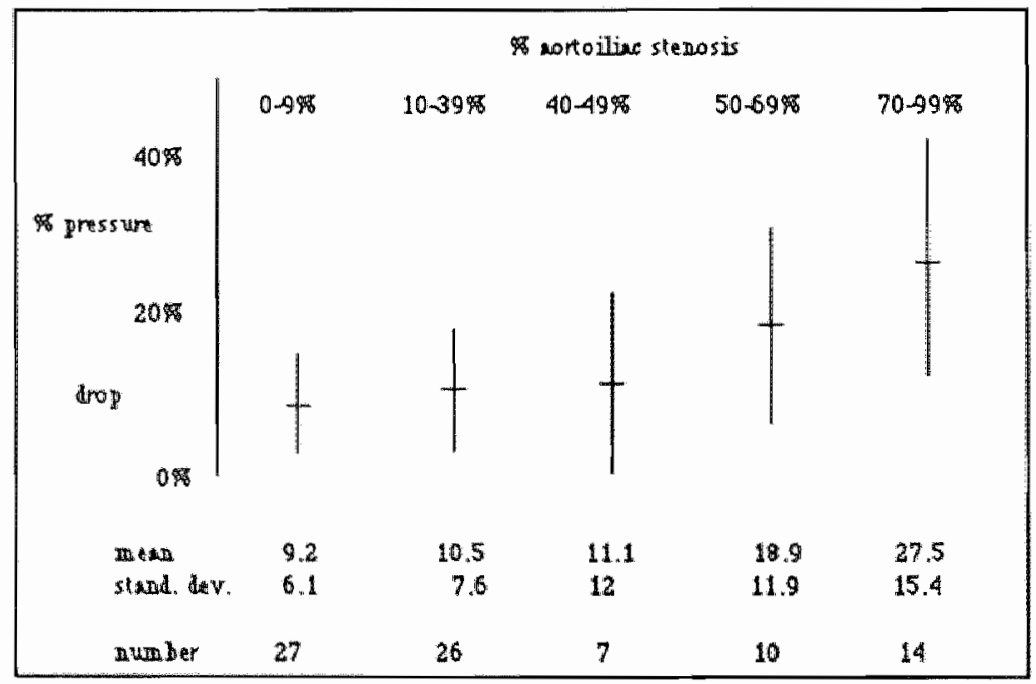

Fig. II-19: Mean of pressure drop wallues and standard deviations during reactive hyperemio and the different groups of aortoiliac stenosis, as assessed in the arteriogram. 
In both figures (II-18 and II-19) there is only a statistical difference in the group 70 . $99 \%$ diameter reduction (Pearson chi-square $\mathrm{p}<0.001$ ). The other groups are not significantly different from each other.

\section{IX-2-3-2 Doppler tests and pressure measurements:}

In fig II-20 the results of the pressure measurements at rest and during reactive hyperemia are compared with those of the Doppler tests performed in the iliac arteries. With one patient no signal could be recorded (class VI). This was due to the obesity of the patient. Therefore, 85 recordings at rest and 83 during reactive hyperemia are used in the comparison with the iliac Doppler results. An increase in $\%$ pressure drop is seen with an increase in severeness of the disease, as estimated on the basis of the Doppler classification. No difference is seen between pressure measurements at rest and during reactive hyperemia.

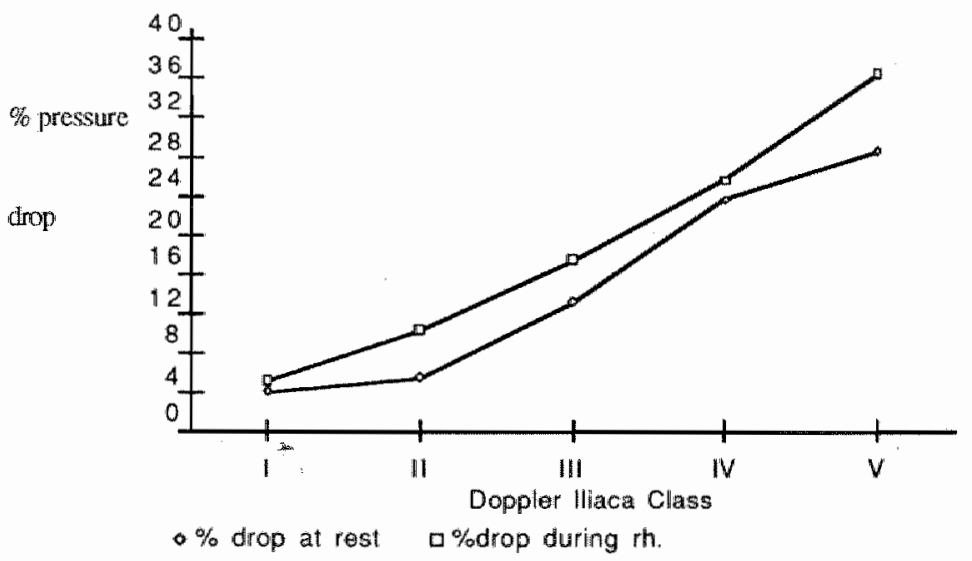

Fig. 11-20: Mean \% pressure drop at rest and during reactive hyperemia in each Doppler audiospectrum class; the Doppler recordings being made in the iliac artery.

In fig. II-21 the mean pressure drop values at rest and the standard deviations are shown in each iliac Doppler audiospectrum class. There is a significant difference between Doppler class I and II on the one hand and the groups III, IV and V on the other $(\mathrm{p}<0.001)$. 


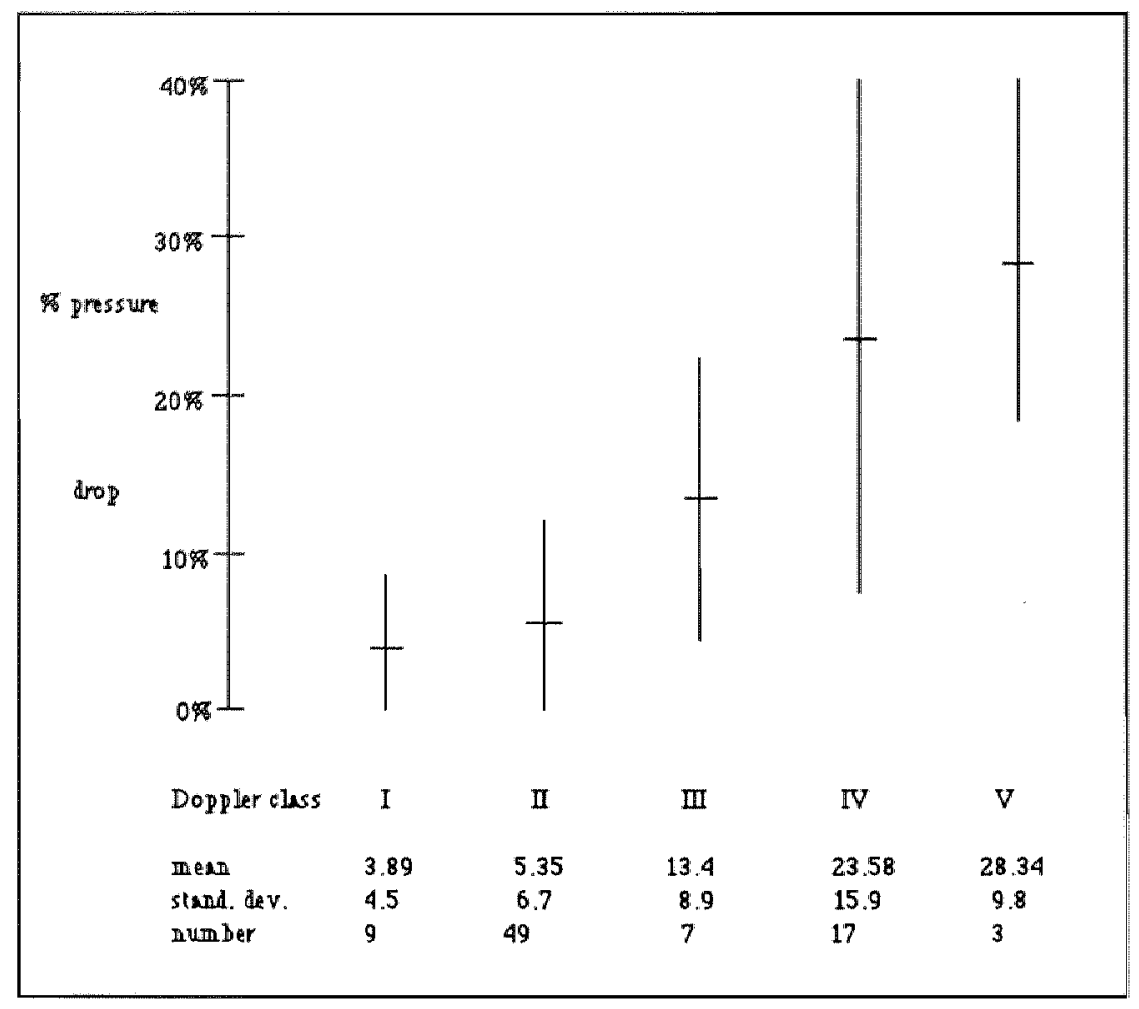

Fig. 11-21: Mean \% pressure drop values at rest and the standard deviarions in each Doppler audiospectrom class; the Doppler recordings being made in the vilac artery.

In fig. II-22 a R.O.C. curve is shown based upon the results of pressure measurements at rest. The best sensitivity/specificity results are obtained at a cut-off point of $12 \%$ pressure drop. 


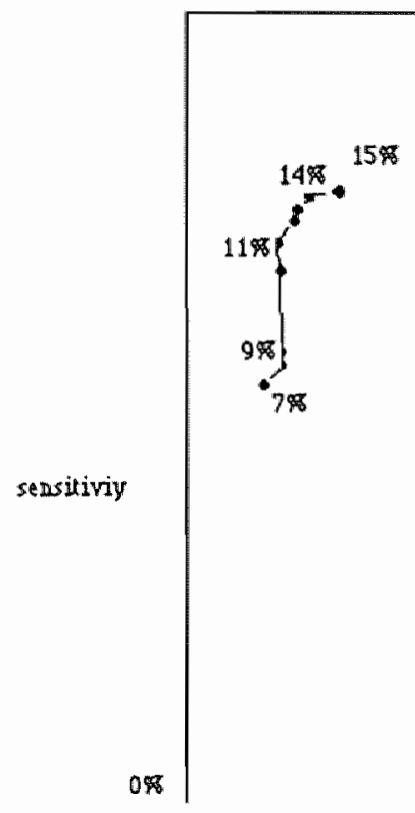

Fig. II-22:R.O.C. Curve Comparing the \%pressure drop at rest with Doppler andiospectrum analysis; the Doppler recordings being made in the iliac artery.

The mean values and standard deviations of the pressure measurements during reactive hyperemia are shown in figure II-23. As for the pressure measurements at rest there is a significant difference between Doppler class I and II on the one hand and the other Doppler classes on the other $(p<0.001)$ 


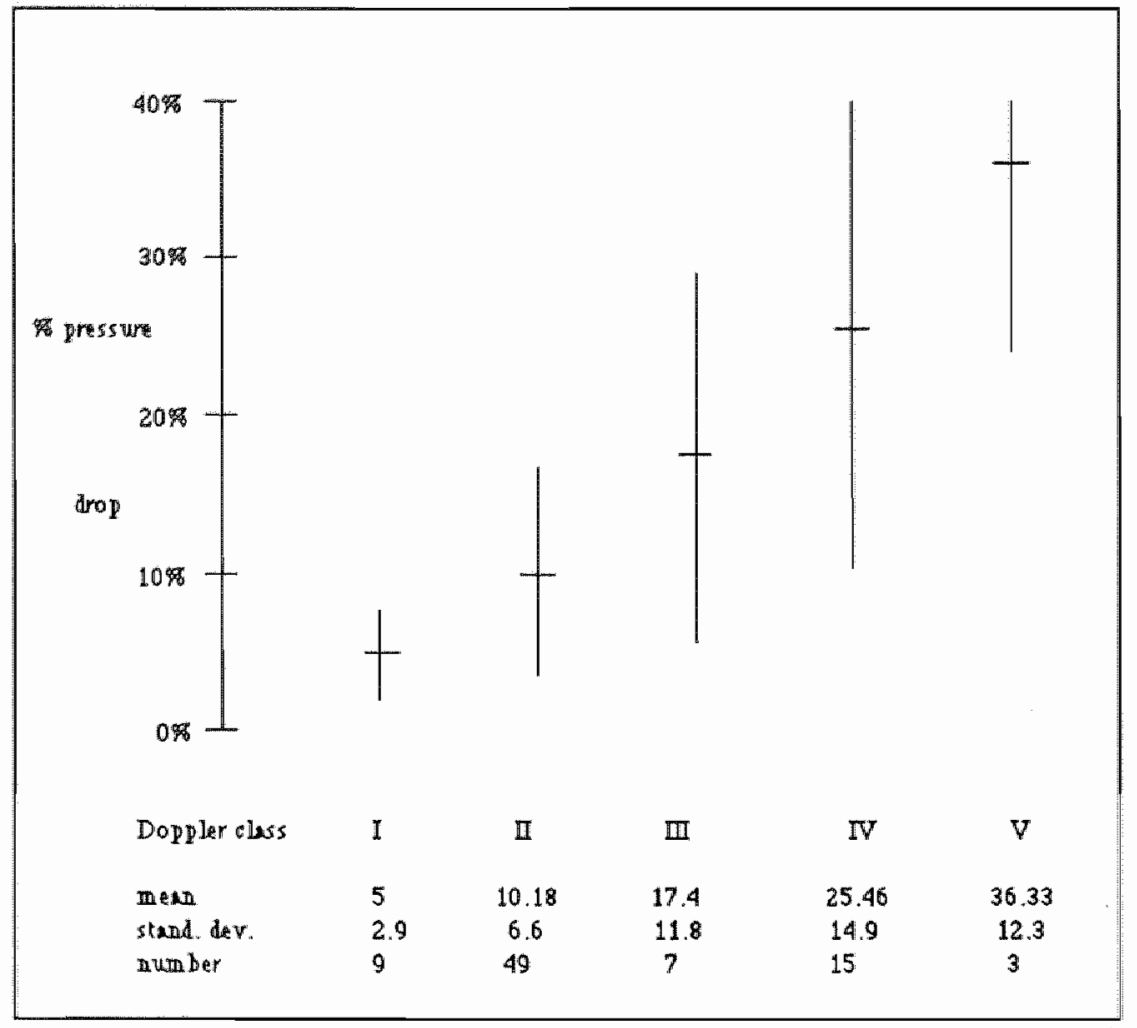

Fig. 11-23: Mean pressure drop wallues during reactive hyperemia and the standard dewiations in each Doppler audiospectum class; the Doppler signals being recorded in the iliac artery.

Expressed in the R.O.C. curve (fig. Ir-24) the sensitivity and specificity are maximal at a pressure drop of $20 \%$ during reactive hyperemia. 


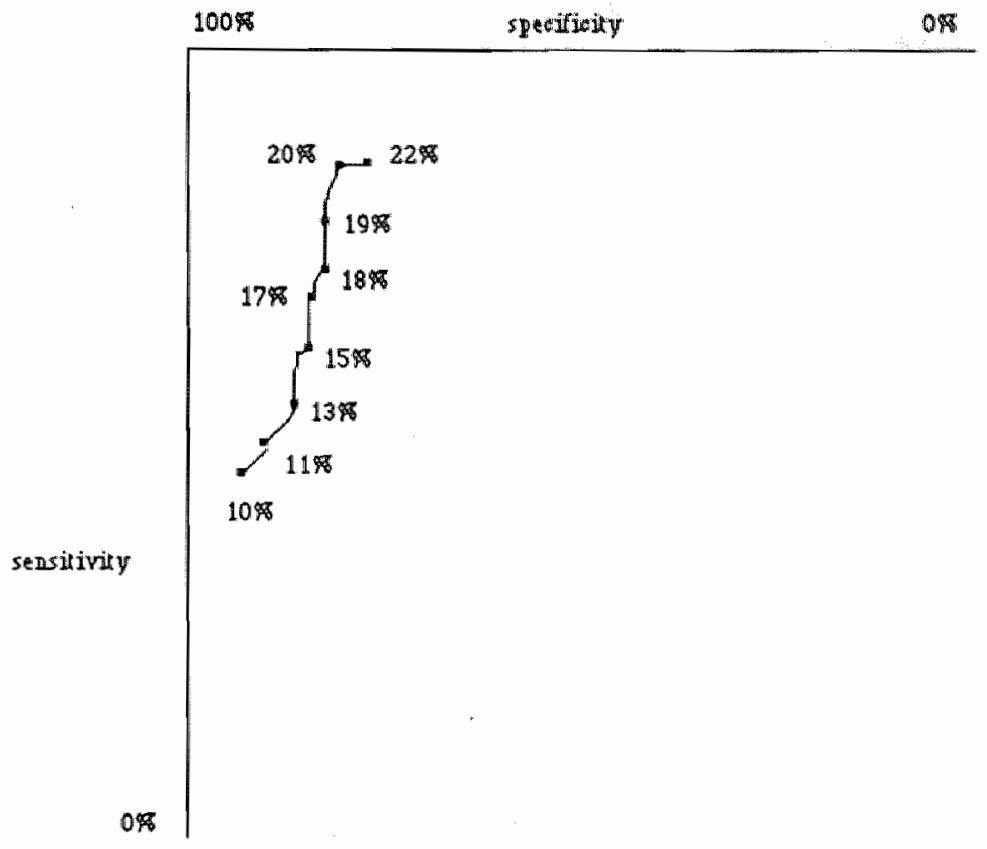

Fig II-24:R.O.C. curve comparing the \% pressure drop during reactive hyperemia with Doppler audiospectrum analysis; the Doppler signals being recorded in the iliac arteries.

If we do consider a pressure drop at rest of more than $12 \%$ as indicative of a hemodynamically importânt lesion, then the following decision matrix (table II-6) is obtained

Table II-6: Sensiniwityspecificity decision matrix comparing the Doppler categories III through $V$, and I and I/ with a \% pressure drop at rest of $>$ or $\leq 12 \%$.

\begin{tabular}{llrrr|}
\hline & & $>12 \%$ & $\leq 12 \%$ & Total \\
\cline { 3 - 5 } Doppler & III-IV-V & 18 & 9 & 27 \\
Test & I-II & 7 & 51 & 58 \\
\hline & & 25 & 60 & 85 \\
\hline
\end{tabular}




$\begin{array}{ll}\text { sensitivity } & 72 \% \\ \text { specificity } & 85 \% \\ \text { positive predictive value } & 67 \% \\ \text { negalive predictive value } & 88 \% \\ \text { diagnostic accuracy } & 81 \%\end{array}$

The diagnostic accuracy of the Doppler test, in detecting an aortoiliac pathway stenosis with a pressure drop of $>12 \%$ as indication of an important hemodynamic lesion, is only $81 \%$.

If we consider a pressure drop during reactive hyperemia of more than $20 \%$ as significant for a hemodynamically important lesion, then the results shown in table II-7 are obtained.

Table 1/-7: Sensitivitydspecificity decision matrix comparing the Doppler categaries III through $V$, and I and II with a to pressure drop during reactive hyperemia of $>$ or $\leq 20 \%$

\begin{tabular}{|c|c|c|c|c|}
\hline \multirow{2}{*}{\multicolumn{2}{|c|}{ Doppler III-IV'V }} & $>20 \%$ & $\leq 20 \%$ & Total \\
\hline & & 12 & 13 & 25 \\
\hline \multirow[t]{2}{*}{ test } & 1-II & 2 & 56 & 58 \\
\hline & & 14 & 69 & 83 \\
\hline
\end{tabular}

$\begin{array}{ll}\text { sensitivity } & 86 \% \\ \text { specificity } & 81 \% \\ \text { positive predictive value } & 48 \% \\ \text { negative prediclive value } & 96 \% \\ \text { diagnostic accuracy } & 82 \%\end{array}$

The diagnostic accuracy of the Doppler test in derecting lesions in the aortoiliac pathway associated with a pressure drop during reactive hyperemia of $>20 \%$, is only $82 \%$, an accuracy not significantly different from that obtained when using the pressure drop at rest.

Both pressure tests can also be combined. We can take a $12 \%$ pressure drop at rest and a $20 \%$ pressure drop during reactive hyperemia as the reference value. The combined pressure test can be considered as positive if at rest the pressure drop is $\geq 12 \%$ and during reactive hyperemia $\geq 20 \%$. In 83 limbs both pressure tests were performed. The 
sensitivity/specificity decision matrix, as obtained in this way, is presented in table II-8.

Table II-8: Sensitivity/specificity decision matrix comparing the Doppler categories Wh through $\mathrm{V}$, and I and $I$ with the combined pressure test.

\begin{tabular}{|lrrrr|}
\hline & \multicolumn{4}{c|}{ Combined pressire test } \\
\cline { 3 - 5 } Doppler & III-IV-V & + & 12 & Total \\
\cline { 3 - 5 } Test & I-II & 13 & 56 & 25 \\
& & 2 & 68 & 83 \\
\cline { 3 - 5 } & & 15 & & 83 \\
\hline
\end{tabular}

$\begin{array}{ll}\text { sensitivity: } & 87 \% \\ \text { specificity: } & 81 \% \\ \text { positive accuracy: } & 52 \% \\ \text { negative accuracy: } & 96 \% \\ \text { diagnostic acuracy:: } & 83 \%\end{array}$

The diagnostic accuracy of the Doppler test, representative of an important lesion in the aortoiliac pathway, is $83 \%$ when the combined pressure test is positive. This result is the same as for each pressure test separately. 
WX-2-3-3 Detalled analysis of the false positive and false negative results in the combined pressure test:

The false positiwe results in the combined tests are:

\begin{tabular}{|c|c|c|c|c|c|}
\hline 距 & Presl & Peth & class & oplenose & reconsturiction \\
\hline 1 & 19 & 14 & III & 75 & iliace reconstruction \\
\hline 12 & 14 & 14 & III & 70 & Diac dotuer + profundaplasty \\
\hline 39 & 9 & 11 & N & 60 & aortoiliac reconstruction + femoral dotter \\
\hline 84 & 3 & 3 & IV & 50 & femoral reconstruction \\
\hline 90 & 7 & 19 & N & 75 & iliac dotter \\
\hline 113 & 11 & 44 & IV & 75 & iliac dotter \\
\hline 125 & 11 & 11 & आII & 77 & iliac dotter \\
\hline 149 & $3 !$ & 17 & IV & 85 & aortoiliac reconstruction \\
\hline 154 & 39 & 10 & IV & 95 & aortoiliac reconstruction \\
\hline 186 & 4 & 12 & III & 50 & antoiliac + femoral reconstruction \\
\hline 197 & 6 & 9 & IV & 40 & no reconstruction performed \\
\hline 199 & 3 & 8 & III & $0 \%$ & femoral reconstruction \\
\hline
\end{tabular}

nr.: number of limb in the study: Prest: \% pressure drop at rest; Prh: \% pressure drop during reactive

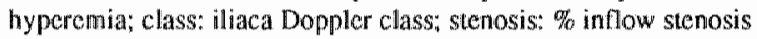

In the cases $1,12,113,149$ and 154 the pressure test at rest or the pressure test during reactive hyperemia strongly suggested the presence of an important lesion. Except for the cases 197 and 199, all Doppler tests were in agreement with the degree of stenosis seen in the arteriogram. "Therefore, the so-called false positivity was generally due to failure of the combined pressure test.

case 39 :

The Doppler result was in agreement with the arteriogram. A pressure drop of $9 \%$ at rest and $11 \%$ at reactive hyperemia was found. There was an occlusion of the superficial femoral artery. After performing a proximal and distal reconstruction complete relief of the symptoms was seen. The too low pressure drop for the severeness of the disease might have been caused by the occlusion of the femoral artery. This phenomenon will be discussed in section $\mathrm{IX}-1-3-3$. In this case the pressure tests failed to indicate the hemodynamically significant stenosis.

case 84 :

The Doppler test was in agreement with arteriography, but there were no significant pressure drops. Also in this case there was an occlusion of the superficial femoral artery. A distal reconstruction (femorotibial bypass) failed twice and resulted in amputation. 
case 90 :

The Doppler test was in agreement with a significant stenosis on the arteriogram. A pressure drop of $19 \%$ during reactive hyperemia was found, which is just below the $20 \%$ we postulated. There was no significant stenosis distally. A proximal Dotter procedure gave excellent results.

case 125:

The Doppler test was in agreement with the arteriographic findings. A pressure drop at rest and during reactive hyperemia of $11 \%$ was below our postulated values, but is indicative of a significant stenosis. There was no significant stenosis distally. After a proximal Dotter procedure was performed, the clinical (subjective) result was onlly moderate. For this case all techniques would have been in agreement if we had considered a pressure drop at rest of $11 \%$ as significant. case 186 :

The Doppler test was indicative of an inflow stenosis of $50 \%$. Nevertheless there was only a slight pressure drop at rest ( $4 \%$ ) and a more distinct pressure drop during reactive hyperemia (12\%). There was an occlusion of the superficial femoral artery. The patient underwent an aortoiliac reconstruction followed by a peripheral reconstruction. The reason for failure of the pressure tests may be the occlusion of the superficial femoral artery.

case 197 :

A stenosis of $40 \%$ was found on the arteriogram without a significant pressure drop. The Doppler test was indicative of a significant lesion. There was an occlusion of the superficial femoral artery. Although a positive Doppler test was found no therapy was performed.

case 199:

The Doppler test was in disagreement with both arteriography and the pressure measurements. An aneurysmal dilatation of the iliac artery was found. There was also an occlusion of the superficial femoral artery. With this patient the distal reconstruction failed due to an infection of the prosthesis.

Flow in aneurysmatic dilated arteries is more complex. There was no stenosis, but the flow disturbance induced an abnormal Doppler spectrum, suggesting the presence of a significant degree of artery narrowing. 
The false negative results are:

$\begin{array}{lrrrrl}\text { 12r } & \text { Pest } & \text { Pin } & \text { dass } & \text { sienose } & \text { reconstuction } \\ 51 & 20 & 20 & \text { II } & 30 \% & \text { no reconistruction performed } \\ 107 & 24 & 30 & \text { II } & 70 \% & \text { iliac dotter }\end{array}$

nr: number of limb in the study; Prest: $\%$ pressure drop at rest; Prh: $\%$ pressure drop during reactive hyperemia class; iliaca Doppler class; stenosis: \% inflow stenosis

case 51 :

There was a disagreement between the Doppler tests and arteriography (30\% stenosis) on the one hand, and the pressure tests on the other. No distal stenosis existed. No reconstruction was perfomed. Therefore, there actually are no false negative result as far as the Doppler test is concenned.

case 107:

There was a complete miscliagnosis with the Doppler test. Both arteriography and the pressure tests were indicative of a significant stenosis. No distal stenosis existed. A proximal Dotter procedure was followed by excellent results. The stenosis was at the origin of the common iliac artery. The Doppler probably did not reach as proximally in this patient.

\section{IX-2-3-4 Discussion:}

Only in one case (107) the Doppler technique failed to indicate an important lesion which was diagnosed by both arteriography and pressure tests. In 10 out of 12 false positive cases, the results of the Doppler examinations performed in the iliac arteries were in accordance with the results in the arteriogram. (\% diameter reduction $\geq 50 \%$ ). In those cases, there was a minor pressure drop at rest or during reactive hyperemia, or both. "The false positivity is due to the inability of the pressure tests to diagnose the lesions. In case 197 a Doppler audiospectrum class IV was found and an aortoiliac obstruction with a $40 \%$ diameter reduction on the arteriogram. In case 199 the pressure tests were in agreement with the results of the arteriogram. In four cases $(39,84,86$ and 197), in which the combined pressure test failed, an aortoiliac obstruction of $>40 \%$ with complete obstruction of the superficial femoral artery was seen. This observation raises the question as to whether complete obstruction of the superficial femoral artery significantly influences the results of the pressure measurements in the aortoiliac pathway. Therefore, the legs, in which there is an inflow and outflow stenosis of $\geq 50 \%$, were examined in more detail. 
7 Pressure tests were performed in legs with an inflow and outflow stenosis of $>50 \%$. In 4 (39-84-121-186) of the 7 cases, which were ascociated with complete obstruction of the superficial femoral artery, there was only a small pressure drop at rest and during reactive hyperemia. In the 3 other cases the combined pressure test failed (table II-9). In those cases pressure is measured between two important stenoses. An important pressure drop distal to both stenoses, for instance at the site of the ankle, can be expected. Ankle pressure measurements were performed non-invasively as a routine with many patients having vascular complaints. The results of these measurements are shown in table II-9. For limb 84 no ankle/arm index was available.

Table 17-9. Limbs whinflow and outfow stenoses of $>50 \%$ in which non-inwasive pressare measurements were performed and ankle/arm indices at rest are available.

\begin{tabular}{|lrrr|}
\hline nr. limb & \&P rest & \%P.rh. & ankle/arm index (rest) \\
\hline 1 & 19 & 14 & 0.5 \\
12 & 14 & 14 & 0.6 \\
26 & 17 & 19 & 0.9 \\
39 & 9 & 11 & 0.6 \\
121 & 0 & 5 & 0.6 \\
186 & 4 & 12 & 0.4 \\
\hline
\end{tabular}

The ankle/arm index at rest in this group is $0.6+/-0.167(\mathrm{x}+/-\mathrm{sd})$. In all cases exept for case 26 the ankle/arm index at rest is $\leq 0.6$.

We can compare these results with legs in which there is an inflow stenosis of $>50 \%$ without outflow stenosis and in which an ankle/arm index was available. In Table II-10 the legs, in which pressure measurements were performed, are summarized. In two legs the ankle/arm index at rest is 0.5 . In six cases the index is $\geq 0.7$. 
Table II-10: Limbs wilh inflow stenosis of $>90 \%$ without outhow steroxis, in which non-invasive pressure whedurements were performed and ankle arm indices at rest are available.

\begin{tabular}{|lrrr|}
\hline nr. limb & \% Prest & \% Pr.h. & ankle/arm index (rest) \\
\hline 19 & 16 & 34 & 0.7 \\
31 & 18 & 32 & 0.8 \\
80 & 26 & 19 & 0.7 \\
93 & 62 & 57 & 0.7 \\
107 & 24 & 30 & 0.7 \\
149 & 31 & 17 & 0.9 \\
151 & 47 & - & 0.5 \\
183 & 33 & 20 & 0.5 \\
\hline
\end{tabular}

The ankle/arm index at rest is $0.7+/-0.14(x+/-$ sd).

Pressure measurements are performed in the femoral artery. In case of an outfow stenosis (situation 1) the point of measurement is between two important lesions. In the absence of a significant outflow stenosis (situation 2) the pressure is measured distal to one important stenosis. These situations are schematically depicted in figure II-25.

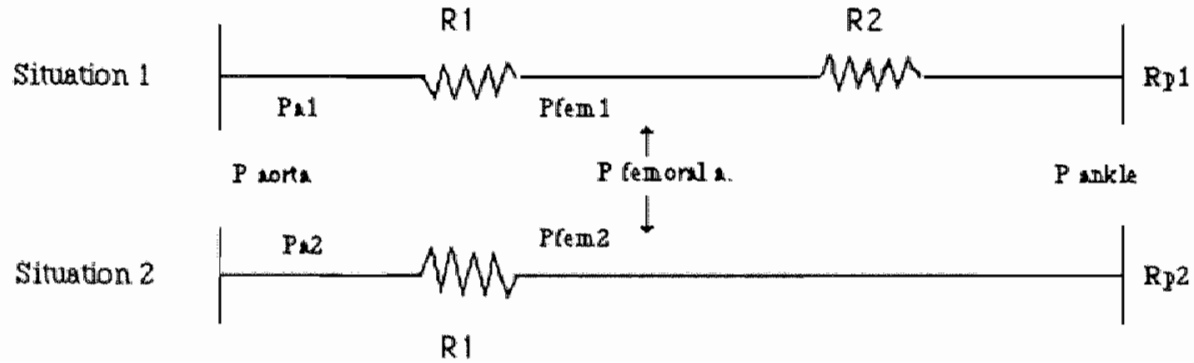

Fig. 17-25: Schemancal representanion of the pressure measturements with (situation l) and without (rituation 2) an ouffow stenosis.

Using Ohm's law as applied to haemodynamics (Fig. 11-25) the femoral pressure relative to the aorta pressure can be expressed as:

$$
\begin{array}{lll}
\mathrm{Pfem} 1 / \mathrm{Pa} 1 & =(\mathrm{R} 2+\mathrm{Rp} 1) /(\mathrm{R} 1+\mathrm{R} 2+\mathrm{Rp} 1) \\
\mathrm{Pfem} 2 / \mathbb{P a}_{2} & =\mathrm{Rp} 2 /(\mathrm{R} 1+\mathrm{Rp} 2)
\end{array}
$$

Assuming that in both situations the aorta pressure is in the same order Pfeml will be 
greater than Pfem2 for those cases where the stenosis resistance leads to a reduced volume flow (the pressure drop over R1 will be smaller). Moreover, the pressure drop over the stenoses (either R1 or R1+R2) causes a low ankle / amn index. A reduction in volume requires a reduction in peripheral tissue or a lower metabolism. Since the peripheral resistance is already close to its minimum, application of reactive hyperemia will augment the flow only slighly to moderately. As can be concluded from table II-9 this situation can be applied for all the cases listed; it should be noted that for subject 26 the ankle / arm index is exceptionally high.

These observations indicate that the pressure measurements are unreliable with regard to the presence of an occlusion of the superficial femoral artery.

DX-3 Evaluation of the clinical parameters

LX-3-1 Thigh claudication / Calf claudication

Thigh claudication was described as a symptom of aortoiliac stenosis. Several patients with thigh claudication are relieved from symptoms after an aortoiliac operation. Therefore, thigh claudication is considered as a complaint with patients having aortoiliac stenosis.

Table II-11: Decision matrix describing the comparison of thigh claudication with the different Doppler spectrum classes. The Doppler signals being recorded in the iliac artery.

\begin{tabular}{|lccr|}
\hline & \multicolumn{3}{c|}{ thigh claudication } \\
Class & yes & no & total \\
\cline { 2 - 4 } III-IV-V-VI & 31 & 37 & 68 \\
I-IT & 16 & 116 & 132 \\
\cline { 2 - 4 } & 47 & 153 & 200 \\
\hline
\end{tabular}

As shown in table II-11 in the group of patients with aortoiliac disease the chance of having thigh claudication is about even. The sensitivity of Doppler examinations to detect thigh claudication is $66 \%$, the specificity is $76 \%$, the positive predictive value is $45 \%$, the negative predictive value is $88 \%$, and the diagnostic accuracy is $73 \%$.

In figure II-26 the presence or absence of thigh claudication is compared to the \% diameter reduction in the arteriogram. The difference between both groups is statistically significant $(\mathrm{p}<0.001)$ 


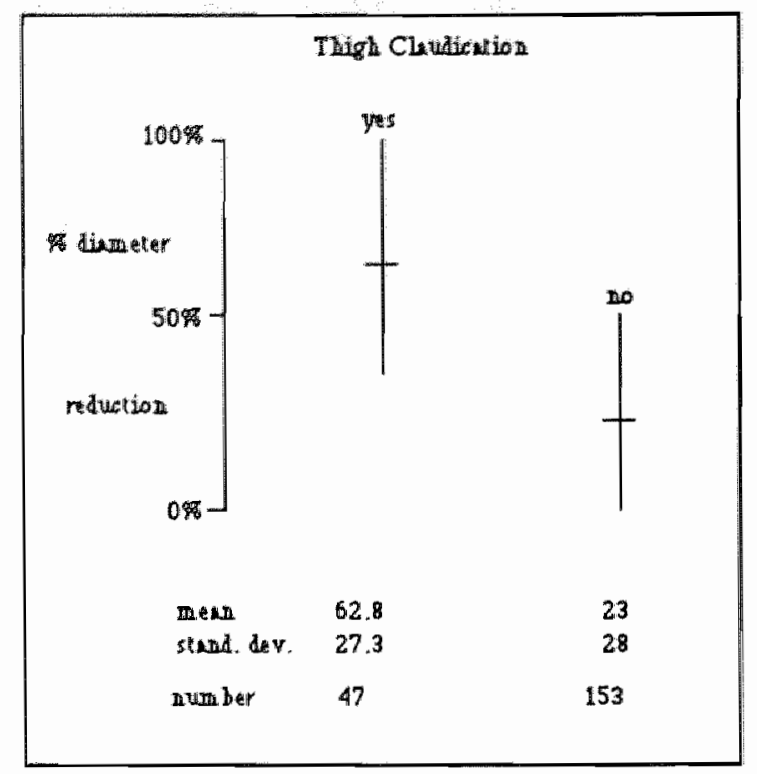

Fig. 11-26: Mean of diameter reductions on the arieriogram and standard deviations in the presence and absence of thigh claudication

Figure II- 27 and figure II-28 represent the pressure drop at rest and during reactive hyperemia, respectively, in limbs with thigh claudication. There is an important overlap between the data. Nevertheless the chance of finding a more significant pressure drop is greater with patients having complaints of thigh claudication $(p<0.005)$.

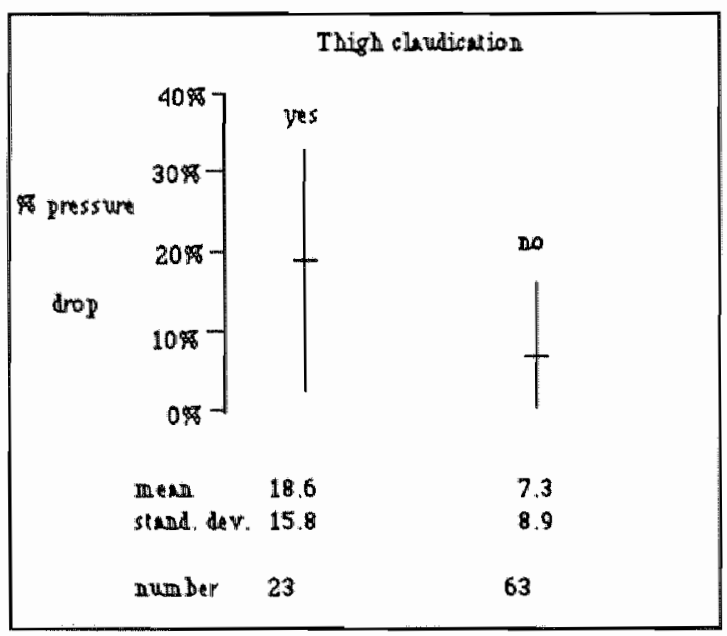

Fig. 11.27: Mean \% pressure drops and standard deviations ar rest in the presence or absence of thigh claudication. 


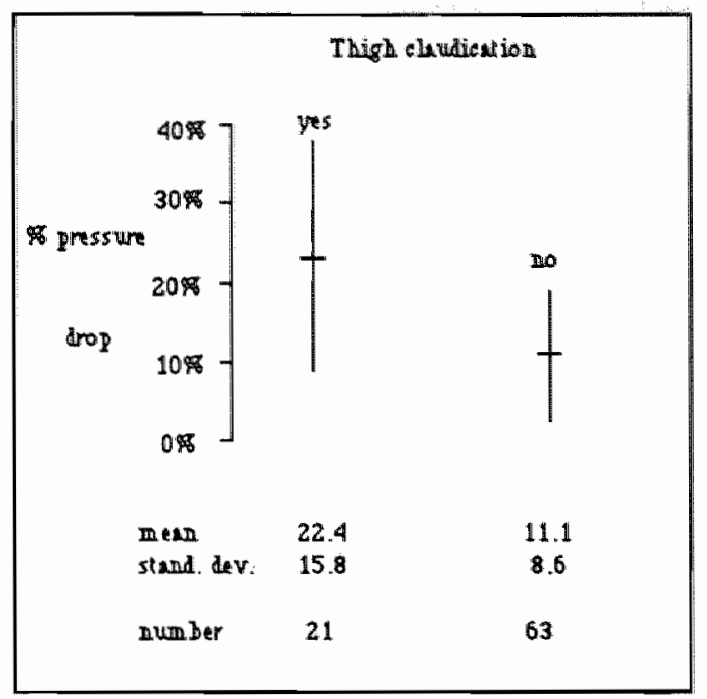

Fig. If-28: Mean \% pressure drops and stondard deviations during reactive hyperemia in the presence or absence of thigh claudication.

Unlike thigh claudication, calf claudication is a symptom referring to an arterial lesion without clear relation to its localization. Stenosis in the aortoiliac pathway, the femoropopliteal pathway, or in both pathways can cause calf claudication. The absence or presence of calf claudication gives no information about the state of the arterial tree. The pressure drops measured at rest and during reactive hyperemia are similar in the group with and without calf claudication.

\section{XX-3-2 Femoral artery pulse:}

Three different classes were distinguished : absence of the pulse $(0)$, a weak pulse $(+)$ or a normal pulse $(++)$. It is obvious that scoring femoral pulses as weak or nomal is difficult and subjective. Nevertheless when they are performed by the same examinator, they may have some relevance. Besides, the absence of a pulse at the site of the femoral artery is often seen in the presence of an important aortoiliac lesion.

In table II-12 an enumeration is given of the different iliac Doppler classes in relation to the quality of the pulse. In case of an absent pulse there was only one out of 16 cases with a Doppler class I or II. This was due to the obesity of the patient. In the cases with a weak pulse various Doppler patterns were found. 
Table 11-12. Differentiation in arteriat pulse in the differend Doppler classes. The Doppler signals being recorded in the flicas artery.

\begin{tabular}{|rrrrr|}
\hline & \multicolumn{5}{c}{ pulse } \\
H.II & absent & wealk & normal & total \\
\cline { 2 - 5 } MI.V.V.V.VI & 1 & 28 & 103 & 132 \\
& 15 & 27 & 26 & 68 \\
\cline { 2 - 5 } & 16 & 55 & 129 & 200 \\
\hline
\end{tabular}

In figure 11.29 the qualification of the femoral artery pulse is compared with the degree of aontoiliac stenosis, as assessed in the arteriogram. There is a statistically significant difference between the groups $(\mathrm{p}=0.04)$. Absence of the pulse corresponds to severe aortoiliac stenosis (a mean diameter reduction of $86 \%$ ).

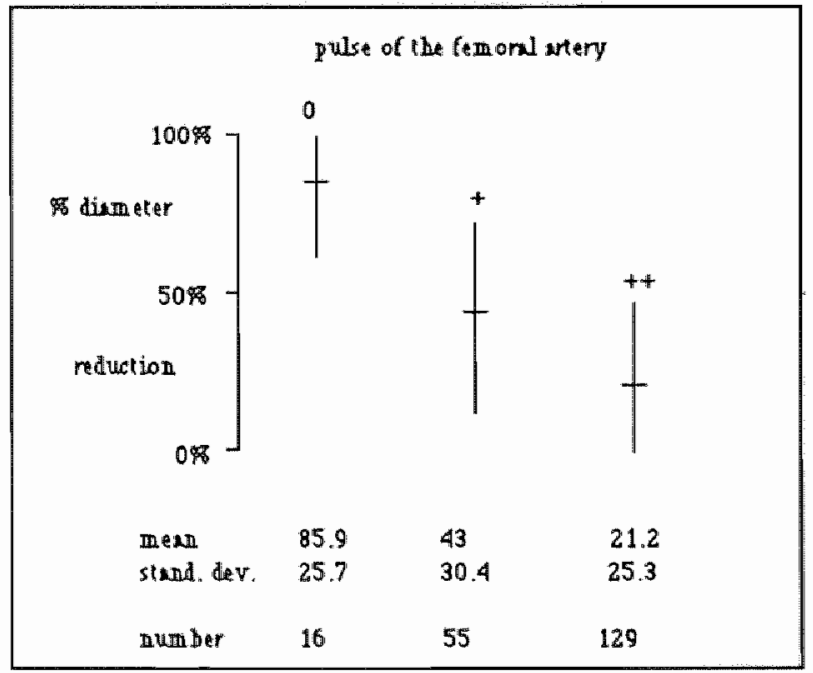

Fig. 11-29: Mean degree of "stenosis and standard deviation in the different arterial pulsation groups.

In the figures II-30 and II-31 qualification of the arterial pulse is compared with pressure measurements at rest and during reactive hyperemia, respectively. Both at rest ( $\mathrm{p}$ $=0.02)$ and during reactive hyperemia $(p=0.04)$, there is a significant difference batween weak and normal pulsations. 


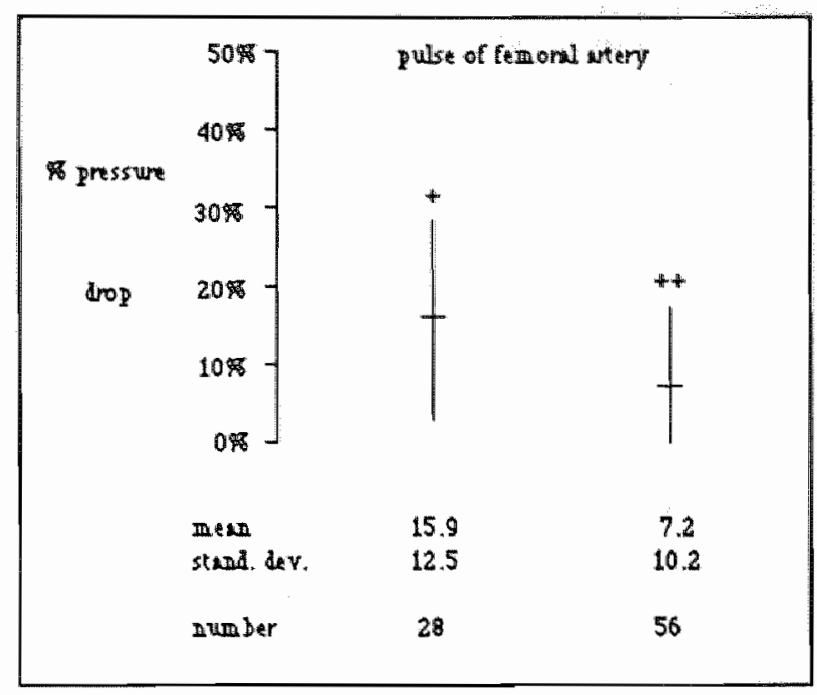

Fig. II-30: Mean pressure drops and standard deviations at rest in weak and normal pidsations of the femoralartery.

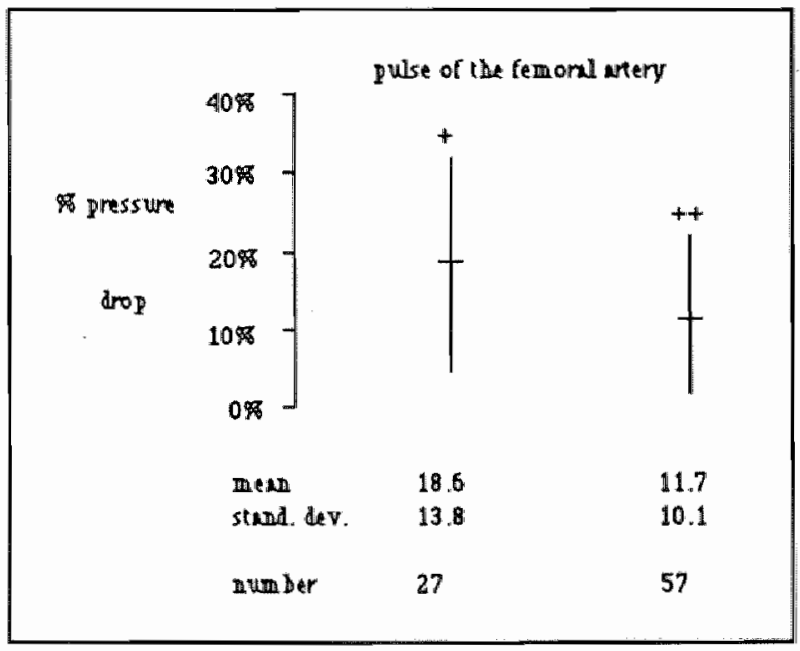

Fig. II-3I: Mean \% pressure drops and standard deviations during reactive hyperemia in weak and normal pulsations of the femoral artery.

\section{IX-3-3 Femoral bruit}

An arterial bruit is caused by vibrations in the audiorange. These vibrations are not always caused by flow disturbances at the site of an arterial stenosis. Calcified arterial walls can also give rise to vibrations. The site of maximum bruit does not necessarily 
correspond to the site of the wibrations. The vibrations can be transported, attenuated or probably increased through the tissues. They can also be propagated from the heart through the arterial tree. Bearing this in mind, it is obvious that the usefulness of the detection of bruits wilm be of limited importance in the diagnosis of stenoses. In table II13 the femoral bruit is compared with the results of iliac Doppler examinations. The differentiation berween + and ++ is subjective $(+$ stands for a weak sound; ++ for a clear sound ). In the groups with clear and weak bruits there is an almost ewen number of Doppler recordings in the normal and the pathological group.

Table 11-13: Femaral artery bruits in the Doppler clastes I and W, and in the classes III through VI: the Doppler signals being recorded in the iliac ariery. $(0=$ no bruit; $+=$ weak bruit: $++=$ clear bruit)

\begin{tabular}{|lcccc|}
\hline \multicolumn{5}{c}{ femoral bruit } \\
& & \\
I.II & 0 & + & ++ & total \\
\cline { 2 - 5 } III.IV-V-VI & 99 & 21 & 12 & 132 \\
& 40 & 18 & 10 & 68 \\
\cline { 2 - 5 } & 139 & 39 & 22 & 200 \\
\hline
\end{tabular}

In table II-14 the results of the Doppler recordings $\mathrm{s}_{n}$ as performed in the femoral arteries, are compared with femoral artery bruits. Of the 61 limbs, showing a weak or clear bruit, there are 36 limbs with a normal femoral Doppler audiospectrum.

Table 11-14: Femoral artery bruits in the Doppler classes I and II, and in the classes III through IV; the Doppler signals being recorded in the femoral artery. $(0=$ no bruit; $+=$ weak bruit; $++=$ clear bruic)

\begin{tabular}{|c|c|c|c|c|}
\hline \multicolumn{5}{|c|}{ lemoral bruit } \\
\hline \multirow{4}{*}{$\begin{array}{l}\text { I-HI } \\
\text { III-IV-V-VII }\end{array}$} & 0 & + & ++ & total \\
\hline & 101 & 27 & 9 & 137 \\
\hline & 37 & 12 & 13 & 62 \\
\hline & 138 & 39 & 22 & 199 \\
\hline
\end{tabular}

In figure II-32 the mean $\%$ diameter reduction is shown with each femoral artery bruit group. There is no statistically significant difference between the groups. There is no correlation between femoral bruits and the degree of aortoiliac stenoses seen in the arteriogram. 


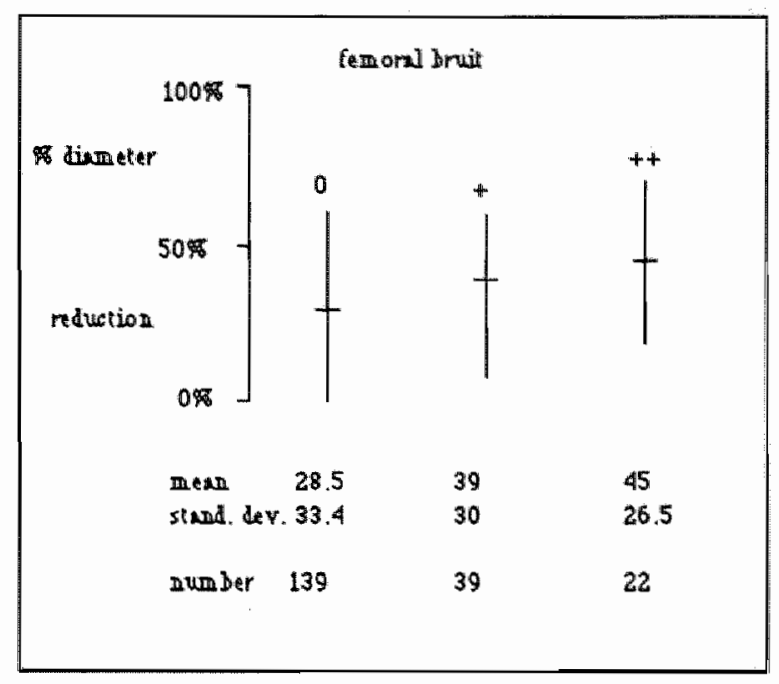

Fig. II-32: Mean $\%$ diameter reductions and stamdard deviatioms in the different femoral artery bruit groups $0=$ no bruit $;+=$ weak bruit ${ }^{+}+=$clear bruit $)$.

In figure II-33 and figure II-34 the mean pressure drop in the different bruit groups is shown at rest and during ractive hyperemia, respectively. There is no statistical difference between the groups.

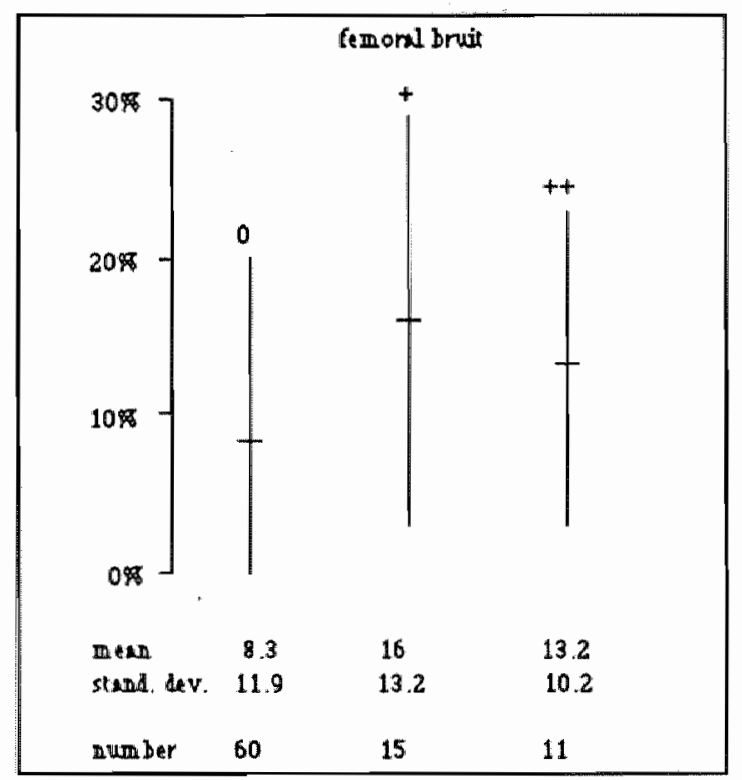

Fig. II-33: Mean \% pressure drops and standard deviations at rest in the different femoral artery brwit groups. $\left(0=\right.$ no bruit; $+=$ weak bruit ${ }^{*}+=$ clear bruit $)$. 


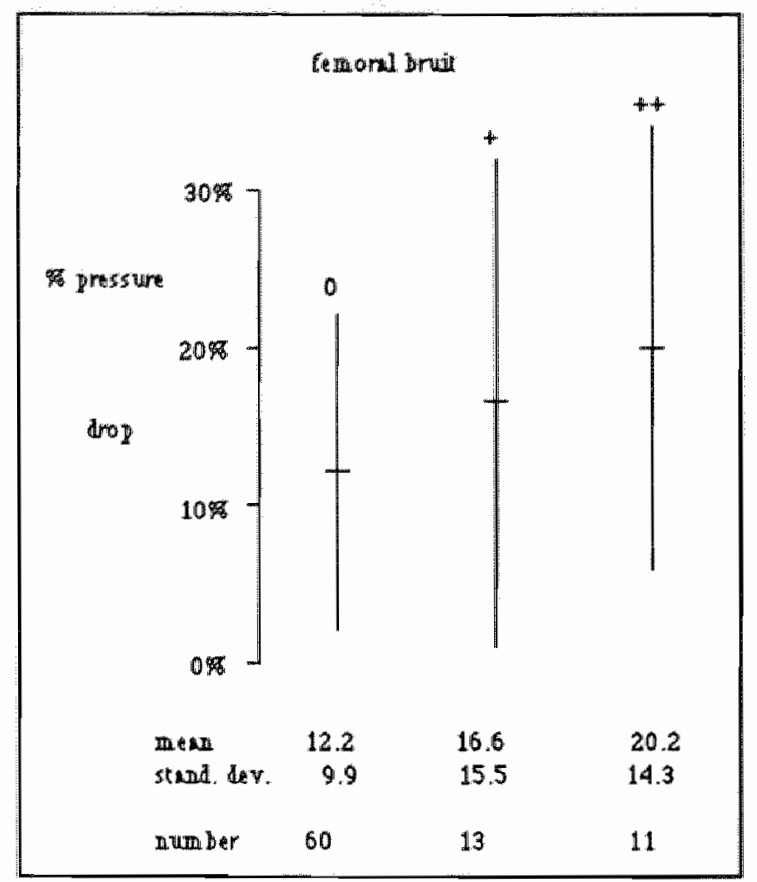

Fig. 11-34: Mean \% pressure drops and standard dewations during reacive hyperemia in the different femaral artery bruit groups. $(0=$ bruit absent $+=$ weak bruit $++=$ clear bruit $)$.

IX-4 Evaluation of parameters derived from the Doppler audiospectrum

IX-4-1 Reversed wave:

As mentioned before. the rewersed wave can be present in diseased arteries. The reversed wave is not only a result of a reflection from the periphery, but allso of the compliance of the vessel wall. Besides, under normal circumstances, reversed flow is seen at bifurcations on the side opposite to the flow divider. In table II-15 the reversed wave is compared with the degree of aortoiliac stenosis, as measured on the arteriogram. With increasing \% diameter reduction more spectra are seen without a reversed wave. 


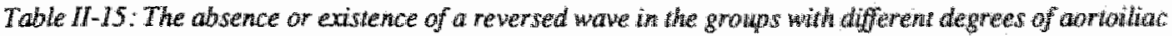
stenosis, as assessed in the arteriogram, the Doppler recordings being wade in the thac artery.

\begin{tabular}{|lrrrrrrrrr|}
\hline \multirow{8}{*}{ reversed wave } & $0-9$ & $10-39$ & $40-49$ & $50-59$ & $60-74$ & $75-94$ & $95-100$ & total \\
\cline { 2 - 9 } absent & 9 & 9 & 8 & 9 & 8 & 18 & 8 & 69 \\
existent & 61 & 41 & 11 & 4 & 3 & 2 & 0 & 122 \\
\cline { 2 - 9 } & 70 & 50 & 19 & 13 & 11 & 20 & 8 & 191 \\
\hline
\end{tabular}

From the R.O.C. curve shown in figure $\Pi-35$ the $\%$ diameter reduction, giving the best sensitiviy/specificity results for the reversed flow as parameter for important flow disturbances, can be determined.

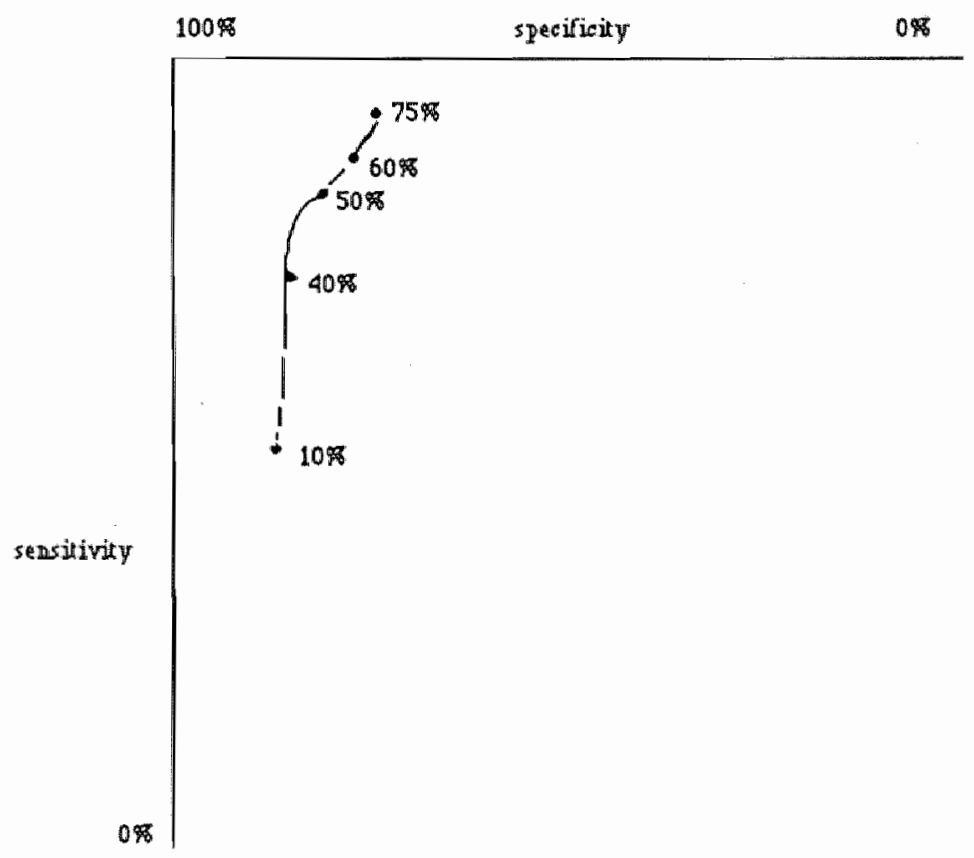

Fig. I-35: R.O.C. curve comparing the \% diameter reduction, as assessed in the arteriogram, and the absence or presence of reversed flow. 
At a cul-of point of $50 \%$ diameter reduction we found sensitivity of $83 \%$ and a specificity of $81 \%$. At a cut off point of $40 \%$ diameter reduction the sensitivity dropped to $72 \%$ with a specificity of $85 \%$. From these data it may be concluded that the absence of a reversed wave increases the chance of having an important aontoiliac stenosis.

\section{IX-4-2 Systolic peak}

The systolic peak is the peak frequency averaged over 15 consecutive beats. The systolic peak frequencies in the various Doppler spectrum classes are depicted in figure II36; the Doppler spectra were recorded in the iliac artery. Class IV and class V are significantly different from each other $(p<0.01)$ and from the other Doppler classes.

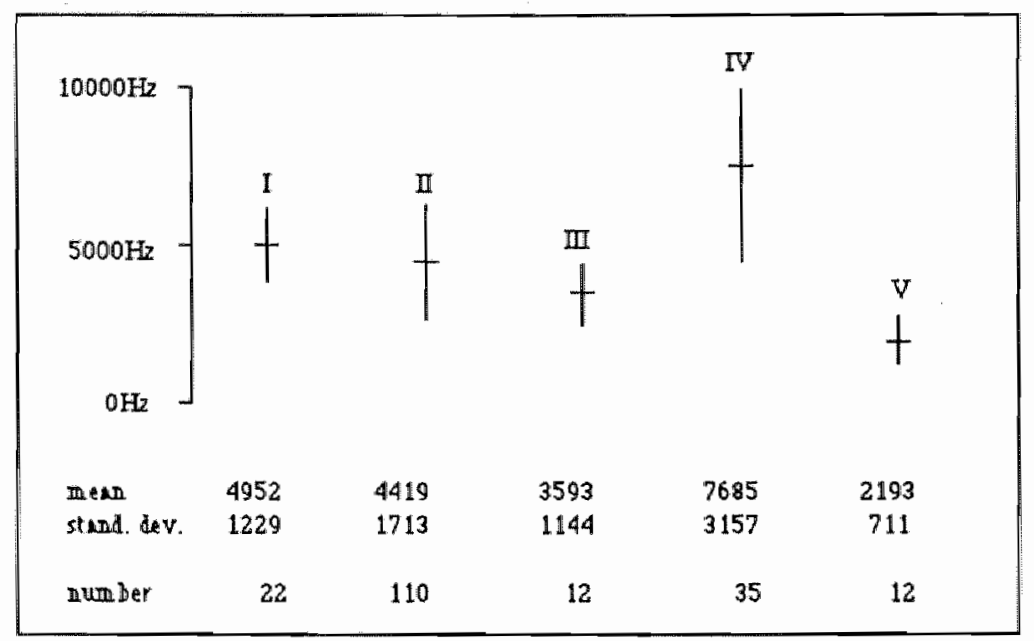

Fig. I-36: Mean systolic peak frequencies, as averaged over 15 consecutive beats, and standard dewiations in the different Doppler audiospecornen chasses. The Doppler signals being recorded in the iliac artery. 


\section{GENERAB DISUSSION}

The reason for performing this study was to develop a useful, non-invasive, easyto-perform and accurate method of investigating the state of the aortoiliac pathway. Especially with patients having multilevel diseases it is important for the surgeon to have a method available describing the hemodynamic or functional consequences of an aortoiliac stenosis, supplementary to the image of the arterial tree as obtained by arteriography.

Therefore, it was the aim of the present study to imvestigate whether with the use of continuous wave (CW) Doppler signals and using spectrum analysis of these signals, as recorded transcutaneously through the abdomen, aortoiliac lesions could be diagnosed accurately.

A prospective study was conducted using multiple criteria of the Doppler audiospectrum to distinguish different Doppler classes. The criteria used in the different classes are based upon the systolic peak, the upslope, the reversed wave and the window percentage of the Doppler spectrum. The window percentage is defined as the average area below the lower bandwidth divided by the average area below the upper bandwidth. The five different Doppler classes are described in table II- 2 and an example of each class is shown in the figures II-2 through II-6.

The results, as obtained in the iliac arteries, were compared with those obtained in the femoral arteries, because more accurate results could be expected when recording the signals close to the site of the possible lesion than more distally, as for instance in the femoral artery. The recording of signals in the femoral arteries, however, is easier, which is an advantage in clinical use. These same Doppler classes were used in both the iliac and the femoral arteries.

In order to obtain information about the accuracy of the Doppler method, as described in this thesis, the results obtained were compared with those obtained by the arteriogram and by pressure measurements. Arteriography was performed in a biplane view. The pressure measurements were made at rest and during reactive hyperemia. Furthermore, the results of the pressure measurements were compared with those obtained at arteriography to objectify their value.

Results of Doppler recordings.

The findings, as presented in table II -4 and in the figures II-9, II-10 and II 11 , 
indicate that the Doppler test fails when signals are recorded in the femoral artery. In this siruation the sensintwity of the Doppler test to detect an aontoiliac stenosis of $\geq 50 \%$ didmeter reduction is $70 \%$. The specificity to recognise a normal aortoiliac pathway or a stenosis with less than $50 \%$ diameter reduction is $85 \%$. The diagnostic accuracy of the test is $80 \%$.

Quite different results are obtained when the signals are recorded in the liac arteries, as shown in table II-5 and the figures II-14, II-15 and II-16. The sensitivity in detecting aortoiliac stenoses with $50 \%$ diameter reduction or more is $90 \%$. The specificity in detecting normal arteries or arteries with less than $50 \%$ diameter reduction is $90 \%$. The diagnostic accuracy of this test performed in the iliac arteries is $90 \%$.

As mentioned in chapter $\mathrm{XX}-2-2,6$ out of the 14 false positive results show an artoillic stenosis of more than $40 \%$ on the arteriogram. In those cases the Doppler test indicated the $40 \%$ stenosis. The diagnostic accuracy of the Doppler test in detecting aortoiliac: lesions with a diameter reduction of $40 \%$ or more is $86 \%$. Those figures are quite comparable with the results described in the literature summarized in table III-1. The results of screening lesions with a diameter reduction of $\geq 40 \%$ compare favourably with those obtained in some of the studies presented in the literature detecting stenoses with a diameter reduction of $\geq 50 \%$ diameter reduction.

Table II-1. Comparison of differem mon-invasive methods to detect aortoiliac stenosis with a diameter reduction of $\geq 50 \%$.

\begin{tabular}{|c|c|c|c|c|c|c|c|c|}
\hline & $\begin{array}{l}\text { Laplace } \\
\text { transform. }\end{array}$ & $\begin{array}{l}\text { Height } \\
\text { width }\end{array}$ & $\begin{array}{l}\text { Pulsatility } \\
\text { index }\end{array}$ & $\begin{array}{l}\text { Power } \\
\text { frequency }\end{array}$ & pullse & Max neverse & visual & this study \\
\hline sensilivily: & $85 \%$ & $93 \%$ & $87 \%$ & $93 \%$ & $89 \%$ & $84 \%$ & $87 \%$ & $90 \%$ \\
\hline spociflicily: & $84 \%$ & $88 \%$ & $96 \%$ & $92 \%$ & $88 \%$ & $86 \%$ & $88 \%$ & $90 \%$ \\
\hline * pred. value: & - & $93 \%$ & $98 \%$ & $92 \%$ & - & - & ^ & $80 \%$ \\
\hline prod. value: & - & $88 \%$ & $80 \%$ & 879 & - & 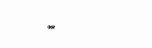 & $94 \%$ & $95 \%$ \\
\hline nCondacy. & . & $91 \%$ & $90 \%$ & $92 \%$ & $88 \%$ & $85 \%$ & * & $90 \%$ \\
\hline
\end{tabular}

Laplace transform (Baird 1980); Height width index (Johnston 1984); Pulsatility index (Johnston 1983); Power frequency spectrum analysis (Harward 1987); pulse: femoral pulse combined with thigh pressure index (Kitstat 1982); Max rewerse : maximal rowersed wave combined with upslope time (Kitslaar 1982); visual interpretation (Walton 1984).

The Laplace transform is a third order mathematical model. It combines parameters such as the distal impedance, the elasticity of the vessel wall and the proximal arterial lumen size. The maximum velocity-time waveform is used in Laplace transform analysis. The other parameters derived from the waveform are disregarded. Computer analysis of 
the signal is necessary to calculate the Laplace transfom. The correlation of Laplace transform with the minimum iliac diameter un combination with occlusion of the superficial femoral leads to an unsatisfactorily low comrelation coefficient $(r=-73)$. Although the obtained results are acceptable, but certainly not better than other methods, this approach is too complicated to be used as a routine procedure for diagnosing aortoiliac lesions in the clinic.

The pulsatility index is now available in most CW Doppler systems with spectrum analysis. The height width index is derived from the pulsatility index. Both parameters have the same diagnostic accuracy, comparable to the method described in this study. However, the presence of femoropopliteal occlusive diseases significantly reduces the accuracy of pulsatility index and height width index.

In power frequency spectrum analysis the power or amplitude of a recorded signal is presented as a function of frequency. Therefore, conversion of the signals is necessary. The method is too complicated to use by way of routine in the clinic. The obtained results, however, are independent of the presence of femoropopliteal lesions.

The femoral pulse combined with the thigh pressure index, as proposed by Kitslaar, is fairly comparable with other methods and has the advantage to be the cheapest. In fact it is a clinical parameter. Therefore, the results obtained are examinator -dependent and the question of reproductibility is unanswered. Since the different Doppler classes described in this thesis are well defined, the reproductibility is expected to be better than any clinical parameter.

The method of visual interpretation, as published by Walton in 1984 after the results of our study were available, is quite comparable to the one described in this study. In a group of 83 patients he made a distinction between four Doppler patterns: I: the primary wave is well defined with rapid rise and decay phases; II: there is an increased amplitude of low frequency signalls which results in filling in of the window; III: a well defined spectral broadening - multiple transient high frequency spikes are observed on the waveform in both forward and reversed flow direction; IV: a damped waveform with absent reversed flow. Comparing the results of this method with the results of arteriography, in which a $50 \%$ diameter reduction was considered to be a severe stenosis, the sensitivity is $87 \%$ and the the specificity $88 \%$. In the less than $50 \%$ stenosis group his Doppler technique underestimates the extent of disease.

The method described in the present study is able to diagnose rather accurately lesions with minor degree of diameter reduction i.e. between $40 \%$ and $50 \%$. This was observed when describing the false positive results. The method enables us to screen the iliac artery as proximally as possible, especially in non-obese patients. The lesions with at $40 \%$ diameter reduction are recorded directly over the stenosis. 
Considering our results and comparing them with the results of the methods described in the literature, it can be concluded that the method described in this study a good alternative in detecting non-invasively aortoiliac stenoses with diameter reduction of $50 \%$ on the arteriogram. Furthermore, the method is able to detect stenoses with a smaller diameter reduction when the aortoiliac artery can be screened directly.

If we compare these results with those obtained when examinating the femoral arteries, then the sensitivity declines to $70 \%$, the specificity to $85 \%$, and the diagnostic accuracy to $80 \%$. Therefore, it can be concluded that the method for screening the iliac arteries, as presented in this thesis, is more accurate when the signals are recorded through the abdomen than when they are recorded on the femoral arteries.

Results of pressure measurements.

Intra-arterial pressure measurements are believed to be a new gold standard in detecting stenoses in arteries (Brener 1974, Brewster 1978, 1982, Flanigan 1982, Verhagen 1985). As described in chapter IV-2 there is no agreement about the exact definition of pressure drop along the arterial tree at rest or during reactive hyperemia with specific arterial namowing. There is no "critical" stenosis (Flanigan 1977). More than half of the studies describe absolute pressure values instead of the more reliable relative values. The relative pressure at rest is the percentage of pressure drop found when measuring the intra - arterial pressure proximal of and distally to a stenosis. The relative pressure during reactive hyperemia is the percentage pressure drop measured distal to the stenosis before and after a reactive hyperemia test is performed. In absolute pressures there is an influence of the systemic blood pressure of the patient, in relative pressures this factor is excluded.

It is not easy and probably impossible to measure or to objectify the real value of pressure measurements. Verhagen used the clinical outcome as standard, when comparing the results obtained with pressure measurements. We did not use clinical outcome in this study because the parameter is subjective or can only partly be objectified by arm/ankle pressure indices. We compared the pressure measurements with the results obtained on biplane arteriograms (chapter IX-2-3-1). In figure II-17, II-18 and II-19 the mean pressure drop with standard deviation at rest and during reactive hyperemia is shown. The number of measurements is too small to draw definite conclusions, but they indicate that in lesions with a diameter reduction of $50 \%$ and more there is a significant difference in mean percentage pressure drop at rest and during reactive hyperemia, as compared with lesions with less than $50 \%$ diameter reduction.

Arteriography and pressure measurements are not well correlated as could be expected 
theoretically. In the description of arteriography no attention is made towards the length or the morphological presence of the stenosis. However the pressure drop along a stenosis is related to the lenght of this stenosis (the boundary layer loss fig. $[-6$ ) in a steady flow pattem. Classification of stenoses taking into account length and morphological presence together with diameter reduction is however not usefull.

The Doppler results, as obtained in this study are compared with the pressure measurements in chapter IX-2-3-2. Using R.O.C. curves (figure II-22 and figure II-24) the best sensitivity/specificity results were found with a pressure drop at rest of more than $12 \%$ and during reactive hyperemia of more than $20 \%$. The diagnostic accuracy of the Doppler test is $81 \%$ in detecting aortoiliac lesions with a pressure drop at rest of more than $12 \%$. The diagnostic accuracy of the Doppler test is $86 \%$ in detecting arortolliac lesions with a pressure drop during reactive hyperemia of more than $20 \%$. When both pressure tests are combined ( $>12 \%$ and $>20 \%$ ), the diagnostic accuracy is $83 \%$. In 10 out of the 12 false positive tests, when the combined pressure test was used as standard, the Doppler test is in accordance with the results of the arteriogram. There were two false negative tests. These findings indicate that the pressure test is less accurate than the Doppler test and arteriography in diagnosing functional lesions in the aorto-iliac pathway.

A complicating factor in pressure measurements is that the percentage pressure drop across a stenosis does not only depend on the degree of artery narrowing, but also on the state of the arterial tree distal to the site of pressure measurements. If, for example, the superficial femoral artery is occluded, the pressure distal to the aortoiliac stenosis is higher than can be expected from the degree of narrowing leading to erroneous conclusions (see figure II-25).

It can be concluded that, even when there is a gradual increase in percentage pressure drop at rest and during reactive hyperemia with the severeness of the disease as depicted by the Doppler test (figure II-20), the pressure measurements are a less reliable indicator of the severeness of the disease. They do not provide additional information about the aortoiliac pathway, as compared with the Doppler test alone. The value of pressure measurements is at least doubtful in the presence of combined important inflow and outflow stenoses.

Clinical parameters.

Patients complaining of thigh claudication have a significant chance of showing important aortoiliac lesions on the arteriogram. The mean percentage diameter reduction found on the arteriogram with patients having thigh claudication is $62,8 \%$ and differs significantly from the reduction found in patients without thigh claudication (mean percentage diameter reduction 23\%). The symptom 
thigh claudication, however, is not necessarily found in the presence of aortoiliac stenoses. There are as many limbs with and without thigh claudication in the patient group with important lesions, as diagnosed with the Doppler method.

Interpretation of the fernoral pulse is extremely subjective and investigatordependent. The reproductibility of this parameter is minimal (K. A. Meyers 1987). When pertormed by the same investigator a difference is found between normal and weak pulsations. With a weak pulsation the mean percentage aortoiliac diameter reduction is $43 \%$. A mean percentage reduction of 21 is found with a normall pulse.

Detection of femoral bruits has no value as clinical parameter in aortoiliac lesions.

When a patient is presented with multilevel occlusive disease nowadays, what are the measures to be made to accurately diagnose the importance of the disease so that vascular reconstructions lead to optimal results?

Clinical exarnination and history of the patient are the first parameters. Diminished pulsations and possibly thigh claudication are of special interest. Secondly the Doppler examinations provide additional information. The ankle/arm pressure index measures the existence of vascular pathology (Buth 1978). The Doppler method described in this study and performed in the iliac arteries gives an accuracy of $90 \%$ to diagnose important aortoiliac lesions. Both non-invasive methods are easy to perform and to interpretate, and are cheap. If these examinations indicate that vascular pathology is present and reconstructive surgery will be necessary arteriography is performed. In view of this study and using the described Doppler method, there is no place for performing invasive pressure tests.

With the introduction of Duplex scanning, which progressively replaces the other non - invasive tests in carotid artery stenosis, there was some hope that this method would open new horizons concerning the diagnosis of aortoiliac lesions. Kohler (1987) examined 393 arterial segments (from the distal part of the artat to the popliteal artery). Using three ultrasonic criteria, namely (1) > $100 \%$ increase in peak systolic velocity, (2) loss of reversed flow in diastole and (3) detection of spectral broadening, the sensitivity was $89 \%$ and the specificity $90 \%$ for detecting aortoiliac stenosis with a diameter reduction of $>50 \%$. Langsfeld (1988) detected in 166 aortoiliac segments, derived from 29 patients, using Duplex scanning with a pulsed Doppler probe, severe aonoiliac diseases ( $>50 \%$ diameter reduction ) with a sensitivity of $82 \%$ and a specificity of $93 \%$. The results obtained are similar to those obtained in the present study in which less expensive equipment is necessary. 
To be able to non - invasively diagnose functional lesions and lesions with a smaller degree of narrowing in the aortoiliac pathway, more accurate rew routes have to be explored. One possibility is to directly image the vascular tree with B-mode imagers with possibility of tissue characterization. Another possibility is to visualize arteries with the use of magnetic resonance techniques. An interesting new approach is the detection of locally diminished arterial wall distensibility (Reneman et $\mathrm{al}_{*}, 1.988$ ), which is shown to be an important parameter in the diagnosis of minor canotid artery lesions (Van Merode et al., in press). 
The aim of the present study was to investigate whether

- spectral analysis of the continuous wave (CW) Doppler signal, as recorded in the iliac arteries, is an accurate method for diagnosing hemodynamically siginificant stenoses in the aortoiliac pathway;

- there is a difference between recordings made in the femoral and the illiac arteries, as far as the diagnostic accuracy of these stenoses is concerned;

- pressure measurements in the aortoiliac pathway give additional information.

To this purpose, CW Doppler signals were recorded in the femoral and iliac arteries, the signals being processed with audiospectrum analysis. The iliac arteries were screened transcutaneously through the abdomen. The degree of stenoses in the artoiliac pathway was assessed with the use of five different audiospectrum categories, distinguished on the basis of parameters such as the maximum systolic frequency, the maximum reversed wave, the upslope during systole and the degree of spectral broadening expressed as window percentage. The accuracy of this approach was evaluated in a prospective study with one hundred patients. Biplane arteriography was used as the gold standard. Pressure measurements were performed at rest and during reactive hyperemia through the Seldinger catheter used for arteriography.

In chapter I a brief summary is given of atherosclerosis of the lower extremities. with emphasis on the multifactorial etiology of the disease. The site of preference of atherosclerosis in the lower extremities is discussed in relation to differences between diabetic and non-diabetic patients.

In chapter II the dynamics of blood flow are discussed, paying special attention to pressure, flow velocity profilles and the impact of collateral circulation. Pressure is dependent on flow and peripheral resistance. There is a pressure drop along the arterial tree due to gravity, flow acceleration, viscous losses according to Poiseuille, convective acceleration losses according to Bernoulli and boundary layer losses. Under nomal circumstances the velocity profile, defined as the velocity distribution over the crosssectional area of the blood vessel, is symmetrical. It changes its shape during each cardiac cycle from flat to a more parabolic shape. Disturbances in the velocity profile are indicative of the presence of atherosclerotic lesions and, hence, can be used as a diagnositic criterion. Information about these flow disturbances can be obtained with the use of CW or pulsed Doppler systems. The impact of the collateral circulation, although it is difficult to measure, is important as far as the level of peripheral resistance is 
concerned.

In chapter III the Doppler technique is discussed, especially its application to the aortofemoral tree. The Doppler signal is the difference in frequency between emitted and back-scattered sound. The Doppler signal can be processed with the use of audiospectrum analysis. The audiogpectrum represents the distribution of red blood cell velocities in the sample volume during the cardiac cycle. Audiospectrum analysis of the Doppler signal gives nore information than the anallog tracings originally used. The sound beam can be enitted continuously (CW Doppler) or intermittently (Pulsed Doppler). CW Doppler instruments are less expensive and easier to operate. Therefore, the present study was. performed with these devices. The parameters, as derived from the audiospectrum and most commonly used, are discussed including their advantages and disadvantages.

In chapter IV biplane arteriography and pressure measurements during arteriography are discussed. Arteriographic examinations are morphological in nature, while pressure measurements are supposed to provide hemodynamic information. Pressure measurements during reactive hyperemia could give valuable information because some arterial lesions only induce hemodynamic changes during increases in blood flow.

In chapter $V$ the patient group under investigation is discussed. Twenty-one percent of the patients were women. Most of the patients examined were between 50 and 70 years of age. Thirty-four percent of our patients had or were having complaints of angina pectoris. This relatively high number is probably caused by the fact that we have been dealing with a selected group of patients because the hospital is running a cardiosurgical unit with a regional function.

In chapter VI the methods of examination are discussed. With the use of CW Doppler combined with audiospectrum frequency analysis (Angioscan (B)), five different patterns of the spectrum were used to estimate the severeness of the disease in the aortoilic pathway, screening either the iliac artery or the femoral artery. The clinical state of the patient was recorded after having performed the Doppler examinations. At this moment the pulse of the femoral arteries was judged and the presence of femoral bruits, if any "recorded.

In chapter VII the details of the equipment used for Doppler examinations, arteriography and pressure measurements are discussed. Biplane arteriography and the pressure measurements were performed by the radiologist. The results of the Doppler test were compstred with biplane arteriography in 200 legs, and with pressure measurements in 86 patients both in a prospective blind study. Pressure measurements were performed on the most severely diseased side.

Statistical analysis was performed by means of the sensitivity/specificity decision 
matrix, the receiver - operating - characteristic (R.O.C) curve and appropriate statistical tests to evaluate the significance of the differences observed. These aspects are described in Chapter VIII.

In chapter LX a detailed analysis of the results, as obtained in this study, is described. When screening the iliac arteries and comparing the results with the percentage diameter reduction on the arteriogram, the Doppler technique, as proposed in this study, gives a sensitivity, specificity and diagnostic accuracy of $90 \%$ in the diagnosis of lesions with a degree of narrowing of $\geq 50 \%$. In 10 out of the 14 false positive results an aortoiliac stenosis of $\geq 30 \%$ diameter reduction was found, and in 6 out of them even a reduction of $\geq 40 \%$. These degrees of stenoses were detected by the Doppler method, since they gave rise to flow velocity disturbances.

The diagnostic accuracy of the test in detecting stenoses with a diameter reduction of $\geq 40 \%$ is $86 \%$ when the Doppler signals are recorded in the iliac arteries. A value comparable with the results obtained with various tests described in the literature, when detecting lesions with a diameter reduction of $50 \%$ or more.

The diagnostic accuracy of the test in detecting stenoses with a diameter reduction of $\geq 50 \%$ is only $80 \%$ when the Doppler signals are recorded in the femoral arteries.

When comparing arteriography with the pressure measurements, a statistically significant percentage pressure drop was only seen in lesions with $\geq 70 \%$ diameter reduction at rest and during reactive hyperemia.

When the mean percentage pressure drop at rest and during reactive hyperemia for each different Doppler class is compared, then a significant difference is found between Doppler class I and II on the one hand and Doppler classes III to V on the other.

Pressure measurements at rest and during reactive hyperemia can be combined to one diagnostic test. Using the R.O.C. differentiation the test is considered as indicative of an important lesion if the pressure drop is $\geq 12 \%$ at rest and $\geq 20 \%$ during reactive hyperemia. Comparing the results of the iliac Doppler examinations when both test are combined results in a sensitivity of $87 \%$, a specificity of $81 \%$ and a diagnostic accuracy of $83 \%$. However, in 10 out of the 12 false positive cases, the results of the Doppler examinations were in accordance with the results of the arteriography. Furthermore, it was found that in cases with an important inflow and outflow stenosis, the pressure tests were unable to accurately diagnose the important inflow stenosis.

The use of the existence or absence of the reversed wave as an individual parameter provided a sensitivity of $83 \%$ and a specificity of $81 \%$ in screening iliac arteries with a diameter reduction of $50 \%$ or more.

Evaluation of the clinical parameters revealed that thigh claudication is a significant sign of an important aortoiliac stenosis. 
The following conclusions can be made:

1. The Doppler method described in this study is a good alternative in detecting noninvasively aortoiliac stenoses with a diameter reduction of $50 \%$ or more in the anteriogram. Furthermore, the method is able to detect stenoses with smaller diameter reduction when the aortoiliac arieries are screened directly.

2. The method for screening the aortoiliac pathway, as presented in this thesis, is more accurate when the signals are recorded in the iliac arteries than when they are recorded in the femoral anteries.

3. Pressure measurements are a less reliable indicator of the severeness of the disease.

They do not provide additional information about the aortoiliac pathway, as compared to the Doppler test alone. The value of pressure measurements is at least doubtful in the presence of combined important inflow and outflow stenoses.

4. Patients complaining about thigh claudication have a significant chance of showing important aortoiliac lesions in the arteriogram. 


\section{SAMENVATTING}

De opzet van dit onderzoek was na te gaan of

- spectraalanalyse van het Continuous Wave (CW) Doppler signaal, zoals opgenomen in de a. iliaca, een betrouwbare, niet-invasieve methode is om laesies in het aortoiliacale traject op te sporen;

- er een duidelijk verschil bestaat in het resultaat van het Doppler onderzoek wanneer het signaal geregistreerd wordt in de a. iliaca of in de a. femoralis;

- intra-arteriele drukmetingen additionele informatie verschaffen over de toestand van het aortoiliacale traject.

CW Doppler onderzoek van de a. fernoralis en de a. iliaca werd verricht met behulp van spectraalanalyse. De signalen in de a. iliaca werden transabdominaal geregistreerd. De mate van vernauwing in het aortoiliacale traject werd bepaald met behulp van vijf verschillende audiospectrum categorieën die onderscheiden werden met behulp van de maximale systolische frequentie, de maximale negatieve frequentie, de stijgsnelheid tijdens systole en de mate van invulling van het venster in het spectrum. De nauwkeurigheid van deze methode werd geëvalueerd in een prospectieve studie bij honderd patienten. Arteriografie in twee richtingen werd gebruikt als gouden standaard. Intra-arteriële drukmetingen werden verricht in rust en tijdens reactieve hyperemie met behulp van de Seldinger catheter.

In hoofdstuk I wordt een samenvating gegeven van de huidige hypothesen omtrent de oorzaken van atherosclerose. Het voorkomen van deze ziekte in het aortoiliacale traject en de onderste ledematen wordt besproken in relatie tot de verschillen waargenomen tussen diabetici en andere patienten.

In hoofdstuk II wordt een beschrijving gegeven van arteriële circulatie, waarbij speciale aandacht besteed wordt aan bloeddruk, het snelheidsprofiel en de invloed van de collaterale circulatie. De bloeddruk is afhankelijk van de bloedstroomsterkte en de perifere weerstand. Het bloeddrukverval in het arteriële systeem wordt veroorzaakt door de zwaartekracht, de acceleratie van' de bloedstroom tijdens de pulsatie, de inertie van de bloedmassa, het drukverlies door wrijving volgens Poisseuille en het drukverlies door bloedstroomversnelling volgens Bernoulli wanneer het bloed door een nauwer gedeelte stroomt. Onder normale omstandigheden is het snelheidsprofiel, gedefinieerd als de snelheidsverdeling over de dwarsdoorsnede van het bloedvat, symmetrisch. Het snelheidsprofiel variëert tijdens de hartslag van vlak tot meer parabolisch. Verstoringen in 
de vorm van het snelleidsprofiel zijn een aanwijzing voor bloedstroomweranderingen ten gewolge vin atherosclerotische afwijkingen. Informatie over deze stroomwerstoringen kan verkregen worden met behulp van Doppler systemen.

De inwlod van de collaterale circulatie, die in belangrijke mate de perifere weerstand bepald, is moeljk te berekenen.

Hoofdstuk II handelt over het Doppler fenomeen, met name de toepassing hiervan in het aortoiliacale traject. De Doppler shift is het werschil tussen de vitgezonden en ontwangen frequentie. Het spectrum wan het Dopplersignaal is een weergave van de smelheidsverdeling van de rode bloedcellen rijdens de hartcyclus. Het audiospectrum bevat belangrijk meer informatie dan het analoge signaal, zoals in het verleden gebruikt werd. Het audiospectrun geeft een beeld van de verschillende strooms nelheidsvectoren, het analoge signaal is een benadering van het gemiddelde. Het ultrageluid kan continu (CW Doppler) of intermitterend (Pulsed Doppler) uitgezonden worden. CW Doppler systemen zijn goedkoper in aanschaf en eenvoudiger te bedienen. Deze studie werd verricht met behulp van een CW Doppler systeem gecombineerd met audiospectraal analyse Een literatuuroverzicht van de verschillende parameters, zoals afgeleid uit het audiospectrum, met de woor-en nadelen worden besproken.

In hoofdstuk IV worden de arteriografie en de drukmetingen besproken. Arteriografie is beeldvorming en geeft dus statische informatie. Daarentegen veronderstelt men dat drukmetingen dynamische informatie verschaffen over de bloedstroom. Tijdens inspanningstesten, in deze studie gesimuleerd door reactieve hyperemie uit te lokken, kan een drukverval gedetecteerd worden ondat dan het bloedwolume dat per tijdseenheid verplatatst wordt, groter is.

In hoofdstuk $V$ wordt de onderzochte patientengroep beschreven. Een op vijf patienten was vrouwelijk. De meeste patienten wamen tussen 50 en 70 jaar oud. Een op drie patienten had angina pectoris of was vroeger hiervoor behandeld. Dit hoge percentage is wellicht het gevolg van het feit dat een gedeelte van de patienten werd verwezen via de cardiochirurgische dienst van het ziekenhuis met een abnormale selectie op cardiaal gebied als gevolg.

In hoofstuk. VI wordt de opstelling voor het Doppler onderzoek gepresenteerd. Er werd gebruik gemaakt van een CW Doppler systeem met audiospectraal analyse (Angioscan(B). Vijf verschillende spectraal patronen werden onderscheiden en gebruikt om de emst van de afwijking in het aortoiliacaal traject vast te stellen. Na dit onderzoek werd de anamnese afgenomen en een klinisch onderzoek verricht met speciale aandacht voor de femoraal pulsaties en de mogelijke aanwezigheid van artriële genuisen.

In hoofdstuk VII wordt de apparatuur, die gebruikt werd voor het Doppler onderzok , de arteriografie en de drukmetingen voorgesteld. Arteriogrammen werden in 
twee richtingen gemaakt door de radioloog, die ook intra-arterielle drukmetingen verrichte bij 86 patienten. De resultaten van de Doppler test werden prospectief en blind vergeleken met de resultaten van de arteriografie en de drukmetingen.

Statistische beoordeling van de resultaten werd verricht met behulp van $R .0 . C$. curves, sensitiviteit en specificiteit berekeningen, en de Mann-Whitney test om de significante verschillen tussen groepen op te sporen. Deze aspecten zijn beschreven in hoofdstuk VIII.

Een gedetailleerde analyse van de resultaten wordt gegeven in hoofdstuk IX. Het Doppler onderzoek van de a. iliaca, zoals in deze studie beschreven, kan stenosen met een $50 \%$ diameter vernauwing of meer op het arteriogram op sporen met een sensitiviteit, een specificiteit en een diagnostische nauwkeurigheid van $90 \%$. Hierbij werden 14 vals positieve resultaten verkregen. In 10 van deze 14 gevallen werd een aortoiliacale stenose van $\geq 30 \%$ gevonden, en in 6 van deze gevallen zelfs een stenose van $\geq 40 \%$. Deze artoiliacale vernauwingen werden dus met de beschreven Doppler techniek gediagnostiseerd omdat deze aanleiding gaven tot storingen in het snelheidspatroon.

De beschreven Doppler test is in staat om laesies op te sporen die een stenose van 2 $40 \%$ op het arteriogram vertonen met een diagnostische nauwkeurigheid wan $86 \%$ wanneer het onderzoek wordt verricht ter hoogte van de a. iliaca. Dit is vergelijkbaar met sommige andere niet-invasieve methoden voor het opsporen van aortoiliacale vernauwingen met een diameter vernauwing van $50 \%$ of meer.

De resultaten van de Doppler test zijn ontmoedigend wanneer de Doppler signalen geregistreend werden in de a. femoralis. Dit was te verwachten ondat de methode nauwkeuriger is naarmate men de signalen dichter bij de laesie opneemt.

Wanneer men de resultaten van de arteriografie vergelijkt met drukmetingen in rust en na inspanning dan wordt slechts een statistisch significante drukdaling gevonden bij stenosen met een diameter vernauwing van $\geq 70 \%$.

Wanneer men het gemiddelde drukvervall in rust en tijdens reactieve hyperemie vergelijkt met de verschillende classificaties van het Doppler spectrum wordt een significant werschil gevonden tussen enerzijds klasse I en II en anderzijds klasse III, IV en $\mathrm{V}$.

Drukmetingen in rust en tijdens reactieve hyperaemie kunnen worden gecombineerd als een enkele diagnostische test voor het opsporen van laesies. Gebruik makende van R.O.C. differentiatie werd een laesie significant gevonden wanneer er een drukverval in rust was van $12 \%$ of meer en tijdens reactieve hyperaemie van $20 \%$ of meer. Met het Doppler onderzoek kunnen laesies, die een drukverval wan $\geq 12 \%$ en $\geq 20 \%$ induceren, opgespoord worden met een sensitiviteit van $87 \%$, een specificiteit van $81 \%$ en een 
diagnostische nawkeurigheid van $83 \%$. Er waren hierbij 12 vals positieve resultaten. Bij 10 van deze 12 gevallen was het Doppler onderzoek in overeenstemming met de resultaten wan de arteriografie. Bovendien werd bij de beoordeling van de resultaten vastgesteld dat de drukmetingen niet un staat zijn belangrijke inflow stenosen op te sporen, wanneer deze gepaard gaan met een duidelijke outflow stenose. De drukmetingen falen dus bil gecombincerde significante stenosen.

De asn- of afwezigheid wan de omgekeerde golf als individuele parameter vertoonde een sensitiviteir van $83 \%$ en een specificiteit van $81 \%$ bij het opsporen van laesies met een diameter vernawwing op het arteriogram van $50 \%$ of meer.

Uit thet onderzok blijkt dat patienten met een duidelijke dij-claudicatio een statistisch significante kans hebben op een belangrijke aortoiliacale stenose.

De conclusies van het onderzoek zijn:

1. Het Doppler onderzoek zoals hier beschreven, is een goed en gelijkwarardig alternatief voor bestaande niet-invasieve methoden waarbij aortoiliacale laesies met een diameterreductie van $50 \%$ of meer op het arteriogram worden opgespoord. Bovendien is de methode in staat om laesies op te sporen met een geringere diametervernauwing wanneer de signalen opgenomen worden in de a. iliaca.

2. De methode is veel betrouwbarder wanneer de Doppler signalen opgenomen worden in de a. lliaca dan in de a. femoralis.

3. Drukmetingen, zoals verricht in dit onderzoek, zijn wan ondergeschikt belang bij het opsporen van aortoiliacale stenosen. Zij geven geen additionele informatie, in vergelijking met het Doppler onderzoek alleen. De drukmetingen leiden bovendien tot onbetrouwbare resultaten wanneer er gelijkertijd belangrijke inflow en outflow stenosen aanwezig zijn. 4. Patienten met dijwclaudicatio hebben een significante kans om een belangrijke aortoiliacale stenose te vertonen op het arteriogram. 


\section{REFERENCES}

\section{J.P. Archie, R.W. Feldtmann}

"Determination of the hemodynamic significance of iliac antery stenosis by noninvasive Doppler wltrasonography" Surgery, april 1982, pp 419-423

J.P. Archile, R.W. Feldtmann

"Intraoperative assessment of the hemodynamic significance of iliac and profunda femoris artery stenosis." Surgery, wol 90, nov 1981, pp 876-880

J.P. Archie

"Nondimensional normalized femoral Doppler waweform indices to predict the hemodynamic significance of iliac artery stenosis." Surgical Forum, vol 30, 1979, pp 191 193

A. Aukland, R.A. Hurlow

"Spectral analysis of Doppler ultrasound: its clinical application in lower limb ischaemia"

Br. J. Surg. voll 69, 1982, pp539-542

M.G.J. Arts, J.M.J.G. Roevros

"On the instantaneous measurement of blood flow by ulltrasonic means."

Med. \& Biol. Engng, vol 10, 1972, pp 23-34

J.M. van Baalen

"Noninwasive detection of lesions in the carotid artery bifurcation." thesis, Maastricht 1987

H. S. Badeer

"Elementary hemodynamic principles based on modified Bernoulli's equation."

The Physiologist, vol 28, nr.1, 1985, pp $41-46$

R.N. Baird, P. Feldman, J.T, Miles, P.M. Madras, J.F. Gurry

"Subsequent downstream repair after aortoiliac and aortofemoral bypass operations."

Surgery, vol 82, nr. 6, 1977. pp 785-793

R.N. Baird, D.R. Bird, P.C. Clifford, R.J. Lusby, R. Skidmore, J.P. Woodcock

"Upstream stenosis, its diagnosis by Doppler signals from the femoral artery"

Arch. Surg. vol 115, nov 1980, pp 1315-1322

A.R. Baker, D.H. Evans, D.R. Prytherch, P.R.F. Bell

"Hemodynamic assessment of the femoropopliteal segment: comparison of pressure and Doppler methods, using ROC curve analysis." Br. J. Surg.; vol 73, july 1986, 559-562

P. Balas, Th. Segditsas, D. Koutsopoulos.

"The value of the ultrasonic flowmeter in the diagnosis of arterial discases."

Angiology voll $21,1970, \mathrm{pp} 451-461$

H. Barcroft

"The mechanism of vasodilatation in the limbs during and after the arrest of the circulation."

Angiology, vol 23, nr.10, nov 1972, pp 595-599

R.W. Barnes

"Hemodynamics for the vascular surgeon" Arrch. Surg. woll 115, feb 1980, pp 216-223

R.W. Barnes, G.E. Bone, J.E. Reinertsen, E.E. Slaymaker, D.E. Hokanson, D.E. Strandness jr.

"Noninvasive Ultrasonic carotid angiography: prospective validation by contrast angiography."

Surgery vol 80,1976, pp 328-335

M. Barringer, G.V. Poole, A.C. Shireliffe, J.W. Mered ith, F. Hightower, G.W. PJonk:

"The diagnosis of aortoiliac disease, a moninvasiwe femoral cuff technique."

Ann. Surg., vol 197, febr. 1983, pp 204-209

P.J. Bendick, J.L. Glover

"Detection off subcritical stenoses by Doppler spectrum analysis."

Surg. vol 91, june 1982, nr. 6, pp 707-711.

P.J. Bendick, J.L. Glover, R.S. Dilley

"Transcutaneous detection of subcritical arterial stenoses by Doppler signal spectrum analysis."

J. Ultras. Med. voll 2, oct. 1983, pp 445-449

P.J.L.M. Bernink, A.A. Wouda 
"Meting wand de bloedsowlloop in de benen wan patienten met atherosclerosis obliterans, voor en na operalle "Ned. T. Goncesk vol 125, nr. 44, 1982, pp 1786-1792

E.F. Bermstein, T.H. Wizel, U.S. Stots, A. Fronek

"Thigh pressire artifacs with noninvasive techniques in an experimental model."

Surgery, woll 89 ni. 3, march 1981, pp 319.323

E. Betz.

"Experimental atheroselerosis" ediorial in Trendis in experimental atherosclerosis.

Intern. Angiology wall 6, nr. 1, 1987, pp 5-6

D.R. Dird, R. Skidmore, J.P. Woodcock

"The value of Doppler transfer function analysis in the diagnosis of aorioiliac occlusive arterial disease." in: Diagnosis and Monitoring in arterial surgery edt R.N. Bard and J.P. Woodcock, J. Wright Bristol 1980, pp 121-125

D.H. Blankenhorn

"Will atherona regress with dich and exercise?" Am. J. Surg. vol 141, june 1981, pp 644-645

H. Boecalon " M. Reggi, A. Lozes, C. Canal, J.M. Jausseran, R. Courbier, P. Puel, A. Enjalbert

"L' interet de l' analyse spectrale des frëquences par examen Doppler."

$J$. des Maladies valsculaires vol 6, $1981 \mathrm{nr} .1 \mathrm{pp} 55-59$.

R.A. Bomberger, C.K. Zarins, S. Glagov

"Subcritical anterial sienosis enhances distal atherosclerosis."

J. Surg. Rescarch wol 30, 1981, pp 205-212

M. Brandestini

"Topoflow - a digital full range Doppler welocity meter."

TEEE - Transactions on sonics and ultrasonics suppl. 25, 1987, pp 287-293

P.J. Breslau

"Ultrasonic Duplex scanning in the evaluation of carotid antery disease."

Marstricht, The Netherlands, 1981

B.J. Brener, J.K. Raines, R.C. Darling, W.G. Austen

"Measurement of systolic femoral arterial pressure during reactive hyperemia."

Circulation suppl. wol 49\&50, aug. 1974, pp II-259-267

D.C. Brewster "R.C. Darling

"Optimal methods of aortoiliac reconstruction" Surg. vol 84 dec. 1978, nr. 6, pp 739-747

D.C. Brewster, B.A. Perler, J.G. Robinson, R.C. Darling

"Aontofemoral graft for multilewel occlusive disease." Arch. Surg. vol 117 dec 1982, pp 1593-1600

D.C. Brewster, A.C. Waltman, P.J. O"Hara, R.C. Darling

"Femoral artery pressure measurement during aortography."

Circ. suppl. vol, $60 \mathrm{nr}$. 2, august 1979, pp I-120 -123

H. Bruins Slot

"Doppler studies in the fenoropopliteal pathway" thesis, Maastricht 1981

H. Bruins Slot, IL. Strijbosch, J.M. Greep

"Interobserver variatbitity in single-plane aorlography." Surgery wol. 90, 1981 pp 497

J. Buth

"Het vasculaire laboratorium" thesis Amsterdam $1978 \mathrm{eds}$ Bronder-Offset B.V.

W.B. Camplelli, R.N. Baird, S.E.A. Cole, R. Skidmore, J.P. Woodcock

"Physiological interprotation of Doppler shifi waveforms: the fernorodistal segment in combined disease."

Uliras. in Med. Biol. vol9 nr. 3, 1983, pp 265-269

W.B. Camplielll, R. Skidmore, R.N. Baird

"Variability and reprodlucibility of arterial Doppler waveforms."

Ultras. in Med. Biol, vol. $10 \mathrm{mr} .5,1984 \mathrm{pp} 601-606$

W.B. Campbell, S.E.A. Cole, R. Skidmore, R.W. Baird

"The clinician and the vascular laboratory in the diagnosis of aortoiliac stenosis."

Br. J. Surg. vol 71, 1984, pp 302-306

S.N. Carson, G. Hunter, H.N. Wong, P.A. Farrer

"Dynamic isotope aortoiliac assessment" Surg. vol 115, july 1980, pp 859-862

W. Castaneda-Zunigg, L. Knight, A. Formanek, R. Moore, V. D'Souza, K. Amplatz.

"Homodynamic assessment of obstructive aprtoiliac discase." 
Am. J. Roentgenol. voll 127, 1976, pp 559-561

D. Charlesworth, P.L. Harris, F.D. Cawe, L. Taylor

"Undetected aortoiliac insufficiency: a reason for carly failure of saphenous wein bypass grafts for obstruction of the superficial femoral artery. "Br. J. Surg. vol 62, 1975, pp $567-570$

P.M. Chikos, L.D. Fisher, J.H. Hirsch, J.D. Harley, B.L. Thiele, D.E. Strandness jr.

"Observer variability in evaluationg extracraniall carotid artery stenosis."

Stroke vol 14 nr. 6,1983, pp $885 \times 892$

C. Clark

"The propagation of turbulence produced by a stenosis." J. Biomechanics vol 13, 1980, pp 591-604

P.C. Clifford, R, Skidmore, D.R.Bird, J.P. Woodeock, R.N. Baird

"The role of pulsatility index in the clinical assessment of lower limb ischaemia."

J. of Med. Engng. \& Technol. woll $5 \mathrm{nr}$. 5, sept 1981, pp 237.243

B.A. Coghlan, M.G. Taylor

"On methods for preprocessing direction Doppler signals to allow display of directional blood velocity waveforms by spectrum analysers."

Med. \& Bioll. Eng. \& Comput. vol 16, sept 1978, pp 549-553

J.D. Colt

"New Doppler pressure indexes plotted as curwes." Am. J. of Surg. vol 136 1978, pp 198-201

M. Cornette, O. Grosjean

" Diagnostic des lésions de l'étage aonoialique par l'examen Doppler couplé une épreuwe d'hyperhémie."

Revue medical de Liège vol $37 \mathrm{nr} .2,1982$ pp $37-47$

A.D. Craxford, J. Chamberlain

"Pulse wave form transit ratios in the assessment of peripheral vascular disease."

Br. J. Surg. vol 641977 , pp $449-452$

E.S. Crawford, R.A. Bomberger, D.H. Glaeser, S.A. Saleh, W.L. Russel

"Aortoiliac occlusive disease: factors influencing surwival and function following reconstructiwe operation over a twenty-five period." Surgery vol 90 nr. 6 dee 1981, pp 1055-1065

D. Demora is, K.W. Johnston

"Assessment of aortoiliac disease by non-invasive quantitative Doppler waveforrn analysis."

Br. J. Surg. vol 68 1981, pp 789-792

D.H. Evans, W.W. Barrie, M.J. Asher, S. Bentlley, P.R.F. Betl

"The relationship between ultrasonic pulsatility index and proximal arterial stenosis in a canine model."

Circ. research vol 46 april $1980 \mathrm{nr} 4 \mathrm{pp} 470-475$

D.H. Evans, D.S. Macpherson, M.J. Asher, S. Bentley, P.R.F. Bell

"The effect of proximal stenosis on Doppler waveforms: a comparison of three methods of waveform analysis in an animal model." Clin. Phys. Physiol. Meas.vol 2 nr.1, 1981, pp 17-25

D.H. Evans, D.S. Macpherson, M.J. Asher, S. Bentley, P.R.F. Bell

"Changes in Doppler ultrasound sonograms at varying distances from stenoses"

Cardiovasc. Research 1982, 16, pp 631-636

I. Faris, K.H. Tonnesen, K. Agerskov, I. Noer, P.Sager

"Femoral artery pressure measurements to predict the outcome of arterial surgery in patients with multilevel disease." Surgery, vol 92, nri, july 1982, pp 10-15

W.R. Felix, B. Siegell, G. Popky

"Doppler ultrasound in the diagnosis of peripheral vascular discase."

Seminars in roentgenology vol 10, now 1975 , pp 315-321

D.P. Flanigan, B. Gray, J.J. Schuller, J.A. Schwarts, K.W. Post

"Correlation of Doppler derived high thigh pressure and intra arterial pressure in the assessment of aortoiliac occlusive disease." Br. J. Surrg. vol 68, 1981, pp 423-425

D.P. Flanigan, T.J. Ryan, L.R. Willaams, J.A. Schwarz, B. Gray, J.J. Schuler

"Aoriofemoral or femoropopliteal revascularisation? a prospective evaluation of the papaverine test."

J. of Vasc. Surg. vol 1, 1984, pp 215-223

D.P. Flanigan, J.J. Schuler, D.G. Spigos, L. T. Lim

"Antatomic and hemodynamic evaluation of percutaneous transluminal angioplasty."

S.G.O. vol 154, febr. 1982, pp 181-185

D.P. Flanigan, J.P. Tullis, V.L. Sitreeter, W.M. Whitehouse, W.J. Fry, J.C. Stanley 
"Multiple subcritical aruerial stenosis: effect on poststenotic pressure and flow."

Antals of Streg woll 186,1977 , pp 663-668

D. P. Flanigan, L.R. Willams, J. A. Schwarz, II. S. Schuler, B. Gray

"Hemodyramic ewaluation of the aonoiliac system based on pharmacologic vasodilation."

Surgery wol 93 nr 5 , may 1983, pp 709-714

D.L. Franklin, W. Schlegel, R.F. Rughmer

"Blood Ilow measured by Doppler frequency shift of back-scaitered ultrasound."

Science woll 134, 1961, pp $564-565$

A. Fronek, M. Cod, E.F. Bernstein

"The importance of combined multisegmental pressure and Doppler flow velocity studies in the diagnosis of peripheral artcrial occlusive discase."

Surgery wol 84 nir. 6 , december 1978 , pp $840-845$

R.B. Galland, D.A. Hill, R. Gustave, CW Jamieson

"The functiondl results of aontoiliac reconstruction." Br. J. Surg. wol 67, 1980, pp 344-346

R.G. Gosling

"Extraction of physiological information from spectrum analysed Doppler shifted continuous wave wlirasound signals obtained non invasively from the arterial system.

In 1.E.E. Modical Elcctrionics Monograph (Eds Hill and Watson) Peter Peregrinus, Stevenage 1976, pp $73-121$

R.G. Gosling, G. Dumbar, D.H. King, D.L. Newman, C.D. Side, J.P. Woodcock, D.E. Fitzgerald, I.S. Keates, D. Macmillan

"The quantitative analysis of occlusive peripheral ancrial discase by a non intrusive ultrasonic technique." Angiology vol 22, 1971, pp $52-55$

R.G. Gosling, D.H. King

"Arterial assessment by Doppler shift tutuasound."

Proc. Royal Soc, of Medicine vol 67, 1974, pp 447-449

R.G. Gosling, D.H. King

"Continuous wawe ultrasound as an alternative and complement to $\mathrm{X}$-rays in vascular examinations." in: cardiovascular applications of ultrasound. eds R.S. Reneman North Holland publishing, Amsterdam 1974, pp $266-282$

L. Haeck, J. Vam Baalen, J. Buth

"Upstrearn stenosis: its diagnosis by spectral analy sis of Doppler signals from femoral and iliac arteries."

The Netherl. J. Surg. vol $35 \mathrm{nr} 3,1983, \mathrm{pp} 111$

H. Haimovici

"Patlens of arteriosclerolic lesions of the lower extremity."

Arch. Surg. vol 95, dec 1967 pp 918-933

C.P. Holford, S. Laing, R.M. Greenhalgh

"Evidence that simple non invasive evaluation augments clinical and radiological assessment of peripheral arterial disease." in Diagnosis and Monitoring in arterial surgery edt R.N. Bard and J.P. Woodcock, J.

Wright Bristol 1980, pp $11-20$

P.L. Harris, L. A. Taylor, F.D. Cave, C. Charlesworth

"The reliationship between Doppler ul trasound assessment and angiography in occlusive artierial disease of whe lower limbs:" S.G. O. vol 138, june 1974, pp $911-914$

T.R.S. Harward, E.F. Bernstein, A. Fronck

"The valuc of powert frequency spectrum anallysis in the identification of aortoiliac artery disease." J.

Vasce. Surg vol 5 nr 6, june 1987, pp $80 \times 83$

S.E. Heinti, G.E. Bone, E.E. Slaymaker, A.C. Hayes, R.W. Bames

"Value of arterial pressure measurcments in the proximal and distal part of the thigh in arterial occlusive discase." S. G. O. vol 146, march 1978, pp 337-343

S.W. Flax, J,O. Webster, S,J. Updike

"Pilfialls using Doppler ultrasound to transduce blood flow."

LEEE ransactions on biomedical engineering, july 1973, pp 306-309

M. Hennerici, A. Aullich, W. Sandmann, H.J. Freund

"Incidence of asymptomatic ex tracranial arierial discase."

Stroke yol 12 nr. 6, nov-dec 1981, pp 750-758 
A.P.G. Hoeks, C.J. Ruisen, P.Hick, R.S. Reneman

"Transcutaneous detection of relative changes in artery diameter."

Ultras. Med. \& Biol. vol $11 \mathrm{mr} .1,1985$ pp $51-59$

K.N. Humphries, T.R. Hames, S.W.J. Smith, V.A. Cannon, A.D.B. Chant

"Quantitative assessment of the common femoral to popliteal arterial segment using continuous wave Doppler ultrasound." Ultrasound in Med. \& Biol. vol 6, 1980, pp 99-105

T. Itoh, M. Hori

"Vascular endoscopy for major vascular teconstnuction: experimental and clinical studies."

Surgery vol 93 nr. 3, march 1983 , pp 391-396

H.T. Iohn, R. Warren

"The stimulus to collateral circulation" Surgery vol 49, 1961, pp 14-25

K.W. Johnston

"Role of Doppler ultrasonography in determining the hemodynamic significance of aortoiliac disease."

The Canadian J. Surg. vol $21 \mathrm{nr}, 4$, jully 1978, pp 319-321

K.W. Johnston, M. Kassam, R.S.C. Cobbold

"Relationship between Doppler pulsatility index and direct femoral pressure measurements in the diagnosis of aortoiliac occlusive discase."

Ultrasound in Med. \& Biol. vol 9 nr. 3 1983, pp 271-283

K.W. Johnston, B.C. Maruzzo, R.S.C. Cobbold

"Errors and artifacts of Doppler flowmeters and their solution. "

Arch. Surg. vol 112, nov 1977, pp 1335-1342

K.W. Johnston, M. Kassam, J. Koers. R.S.C. Cobbold, D. Machattie

"Comparative study of four methods for quantifying Doppler ultrasound waveforms from the femoral artery." Ultrasound in Med. \& Biol. vol 10, nrl 1984, pp 1-12

K.W. Johnston, M. Kassam, R.S.C. Cobbold

"Online identifying and quantifying Doppler ultrasound waveforms."

Med. \& Biol. Eng \& Comput. vol 20, 1982, pp 336-342

K.W. Johnston, D. Demorais, R.F. Colapinto

"Difficulty in assessing the severity of aortoiliac disease by clinical and anteriographic methods"

Angiology vol 32, 1981, pp 609-614

J.J.Jorgenson, E. Stranden, T. Gjolberg

"The femoral arterial flow velocity pattern in patients with aortoiliac atherosclerosis."

Acta Chir. Scand. vol 152, 1986, pp 257-281

M. Junger, B.L.W. Chapman, C.J. Underwood, D. Charlesworth

"A comparison between two types of waveform analysis in patients with multisegmental arteriall disease."

Br. J. Surg. vol 71 , may 1984 , pp 345-348

J. Kaneko, J. Shiraishi, H. Omizo, H. Inaoka, T. Ueshima

"Analysis of ultrasonic bliood theogram by the sound spectrograph."

Japanese circulation journal vol 34, now 1970, pp 1035-1045

K. Kato, Y. Kido, M. Motomiya, Z. Kaneko, H. Kotani

"On the mechanism of generation of detected sound in ultrasonic flowmeter."

Memoirs of the insitute of scientific and industrial research Osaka wol 19, 1962, pp 51.57

W.F. Keitzer, W.J. Fry, R.O. Kraft, M.S. DeWeese, H.E.Sloan

"Hemodynamic mechanism for pulse changes seen in occclusive vascular disease."

Surgery vol 57 nr 1, jan 1965, pp 163-174

P.J.E.H.M. Kitslaar

"Bloeddrukmeting aan de enkel bij obstruerend vaatijiden."

Ned. T. Geneesk. vol 125 nr. 44, 198 I pp 1781-1785

P.J.E.H.M. Kitslaar

"Doppler ultrasound tests in the diagnosis of chronic aortoiliac obstruction." thesis, Maastrich 1982

P.J.E.H.M. Kitslaar, P.J.G. Jörning, J.P.F.M., Koklen

"Assessment of aontoiliac stenosis by femoral artery pressure measurement and Doppler waveform analysis."

Eur. J. Vasc. Surg. 2, 1988, pp 35-40

T. R. Kohler, S.C. Nicholls, R.E. Zierler, K.W. Beach, P.J. Schubart, D.E. Strandness jr, 
"Assuessment of pressume gradickit by Doppler ultrasound: experimental and chinical observations."

I. Vasce. Surge vol 6 ar. 5,1987, pp $460-469$

D.N. Ku, D.P. Giddens, D.J. Phillips, D.E. Strandness jr.

"Hemodynamics of the normal human carotid bifurcation: in witro and in vivo studies."

Ultrasound in Med. B Bol, vol 11 nir. 1, 1985, pp 13-26

Q.H.M. Landmam

"First experiences with a new installation for angiography."

Mcdicamandi voll $23 \mathrm{nr} 3,1978$, pp $137-145$

E. K. Lang, J. Foreman, J.U. Schlegel, C. Leslie, A. List, P. Mc Cormick

"The incidence of contrast medium induced $\mathrm{A} T \mathrm{TN}$ following angiography."

Rexdiology wol $138,1981, \mathrm{pp} 203$

M. Langsfeld, J. Nepute, F.B. Hershey, L. Thorpe, A.I. Auer, H.B. Binnington, J.J. Hurley, G.J.

Peterson, R. Schwarz, J.J. Woods jr.

"The use of decp duplex scanning to predict hemodynamically significant aortoiliac stenoses."

J. Vase. Surge vol 7, 1988, pp 395-399

A.J. Lasalle, D.C. Brewster, J.D. Carson, R.C. Darling

"Femoropopliteal composite bypass grafts: current state."

surgery vol 92 nr. 1 , july 1982 . pp $36-39$

B.Y Lee, M.T. Castillo, J.L. Madden

"Quantification of the arterial pulsatile blood flow waveform in peripheral vascular discase."

Angiology vol 21, 1970, pp 595-605

S.H. Levenson, P.J. Guillou, HJ. Terry, J.N. Glanwille, R.C. Kester

"Pulse pressure wave analysis in the diagnosis of aortoiliac disease."

Ann. Surg. vol 187 nr. 2, 1978, pp 161-165

R.E. Lind, C.B. Wright, T.G. Lynch, W.C. Lamberth, E.E. Slaymaker, B. Brandt

"Aortolemoral bypass grafting." The Annerican surgeon, vol 48, march 1982, pp $89-92$

E. Lorentson, B.lL. Hoel, R. Hol

"Evaluation of the functional importance of atheroselerotic obliteration in the aonoiliac antery by pressure/Ilow measurements." Acta Med. Scand. vol 191, 1972, pp 399-403

M.J. Lunt

"Accuracy and limitations of the ultrasonic Doppler blood velocimeter and zero crossing detechor."

Ultrasound in Med. \& Biol. vol 2, 1975, pp 1-10

P.C. Macpherson, S.J. Mcldrum, D.S. Turnstall-Pedoe

"Angiosean: a spectrum analyser for the use with ultrasonic Doppler velocimeters."

Journ. of Med. Engeneering \& Techn, vol 5, nr.2 march 1981, pp 84-85

D.S. Macpherson, D.H. Evans P.R.F. Bell

"Common femoral artery Doppler waveforms: a comparison of three methods of objective analysis with direct pressure measurements." Br. J. Surg. vol 71, jan 1984, pp 46-49

A. G. May, L. Van de Berg, J. A. DeWeese, C.G. Rob

"Critical arterial stenosis" Surgery vol 54, 1963, pp 250-259

A.C. May, J.A. DoWeese, CG. Rob

"Hemodynamic effects of anterial stenosis." Surgery wol 53, 1963, pp 513-524

T. van Merode, J. Lodder, F.A.M. Smeets, A.P.G. Hocks, R. ${ }_{\text {S. }}$. Reneman

"An accurate non-inwasive method to diagnose minor atherosclenotic lesions in the carotid artery bulb."

Suroke - in press

R.D. Miles, H.S. Bada, D.S. Sumner, D.J. Moore, M.B. Schneider

"The Doppler pulsntility index and its relation to pressure, flow, resistance and angle."

Bruit vol 8, dec 1984, pp 274-278

D.A. McDonald

"Blood llow in arteries" London, eds. Edward Arnold 2nd edition 1974

B.I. McNeil, E. Keeler, S.J. Adelstein

"Primer on certain elements of medical decision making."

N. Engl. J. Med. vol 293, july 1975, pp 2/1-215

W.S. Moore. A.D. Hall

"Unrecognised aortoiliac stenosis, a physiological approach to the diagnosis." 
Arch. Surg. vol 103, nov 1971, pp 633-638

K. Moritake, H. Handa, $\mathbb{I}$. Nagata, Y. Takebe, A. Okumura

"Experimental sudy on quantitative flow measurement by a Doppler flowmeter with a sound

spectrograph." Neurol. research wol 3 nr.4, 1981, pp 363-380

K.A. Meyers, D.F. Scott, T.J.Devine, A. H. Johnston, M.J. Denton, L.S. Gilfillan

"Palpation of the ffemoral and popliteal pulses: a study of the accuracy as assessed by agreement between multiple observers." Eur. J. Vasc. Surg. vol 1, 1987, pp 245-249

A. Nevelsteen , R. Suy, W. Daenen, A. Boel, G. Stalpaert

"Aortofemoral grafting: factors influtencing late results."

Surgery wol $88 \mathrm{nr} .5,1980$, pp 642-652

S.C. Nicholls, T. R. Kohler, R.L. Martin, R. Neff, DuJ. Phillips, D.E. Strandness jr.

"Diastolic flow as a predictor of arterial stenosis."

J. Vasc. Surg. vol 3 nr. 3, march 1986, pp 498-501

A.N. Nicollaïdes, I.C. Gordon-Smith, J.Dayandas, H.H.G. Eastcont

"The value of Doppler blood velocity tracings in the detection of aortoiliac disease in patients with intermituent claudication." Surgery vol $80 \mathrm{nr} .6$, dec 76. pp 774-778

Y. Nimuta, H. Matsuo, T. Hayashi, A. Kitabatake, S. Mochizuki, H. Sakakibara, K. Kato, H. Abe

"Studies on arterial flow patterns - instantaneous velocity spectrums and their phasic changes with

directional ultrasonic Doppler technique." Br. Heart J. wol 36, 1974, pp 899.907

A. Nowicki. P. Karlowicz, M. Piechocki, W. Seconski

"Method for the measurement of the maximum Doppler frequency."

Ultrasound in Med. \& Biol. vol $11 \mathrm{mr}$. 3, 1985, pp 479-486

P.A. Peronneau, J. Hinglais, M. Pellet, F. Léger

"Vélocimètre sanguin par effet Doppler à émission ultra-sonore pulsée."

L' onde électrique vol 50, 1970, pp 369-384

A. Y. Persson, G. Gibbons, S. Griffey

"Noninvasive evaluation of the aortoiliac segment."

J. Cardiovasc. Surg. vol 22, 1981, pp 539-542

J. Petermans, M. Zicot

"Eude des axes antériels iliaques par ultrasonographie Doppler lons de l'hyperémie provoquće par la marche et par l'occlusion artérielle."

J. des Maladies Vasc. Paris vol 8. 1983, pp 245-247

R.Q. Quin, D.H. Evans, P.R.F. Bell

"Hemodynamic assessment of the aortoiliac segment." J. Cardiovasc. Surg. vol 16, 1975 pp 586-589

D.J. Reddy, G.S. Vincent, M. McPharlin, C.B. Ernst

"Limitations of the femoral artery pulsatility index with aortoiliac artery stenosis: an experimental study."

J. Vasc. Surg. vol 4 nr. 4, 1986, pp 327-332

N.C. Reidy, R. Walden, W.A. Abott, A.J, Greenfield, G. L'Italien, J. Megerman

"Anatomic localization of atherosclerotic lesions by hemodynamic tests."

Arch. Surg. vol 116 aug. 1981, pp 1041-1044

R.S. Reneman, A.P.G. Hoeks

"Doppler Ultrasound in the diagnosis of cerebrovascular disease" eds. Ressearch Studies Press 1982 Joln

Willey \& Sons

R.S. Reneman, M.P. Spencer

"Local Doppler audio spectra in normal and stenosed carotid arteries in man."

Uitrasound in Med. \& Biol. vol 5, nr. 1 1979, pp 1-11

R.S. Reneman, A. Hoeks, M.P. Spencer

"Doppler ultrasound in the evaluation of the peripheral arterial circulation."

Angiology vol 30, 1979, pp 526-537

R.S. Reneman

"Fysiologie en pathofysiologie van de arterièle circulatic van de onderste ledematen."

Tijdschr. voor Geneask. 14 - 33 jg. 1977, pp 773-781

R.S. Reneman, H. F. Clarke, N. Simmons, M.P. Spencer

"In vivo comparison of ultramagnetic and Doppler flowmeters: with special attention to the processing of the analogue Doppler flows signal." 
Cardioviasc. research vol 7,1973 , pp $\$ 57.566$

R. S. Renteman. T. wan Merode, P. Hick, A.P.G. Hoeks

"Fow welocity patuerms in and distensibitity of the carotid bulb in subjects of various ages."

Circulation vol 71 nr. 3, 1985, pp 500-509

R.S. Reneman, T. wan Merode, P. Hick, A.P.G. Hoeks

"Cardiovaseular applications of multigate pullsed Doppler systems."

Ultrasound in Mod. B Biol. woll $12 \mathrm{nr} .5,1986$, pp $357-370$

R.S. Reneman

"What measurements are necessary for a comprehengive ewaluation of the peripheral arterial circulation."

Cardiovasc dis. bulletin of the Texas Heart Inst. vol 8 nr. 3, sept 1981, pp 435-454

J. V. Richardson, E. E. Slaymaker, C.B. Wright

"Distal reconistruction following aontobifemoral bypass grafting: predictability by early hemodynamic results." The American Surgeon vol $46 \mathrm{nr}$. 9, sept 1980, pp $477-480$

R. Ross

"Atherosclerosis: a problem of the biology of arterial wall cells and their interactions with blood components." Aftcriosclerosis vol 1, 1981 pp 293-311

A.J. Saintz V.C. Roberts

"Signal to noise enhancement in Doppler ultrasound systems."

Med. \& Biol. Eng \& Comput. vol 19, 1981, pp 665-667

Y. Sako

"Papaverine test in peripheral arterial disease." Surgical Forum vol 17, 1966 pp 141-143.

B. Satiani, J.P. Hayes, W.E. Evans

"Prediction of distal reconstruction following aortofiemoral bypass for limb salvage."

S.G O. wol 151, oct. 1980 pp $500-502$

B. Satiani, C. Hou, D. Paoleti, M. Henry, R. Burns, D. Smith

"Non invasive assessment of aortoiliac disease." Bruit wol 9, april 1985 PP 29-33

G.K. Sethi, S.M. Scott, T. Takaro

"Mulciple-plane angiography for more precise evaluation of aortoilliac disease."

Surg. vol 78 nr. 2, aug. 1975 pp 154-159

R.D. Schultz, D.E. Hokanson, D.E. Strandness jr.

"Pressure-flow and stress-strain measurements of normal and diseased aortoiliac segments."

S.G.O. june 1967 pp 1267-1276

W.H. She hadil, G. Tionido

"Adverse teactions to contrast media." Radiology vol. 137, 1980, pp 299

W.H. Shehadi

"Contrast media adverse reactions and occurence, recurrence and distribuiion pattems."

Radiology wol 143, 1982 pp 11

S.B. Sherriff, D.C. Barber, T.R.P. Martin, J.M. Lakeman

"Use of principal component factor analysis in the detection of carotid artery disease from Doppler ultrasound." Med. Biol. Eng. \& Comput. vol 20, 1982, pp 351-356

H. Simon, J.T. Fairbank

"Biplane transiumbar aortography for evaluation of peripheral vascular disease."

The Atn. J. of Surgery vol 133, april 1977, pp 447-452

R. Skidmore, J.P. Woodcock

"Physiological interpretation of Doppler shift waveforms - I - II - III"

Ultrasound in Med. \& Biol. wol 6, 1980, pp 7-10, pp 219 - 231

R. H. Smalliwood, B.H. Brown

"A measure of blood flow from a frequency analysed ultrasonic Doppler signal."

J. of Med. Eng. and Texhnol. vol 2 or. 2, march 1978, pp 73-74

R.K. Spence, D.B. Freiman, R. Gatenby, C.L. Hobbs, C.F. Barker, H.D. Berkowitz, B. Roberts, G.

McClean, J. Oleaga, E.J. Ring

"Long-term results of transluminal angioplasty of the iliac and femoral arteries."

Arch. Surg. vol 116 , nov 1981, pp 1377-1386

M.P. Spencer, T*, Arts

"Hemodynamic principles for cardiac Doppler diagnosis." in Cardiac Doppler diagnosis, vol I Martinus 
Nyhoff publishers 1984 edt by M.P. Spencer pp 131-141

M.P. Spencer, L.H. Edmunds ji.

"Evaluation of operative left ventricular outflow tract lesions with a fluid impedance plot."

Circulation vol 37, june 1968, pp 912-920

M.P. Spencer, J.M. Reid

"Quantitation of carotid stenosis with CW Doppler ultrasound."

Stroke vol $10 \mathrm{nr} .3,1979 \mathrm{pp} \mathrm{326-330}$

D.E. Strandness j $\mathrm{r}_{\mathrm{u}}$ R.D. Schultz, D.S.Sumner, R.F. Rushmer

"Ultrasonic flow detection - A useful technic in the evaluation of peripheral vascular disease."

Am. J. of Surgery voll 113, march 1967, pp 311-320

D.E. Strandness jr.

"Doppler ultrasonic techniques in vascular disease" in Noninwasive diagnostic techniques in vascular disease.

edt by E.F. Bernstein - third edition , 1985 - The Mosby Company

D.S. Sumneir

"Hemodynamics and pathophysiology of arterial disease"

in Vascular Surgery - R.B. Rutherford - 2 nd cd. W.B. Saunders 1984, pp 19-45

D.S. Sum ner, D.E. Strandness jr.

"Aortoiliac reconstruction in paticnts with combined iliac and superficial femoral arterial occlusion."

Surgery vol 84 nt. 3, sept 1978 , pp $348-355$

D.F. Switzer, N.C. Nanda

"Doppler color flow mapping." Ultras. in Med. \& Biol. wol $11 \mathrm{nr} .3,1985$, pp 403-416

B.L. "Thiele, D.F. Bandyk, R.E. Zierler, D.E. Strandness jr.

"A systemic approach to the assessment of aortoiliac disease."

Arch. Surg. voll 118 , april 1983 pp $477-481$

M.L. Thomas M.R. Andress

"Value of oblique projections in translumbar aortography."

Am. J. Röntgenol, wol 116 nr. 1, 1972, pp 187-193

E.J. Udoff, K.H. Barth, D.P. Harrington, S.L. Kaufman, R.I. White

"Hemodynamic significance of iliac artery stenosis: pressure measurements during angiography."

Radiology woll 132, aug. 1979, pp 289-293

P. F. Verhagen

"Post-ischemic reactiwe hyperemia in the diagnosis of peripheral arterial obstructive disease."

thesis Rotterdam 1985

P.F. Verhagen, T.J. M.V. Van Vroonhoven, S. Skotnicki

"Femoral artery pressure criteria in the assessment of the aortoiliac segment obtained by means of a receiver operator characteristic curve analysis."

the Netherl. J. of Surg. vol 39 nr. 4, 1987, pp 115-117

P.F. Verhagen, T.J.M.V. Van Vroonhoven

"Criteria from intra arterial femoral artery pressure measurements combined with reactive hyperemia to assess the aortoiliac segment; a prospective study."

Br. J. Surg. vol 71, sept 1984, pp 706-708

A. Vermeulen

"Endocriene ziekten en stof wisselingszickten" edn Story-Scientia Gent 1974 pp 407

L. Walton, T.R.P. Martin, M. Collims

"Prospective assessment of the aontoiliac segment by visual interpretation of frequency analysed Doppler waveforms. A comparison with anteriography."

Ultrasonic in Med. \& Biol. vol $10 \mathrm{nr} .1,1984, \mathrm{pp} 27-32$

A.S. Ward

"Reactive hyperaemia recovery time, pulsatility index and transit time in the diagnosis of the aontoiliac disease." Diagnosis and Monitoring in arterial surgery edt R.N. Bard and J.P. Woodcock, J. Wright

Bristol 1980, pp 103-113.

A.S. Ward, T.P. Martin

"Some aspects of ultrasound in the diagnosis and assessment of aortoiliac disease."

The Am. J. of Surg. vol 140, aug. 1980, pp 260-265 
K.J. Waters, J. Chamberlain

"The assessment of aortolliac disease, using non dirctional Doppller ultrasownd and the effect of arterial reconstuction," in: Diagnosis and Monitoring in arterial surgery edt R.N. Band and J.P. Woodcock, J.

Wright Bristol 1980, pp115-119.

R.E. Weismann, J.F. Upsen

"Intra arterial pressure studies in patients with artcrial insufficiency of lower extremities."

Annal of Sargery vol 157, 1963, pp 501-506

P.N.T. Wells

"The medical application of wltrasonics." in : Cardiowascular applications of ultrasound. ed. R.S.

Reneman North Hollland pubtishing Arnsterdam 1974

I.P. Woodeock, R. Gosling, D.E. Fiugerald

"A new non invasive tecthique for assessment of superficial femoral artery obstruction."

Brit. J. Surg. vol 59 nr. 3, march 1972, pp 226-231

M. Zilicot

"Assessment of occlusive proximal arterial disease in the lower limbs by simple non invasive methods."

Vasa band 11 heft 2, 1982, pp86-90 


\section{NASGHRUFT}

Bij het tot stand komen van dit onderzoek zijn zeer veel mensen betrokken geweest. Om niemand te vergeten dank ik hierbij allen.

Het onderzoek werd verricht in een aangename sfeer tijdens mijn chirurgische opleiding in het Catharina-Ziekenhuis (Eindhoven). Het werd gestimuleerd door de chirurgen, met name Dr. J. Buth, Dr. J.J. Jakimowicz, Dr. J.M.M.P.H. Herman en vooral door de opleider Dr. J.G. Prins.

Dank ook aan het radiologische team dat instond voor de fraaie arteriografieën, Dr. G.H.M. Landmann en voor de correcte drukmetingen, H. De Vries.

A. Muytjens van de afdeling Medische Informatica en Statistiek Rijksuniversiteit Limburg dank ik voor zijn bereidwillige verwerking der gegevens.

Mijn erkenning gaat echter tot slot naar Prof. Dr. R.S. Reneman en Dr. A.P.G. Hoeks die mij continue stimuleerden het onderzoek niet enkel te verrichten maar ook te verwerken, en daarbij een beter en dieper inzicht te verwerven in de arteriële hemodynamiek. De reisjes naar Maastricht namen in frequentie toe en iedere keer kwam $\mathrm{ik}$ terug vol enthousiasme.

Tot slot dank ik mijn echtgenote voor haar eindeloos geduld. 


\section{CHPRACULAM WRAE}

Luc B. A. Hack werd geboren op 17 augustus 1952 te Tielt, België Na zijn hunianiorastudies aan het Sint-Jozefscollege te Tielt, begon hij in 1970 de medische studie wan de Rijksuniversiteit te Gent, België. Het diploma van docter in de genees-, heet-, en verloskunde werd behaald in juli 1977.

De opleiding chirurgie werd begonnen in augustus 1977 in het O.-L.-Vrouw Ziekenhuis te Waregem, België onder leiding van Dr. A.L. Bouckaert. De opleiding werd voorgezet van augustus 1980 tot augustus 1984 in het Catharina-Ziekenhuis te Eind howen, Nederland, onder leiding van Dr. J.G. Prins. Het onderzoek dat tot dit proelschrift leidde werd tijdens deze opleiding verricht.

Hij werd in 1983 ingeschreven in het Belgisch specialistenregister.

Sinds augustus 1984 is hij als chirurg full-time verbonden aan het O.-L.- Vrouw Ziekenhuis te Waregem, België. 